\title{
VALORACIÓN DOGMÁTICA DEL CONCEPTO COMBATIENTE EN EL CONFLICTO ARMADO COLOMBIANO
}

TRABAJO PARA OPTAR EL TÍTULO DE MAGISTER EN DEFENSA DE LOS DERECHOS HUMANOS Y EL DERECHO INTERNACIONAL HUMANITARIO ANTE TRIBUNALES Y CORTES INTERNACIONALES

\author{
CRISTIAN JAVIER MARÍN TOVAR
}

\section{UNIVERSIDAD SANTO TOMÁS}

FACULTAD DE DERECHO

MAESTRÍA EN DEFENSA DE LOS DERECHOS HUMANOS Y EL DERECHO INTERNACIONAL HUMANITARIO ANTE TRIBUNALES Y CORTES INTERNACIONALES BOGOTÁ D.C. 2016 


\title{
VALORACIÓN DOGMÁTICA DEL CONCEPTO COMBATIENTE EN EL CONFLICTO ARMADO COLOMBIANO
}

\author{
CRISTIAN JAVIER MARÍN TOVAR
}

Director:

DR. LUIS MANUEL CASTRO NOVOA

UNIVERSIDAD SANTO TOMAS

FACULTAD DE DERECHO

MAESTRÍA EN DEFENSA DE LOS DERECHOS HUMANOS Y EL DERECHO INTERNACIONAL HUMANITARIO ANTE TRIBUNALES Y CORTES INTERNACIONALES

BOGOTÁ D.C. 2016 


\section{TABLA DE CONTENIDO}

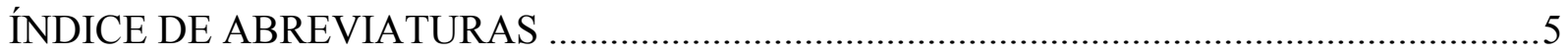

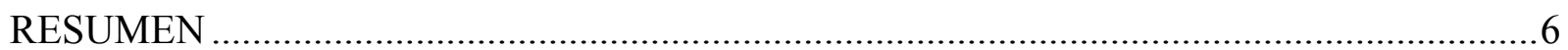

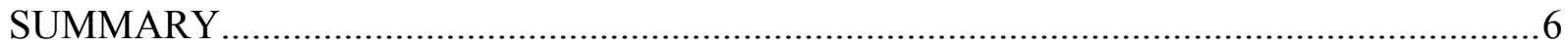

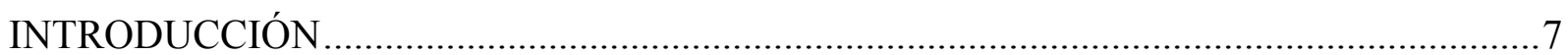

1. COMBATIENTE, ANÁLISIS DE SU ROL EN LOS DIVERSOS CONFLICTOS

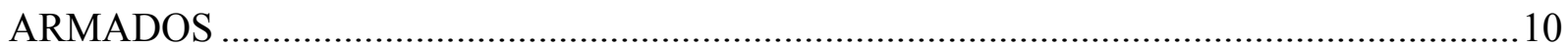

1.1. El combatiente en los Conflictos Armados Internacionales (CAI) ....................................13

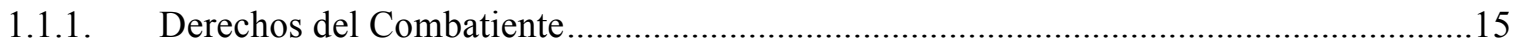

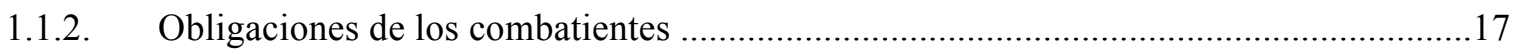

1.2. El combatiente en los conflictos armados no internacionales CANI ...................................19

1.2.1. Los civiles que participan directamente en las hostilidades ..........................................23

1.2.2. Los civiles que participan indirectamente en las hostilidades ........................................30

2. CONFLICTO ARMADO COLOMBIANO, MODOS Y MÉTODOS ASIMÉTRICOS PARA DESARROLLAR LA CONFRONTACIÓN ARMADA ………………………............31

2.1. Elementos esenciales para la denominación del conflicto armado.........................................32

2.1.1. Conflicto Armado en las decisiones de los órganos que materializan el Ius puniendi a nivel interno

2.1.2. Denominación del conflicto armado en los pronunciamientos de los Tribunales

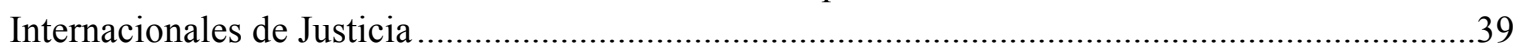

2.2. El papel del combatiente de cara a los principios del DIH...................................................44

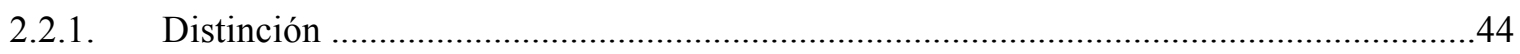

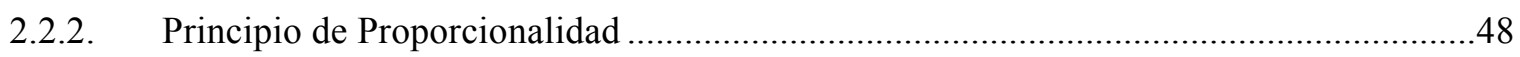

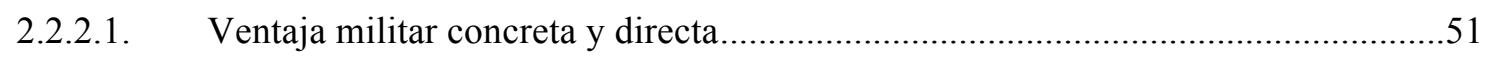

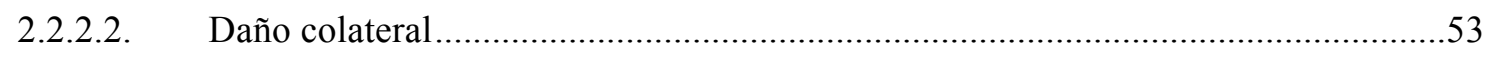

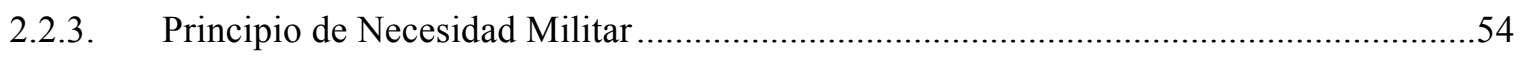

2.3. Modos y métodos asimétricos en el contexto del conflicto armado colombiano....................58

2.3.1. Menores de edad utilizados por los GAO en la guerra asimétrica ................................59

2.3.2. Artefactos explosivos improvisados herramienta asimétrica de guerra .........................64

2.3.3. El secuestro estrategia asimetría de financiación ...........................................................68

3. ANÁLISIS DEL USO DE LA FUERZA DESDE LA PERSPECTIVA PENAL EN LOS CANI, UN PROBLEMA DE TIPICIDAD EN EL CONTEXTO COLOMBIANO..................71

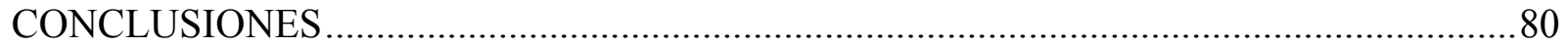

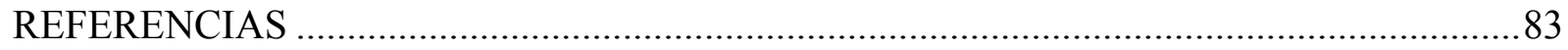


Nota de aceptación:

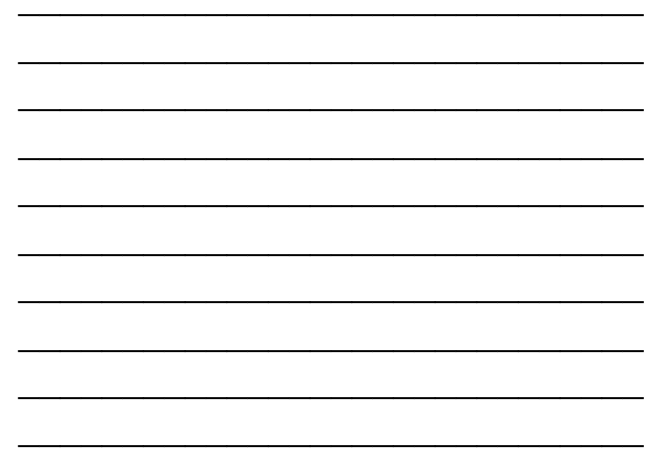

Firma del Jurado

Bogotá D.C. junio de 2017 


\section{ÍNDICE DE ABREVIATURAS}

AEI. Artefactos Explosivos Improvisados

AUC. $\quad$ Autodefensas Unidas de Colombia

CAI. Conflicto Armado Internacional

CANI. Conflicto Armado no Internacional

CICR. Comité Internacional de la Cruz Roja

CIDH. Corte Interamericana de Derechos Humanos

CPI. Corte Penal Internacional

CTI. Cuerpo Técnico de Investigación de la Fiscalía

DIDH. Derecho Internacional de los Derechos Humanos

DIH. Derecho Internacional Humanitario

ELN. Ejército de Liberación Nacional

FARC. Fuerzas Armadas Revolucionarias de Colombia

GAO. Grupo Armado Organizado

OEA Organización de Estados Americanos

ONU Organización de las Naciones Unidas

TPIR. Tribunal Penal Internacional para Ruanda

TPIY. Tribunal Penal Internacional para la antigua Yugoslavia 


\section{RESUMEN}

El tema que ocupa el presente trabajo, está orientado a determinar el papel del combatiente en el conflicto armado, el marco jurídico aplicable desde la perspectiva del derecho a la guerra y la especial característica que reviste el caso colombiano desde la representación de la caracterización de la asimétrica de la confrontación armada, en torno a los modos y métodos de lucha utilizados por los grupos armados para alcanzar los objetivos de la organización.

Se busca interpretar los instrumentos compilados en el derecho internacional, para entender el papel del combatiente en el desarrollo de las hostilidades, con el fin de resaltar la dificultad que existe a la hora de cumplir la función, cuando el operador judicial que analiza el caso aplica el marco jurídico inadecuado, interpreta el contexto de los acontecimientos con un enfoque diferencial y desarrolla su actuación sin contar con las especificidades que trae inmerso el día a día militar, el derecho operacional y el derecho internacional humanitario.

Palabras clave: Asimetría, conflicto armado, combatiente, operacional, confrontación armada.

\section{SUMMARY}

The subject of this work is aimed at determining the role of the combatant in the armed conflict, the legal framework applicable from the perspective of the right to war and the special characteristic that is present in the Colombian case from the representation of the characterization of The asymmetric Armed confrontation, around the methods and methods of struggle used by armed groups to achieve the objectives of the organization.

It seeks to interpret the instruments compiled in international right, to understand the role of the combatant in the development of hostilities, in order to highlight the difficulty in fulfilling the function, when the judicial operator that analyzes the case applies The inadequate legal framework, interprets the context of events with a differential approach and develops its action without the specifics that are involved in the day-to-day military, operational law and international humanitarian law.

Key words: Asymmetry, armed conflict, combatant, operational, armed confrontation. 


\section{INTRODUCCIÓN}

Desde el origen mismo de la humanidad, el hombre siempre ha batallado por satisfacer sus necesidades básicas, la lucha por la tierra, el poder, la libertad, ha marcado los destinos de las sociedades antiguas y modernas, en consecuencia; la guerra constituye una herramienta esencial a partir de la cual se construyen imperios, se logran los objetivos estamentarios, se reactivan las economías, incluso, se logran los mayores alcances tecnológicos.

Partiendo de esa premisa y al entender la confrontación armada como una consecuencia en la evolución del hombre, surge también la necesidad de limitar los efectos que las hostilidades traen en la población civil y sus bienes, para ello y por ello se creó el Derecho Internacional Humanitario (en adelante DIH), como una herramienta normativa y consuetudinaria orientada a limitar los efectos de la lucha armada, reconociendo como un derecho; las razones legítimas que tiene un Estado para hacer la guerra (Ius ad Bellum).

Lo anterior implica que el Estado puede hacer uso de la fuerza de manera legítima en defensa de sus intereses, siempre y cuando respete la dignidad humana (principio de humanidad) y excluya de las consecuencias de los ataques directos a la población civil (principio de distinción), enfocando su esfuerzo bélico solo contra combatientes y objetivos militares, utilizando para tal fin medios y métodos legítimos de hacer la guerra.

Ese es el deber ser del manejo de las hostilidades, que se hace aplicable tanto a los conflictos armados internacionales (en adelante CAI), como a los conflictos armados no internacionales (en adelante CANI), en síntesis, que la confrontación armada se suscite solo entre combatientes.

Se hace énfasis en la palabra combatiente, porque a partir de su identificación surgen consecuencias jurídicas diversas, por un lado, el DIH permite hacer uso de la fuerza legítima en su contra y por el otro, su distinción garantiza no involucrar a la población civil en el desarrollo de las hostilidades, eje central que ha sido objeto de preocupación desde el momento en el cual la dinámica de la guerra empezó a involucrar cada vez más a las personas ajenas al conflicto. En un inicio las guerras se hacían en campos abiertos, ajenos a los cascos urbanos, dos ejércitos se citaban para luchar y solo entre ellos se daban las contiendas. 
La realidad actual es diferente, los bombardeos a las zonas urbanas, los ataques dirigidos a objetivos estratégicos y las armas no convencionales, continúan generando múltiples víctimas entre la población civil, aquello refuerza la necesidad de aplicar las normas del DIH con mayor contundencia especialmente en los CANI, por cuanto su naturaleza asimétrica en ocasiones degrada la lucha armada, en Colombia por ejemplo, el conflicto ha ocasionado múltiples violaciones a los derechos humanos, generando afectación especialmente en las zonas veredales, donde los grupos argados organizados tiene mayor influencia.

Estas organizaciones de facto generalmente de origen campesino, han utilizado entre sus filas a menores de edad, mujeres, milicianos, personas que participan directamente en las hostilidades y combatientes en sentido genérico, para cumplir su objetivos en la búsqueda del poder a través de la insurrección armada, esa multiplicidad de personas con roles tan diversos, hace muy difícil el cumplimiento legítimo del deber Estatal orientado a garantizar la paz y tranquilidad en todo el territorio nacional, ya que el miembro de la fuerza pública que asume la responsabilidad de contrarrestar la amenaza debe tener plena certeza del papel que cumple su contraparte y el marco jurídico en el cual desarrolla su actividad en el teatro de las operaciones.

Dificultad que se hace extensiva al operador judicial que debe analizar, investigar y judicializar si es el caso, el resultado que puede surgir del uso de la fuerza, donde la muerte es una posibilidad y su judicialización depende drásticamente del papel que asume el sujeto pasivo de la conducta en el desarrollo de la confrontación armada, ya que las consecuencias jurídicas pueden ser diversas si se establece que la víctima de la conducta es un combatiente en sentido genérico o una persona que participa directamente en las hostilidades, frente a los cuales puede llegar a operar el fenómeno de la atipicidad de la conducta.

Es precisamente esa dificultad conceptual, la que motiva la presente argumentación, tesis en la que se pretende analizar el papel del combatiente en el conflicto armado colombiano, sus diversas formas de denominación según su grado de participación en las hostilidades y la posibilidad legítima que tiene el Estado para perseguir, neutralizar y reducir sus efectos en el marco del uso de la fuerza, así como la aplicación normativa en cuanto a la responsabilidad de éste. 
Por ello, el presente trabajo se ocupa en primera instancia de analizar el concepto de combatiente, los diversos roles que asume en un CAI y CANI y el alcance jurídico de la participación directa en las hostilidades, todo lo anterior teniendo en cuenta el desarrollo normativo y la jurisprudencia de los diversos órganos colegiados tanto en el contexto interno, como en los Tribunales Internacionales de Justicia, que se han instituido en el seno de la ONU, ya sea de forma permanente o temporal, para investigar y castigar las infracciones al DIH y las violaciones al Derecho Internacional de los Derechos Humanos (en adelante DIDH).

En el mismo sentido, se hará una constatación de los medios y métodos empleados por los Grupos Armados Organizados (en adelante GAO), para cumplir sus objetivos en el desarrollo del conflicto colombiano, con el fin de entender la dificultad que reviste la asimetría de la confrontación armada y la problemática presente a la hora de utilizar la fuerza letal, teniendo la obligación de respetar el principio de distinción en el teatro de las hostilidades.

Finalmente con base en la doctrina operacional, se hará una constatación de los elementos que permiten hacer uno de la fuerza para atacar objetivos legítimos, el tratamiento penal que se debe dar a dicha conducta por parte de los operadores judiciales de la jurisdicción ordinaria y penal militar, teniendo en cuenta para tal fin la directiva 003 de 2015 emanada por la Fiscalía General de la Nación, la reforma constitucional del artículo 221 y la dogmática internacional presente en las decisiones de los Tribunales ad hoc, así como la doctrina especializada del Comité Internacional de la Cruz Roja (en adelante CICR).

Todo lo anterior, con el fin de generar inquietudes en la comunidad académica en general, que permitan concientizar sobre la necesidad de estudiar el aludido marco conceptual, el cual genera consecuencias evidentes en el trasegar jurídico contemporáneo, especialmente por la complejidad que reviste el conflicto colombiano, la mixtura de funciones que asumen tanto los soldados como los policías y el marco jurídico aplicable, en la medida que confluyen dos cuerpos normativos el DIH y el DIDH.

Se busca construir un argumento sobre la base del papel del combatiente y sus diversas denominaciones en el contexto interno, acompañado con la doctrina especializada que surge de instructivos, manuales y directivas relativas al uso de la fuerza, donde el papel del militar y policía es determinante, ya que asume un rol específico en defensa de las instituciones 
legítimas del Estado y por ello, debe tomar decisiones en fracción de segundo, muchas de las cuales involucran la afectación de derechos de terceros, allí su entrenamiento capacitación es indispensable, pero más indispensable aún, es la comprensión de su función por parte de aquel que debe, sentado en un escritorio, analizar el resultado de su acción.

\section{COMBATIENTE, ANÁLISIS DE SU ROL EN LOS DIVERSOS CONFLICTOS ARMADOS}

En la Real Academia de la Lengua Española se define al Combatiente como: "cada uno de los soldados que combaten en un ejército" (RAE, 2016), definición que permite señalar que dicha denominación aplica desde la perspectiva dogmática solamente para los conflictos armados de carácter internacional (en adelante CAI), en ese contexto, solo los combatientes tiene derecho a atacar a su adversario, así lo contempla el reglamento de la Haya aprobado el 18 de octubre de 1907 en su artículo primero al señalar:

Calidad de Beligerante

Art. 1. Las leyes, los derechos y los deberes de la guerra no se refieren solamente al ejército sino también a las milicias y a los Cuerpos de voluntarios que reúnan las condiciones siguientes:

1. Tener a la cabeza una persona responsable por sus subalternos;

2. Tener una señal como distintivo fijo y reconocible a distancia;

3. Llevar las armas ostensiblemente;

4. Sujetarse en sus operaciones a las leyes y costumbres de la guerra.

En los países en que las milicias o los Cuerpos de voluntarios formen el ejército o hagan parte de él, tanto aquéllas como éstos quedan comprendidos bajo la denominación de ejército. (CICR, 1907)

Norma concordante con el Protocolo I adicional a los Convenios de Ginebra de 1949 relativo a la protección de las víctimas de los conflictos armados internacionales aprobado el 8 de junio de 1977, en cuál es su artículo 43 dispone:

1. Las fuerzas armadas de una Parte en conflicto se componen de todas las fuerzas, grupos y unidades armados y organizados, colocados bajo un mando responsable de la conducta de sus subordinados ante esa Parte, aun cuando ésta esté representada por un gobierno o por una autoridad no reconocidos por una Parte adversa. Tales fuerzas armadas deberán estar sometidas a un régimen de disciplina interna que haga cumplir, inter alia, las normas de derecho internacional aplicables en los conflictos armados.

2. Los miembros de las fuerzas armadas de una Parte en conflicto (salvo aquellos que formen parte del personal sanitario y religioso a que se refiere el artículo 33 del III Convenio) son combatientes, es decir, tienen derecho a participar directamente en las hostilidades. 
3. Siempre que una Parte en conflicto incorpore a sus fuerzas armadas un organismo paramilitar o un servicio armado encargado de velar por el orden público, deberá notificarlo a las otras Partes en conflicto. (CICR, 1977)

Marco normativo que recoge y unifica disposiciones jurídicas que nacieron de la costumbre internacional (CICR, 2010) por ello, están integradas a la legislación interna por cuanto hacen parte del bloque de constitucionalidad y su aplicación como lo señala la Corte Constitucional (en adelante la Corte), constituye una fuente de interpretación obligatoria de respecto y aplicación por las partes en conflicto, en palabras de la Corte:

En Colombia no sólo el derecho internacional humanitario es válido en todo tiempo sino que, además, opera una incorporación automática del mismo "al ordenamiento interno nacional, lo cual, por lo demás, es lo congruente con el carácter imperativo que, según ya fue explicado, caracteriza a los principios axiológicos que hacen que este cuerpo normativo integre el ius cogens. (Sentencia C225, 1995)

Respecto del Bloque de Constitucionalidad en la misma decisión dispuso que:

El bloque de constitucionalidad está compuesto por aquellas normas y principios que, sin aparecer formalmente en el articulado del texto constitucional, son utilizados como parámetros del control de constitucionalidad de las leyes, por cuanto han sido normativamente integrados a la Constitución, por diversas vías y por mandato de la propia Constitución. Son pues verdaderos principios y reglas de valor constitucional, esto es, son normas situadas en el nivel constitucional, a pesar de que puedan a veces contener mecanismos de reformas diversas al de las normas del articulado constitucional stricto sensu. (Sentencia C225, 1995)

Todo lo anterior para señalar que las normas y costumbres de la guerra deben ser aplicadas en cualquier clase de conflicto armado (internacional o no), que las partes en contienda deber respectar dicho cuerpo normativo, el cual le otorga según su naturaleza una especial condición y ámbito de protección, permitiendo que las hostilidades solamente se dirijan hacia objetivos militares, manteniendo alejados de las consecuencias de la guerra a la población civil, núcleo duro presente en el DIH.

Partiendo de esa premisa, debemos decir que las partes en conflicto asumen una denominación teniendo en cuenta el rol y la intensidad de la confrontación armada, en los CAI, la denominación de combatiente permite por ejemplo, dar cuartel a los prisiones de guerra, los cuales no pueden ser castigados por haber hecho parte de la fuerza armada opositora, (Artículo 44 Protocolo I) y son objeto de protección especial por el DIH. 
En un CANI, la denominación varía, por cuanto desde la perspectiva del derecho internacional ya no es considerado como combatiente sino como un miembro de un grupo armado, esta especial condición no lo priva de la protección prevista para los combatientes en un CAI, pero si lo diferencia en cuanto a su trato en caso tal de que caiga en manos de su adversario, ya que si se trata de una organización de iure ${ }^{1}$ que combate una de facto $^{2}$, los miembros de estos grupos no tienen estatus de prisioneros de guerra, sino deberá aplicársele la legislación interna y las normas previstas en el ordenamiento punitivo (rebelión, sedición ${ }^{3}$ ) (Segura, 2007).

Esta diferenciación resulta determinante en el contexto de las hostilidades, en la medida que dicho tratamiento trae consecuencias jurídicas diversas para uno y otro grupo armado, por ejemplo, en caso de una muerte que surja como consecuencia del uso legítimo de la fuerza, se podría configurar el fenómeno de la atipicidad, no así al revés, es decir si un guerrillero da muerte a un soldado estamos frente a un homicidio, que debe ser castigado de conformidad con la normatividad interna, estos aspectos serán desarrollados más adelante.

Al igual se resalta la diferencia en cuanto a la pérdida de la protección cuando se trata de un miembro de la población civil que participa directamente en las hostilidades, en el contexto de la normativa internacional, por esa actividad pierde la protección frente a los ataques directos (Sentencia Casación 14225, 2010), lo cual debe ser analizado consumo cuidado en el proceso militar de la toma de decisiones, si se quiere por ejemplo, hacer uno de la fuerza legítima, ya que ante la duda subsiguiente deberá ser considerado como población civil. Aquello da un margen limitado de movimiento para el miembro de la fuerza armada si se tiene en cuenta la particularidad del conflicto colombiano, donde en muchos casos se utilizan miembros de la población civil para ejecutar actos a veces más crueles (activación de campos minados), que los que podría realizar un guerrillero uniformado y con un Ak47 en actitud hostil (Guévara, 2004).

\footnotetext{
${ }^{1}$ Se refiere a los Miembros de las Fuerzas Militares Legítimas de un Estado en un conflicto armado no internacional.

${ }^{2}$ Se refiere a los Grupos Armado Ilegales (Guerrilla- Autodefensas) que luchan con el Estado.

${ }^{3}$ Ley 599 de 2000, Código Penal Art. 467 y 468
} 
Estas particularidades que el conflicto asimétrico trae inmerso, además de las diferentes denominaciones según el rol que asumen y el conflicto armado en el cual se desarrollen las hostilidades, serán objeto de estudio en los apartados siguientes, haciendo especial énfasis en el caso colombiano, país que desde la década de los 50, ha sufrido las consecuencias de un conflicto armado degradado, brutal, que ha dejado miles de víctimas de todos los estratos y condiciones sociales. Entender las particularidades de la guerra en una confrontación armada de esa naturaleza es un imperante académico que justifica cualquier esfuerzo argumentativo.

En consecuencia, a continuación se hará un análisis de los diferentes roles que asumen los integrantes de los bandos en contienda, tanto en CAI como en CANI, el marco jurídico aplicable, las consecuencias previstas por la normatividad en relación con el uso de la fuerza, la aplicación de los principios del DIH y la posibilidad de ataque para las personas que participan directamente en las hostilidades, todo ello de cara a la doctrina especializada, jurisprudencia y los tratados internacionales que como ya se destacó, hacen parte de la costumbre internacional y con ello del bloque de constitucionalidad en un conflicto como el que ha vivido Colombia, el cual desde sus orígenes, siempre ha involucrado a la población civil y por ello el surgimiento de las víctimas es una constante especialmente en el área rural.

\subsection{El combatiente en los Conflictos Armados Internacionales (CAI)}

En un Conflicto Armado Internacional, todos los miembros de las fuerzas armadas tienen el estatus de combatiente, esta especial condición les otorga unos privilegios que surgen de la normativa internacional (Protocolo I), entendiéndose como fuerza armada toda organización cuyos miembros:

- Estén bajo un mando responsable ante la parte en conflicto por el comportamiento de sus subordinados (aunque dicha parte esté representada por un gobierno o una autoridad que la otra parte en conflicto no haya reconocido)

- Estén sometidos a un régimen de disciplina interna que haga cumplir la observancia del derecho de los conflictos armados; y

- Lleven, al menos cuando estén desplegados en operaciones militares, uniformes o se distingan de la población civil de otra manera. (Mejia, 2010, pág. 208)

Esta clase de personas, que hacen parte de la estructura cuyos elementos se citaron, tienen derecho a participar directamente en las hostilidades, al igual que atacar objetivos militares y deben ser tratados como prisioneros de guerra en caso de caer en manos de su adversario 
(Protocolo I, Art 44). Privilegio que surgen de la legitimidad aludida a la guerra internacional, según la cual; los Estados tienen derecho a hacer la Guerra, Ius ad Bellum, acudir a la confrontación armada en defensa de sus intereses, de su territorio, de su identidad cultural y libertad.

Bajo ese criterio según el CICR, “(...) en virtud de la Carta de las Naciones Unidas, los Estados se abstendrán de recurrir a la amenaza o al uso de la fuerza contra la integridad territorial o la independencia política de cualquier Estado (art. 2(4)). Se podrá exceptuar este principio en los casos de defensa propia y tras una decisión adoptada por el Consejo de Seguridad de las Naciones Unidas en virtud del Capítulo VII de la Carta de las Naciones Unidas" (CICR, 2010).

Lo anterior ubica a los miembros de las fuerzas armadas en la condición especial de hacer o realizar ataques y ser susceptibles de estos, en los CAI, por su naturaleza, intensidad y particularidad, se excluyen de esta condición al personal sanitario y religioso, que si bien es cierto hacen parte de las organización militar, están protegidos frente a sus ataques directos, por cuanto su función y naturaleza no está orientada a la lucha armada, sino a funciones equiparables a la condición de población civil, por ello utilizan símbolos protectores.

Al respecto es importante mencionar que dichos símbolos o emblemas distintivos, garantizan la protección frente a ataques directos, especialmente para el personal sanitario o neutral que cumple una función eminentemente humanitaria en el campo de combate, en ese sentido el Departamento Federal de Asuntos Exteriores de Suiza señaló:

En los conflictos armados, los emblemas reconocibles sirven sobre todo para proteger de los ataques (función de protección) las instalaciones sanitarias militares y civiles, y los edificios y el personal de las organizaciones nacionales de socorro. Esta protección no está garantizada por los propios emblemas pero se basa directamente en el Derecho Internacional. En tiempos de paz, a las sociedades nacionales de la Cruz Roja, la Media Luna Roja y el Cristal Rojo se les permite utilizar estos emblemas para las actividades que sean compatibles con sus principios fundacionales (función indicativa). Las Convenciones de Ginebra de 1949 reconocen como emblemas la Cruz Roja, la Media Luna Roja y el León Rojo y el Sol Rojo (abandonado en 1980). El Cristal Rojo fue reconocido como emblema adicional en 2005 para ser utilizado por todos los Estados que por razones religiosas o de otro tipo no deseen hacer uso de los otros emblemas. (DFAE, 2014, pág. 29) 
Lo cual nos permite señalar, que si bien es cierto en los CAI, existen personas que hacen parte de las fuerzas armadas, por ese solo hecho no adquieren la condición de combatientes, incluso pueden llevar armas ligeras para su defensa o del personal que está bajo su protección, y no por ello se pueden catalogar como objetivos militares (I Convenio de Ginebra Art 13).

\subsubsection{Derechos del Combatiente}

Su principal derecho es a participar en las hostilidades, en ese contexto, puede hacer uso de la fuerza legítima en defensa de su integridad y de la institución que representa, según ello, le es permitido atacar objetivos militares y también ser susceptible de ataque, además tiene derecho a ser tratado como prisionero de guerra en caso de ser capturado por el enemigo, goza de la protección que contiene los principios de Derecho Internacional Humanitario como el de humanidad, limitación, y todas aquellas normas que salvaguardan a los náufragos, heridos, y enfermos, al respecto el CICR ha señalado:

El núcleo fundamental de los derechos del combatiente radica en la idea de que tiene derecho a participar en las hostilidades y no puede ser castigado a causa de los resultados lesivos que ocasione, en las personas o en las cosas. A su vez, está protegido por el Derecho de los Conflictos Armados, de tal manera que, mientras combate, se beneficia del principio de limitación de medios y métodos que prohíbe causarle males superfluos y sufrimientos innecesarios, y, si cae en poder de la Parte adversa, tiene derecho a ser tratado como prisionero de guerra. Además, en su caso, puede obtener una protección especial concedida a los heridos, enfermos o náufragos (Doménech, 2003).

Partiendo de la anterior premisa, el DIH divide los combatientes, es decir, aquellos que hacen parte de la confrontación armada de los no combatientes, aquellos que no hacen parte de la confrontación armada o han dejado de hacerlo, dando a cada categoría una protección especial, lo que constituye un derecho respecto del uso de la fuerza letal, así por ejemplo, en relación con el principio de limitación, el combatiente tiene derecho a no sufrir daños o sufrimientos innecesarios.

Según Henckaerts, la limitación implica la "prohibición o restricción de ciertos métodos y armas de combate cuando se trata de métodos y de armas que causan daños superfluos, innecesarios o excesivos o que por su insuficiente precisión no permiten hacer la distinción fundamental entre objetivos militares o protegidos o cuyos efectos pueden extenderse, de manera incontrolable en el tiempo y en el espacio" ( Henckaerts, 2005). 
En cuanto a los métodos, como lo señala Kelly Chaib De Mare:

(...) se involucran todas aquellas estrategias o procedimientos tales como la perfidia, la orden de no dejar supervivientes o de tierra arrasada, el terrorismo, el envenenamiento de aguas, o el hambre cuando se imparten ordenes de cortar las líneas de abastecimiento a la población civil y de atacar los bienes indispensables para la supervivencia de la misma. Para el caso del empleo de armas, se encuentra proscrito el uso aquellas que causan daños innecesarios e indiscriminados, extensos, duraderos y graves contra la persona humana, independientemente de su condición como combatiente, no combatiente o civil, y contra el medio ambiente. Entre otras, se pueden citar armas químicas, bacteriológicas, nucleares e incendiarias, minas antipersona, cuya fabricación, importación, posesión y uso están prohibidos (De Mare, 2016, pág. 4).

Según Henckaerts (2005). Lo que se traduce en un derecho para el combatiente, que si bien es cierto es susceptible de ataque, no por ello puede ser sometido a vejaciones o tratos que vayan en contravía con la dignidad humana, la cual nunca puede dejar de ser observada por cuanto constituye la piedra angular del principio de humanidad ${ }^{4}$, presente tanto en el DIH como en el DIDH, así quedó reconocido por la Corte Interamericana de Derechos Humanos al señalar:

El trato humano, en toda y cualquier circunstancia, abarca todas las formas de comportamiento humano y la totalidad de la condición de la vulnerable existencia humana. Más que una disposición de aquellas garantías, el trato humano corresponde al principio de humanidad, que traspasa todo el corpus juris del Derecho Internacional Humanitario, convencional así como consuetudinario. Esta consideración me conduce a mi segunda precisión: es necesario tomar en cuenta, a un tiempo, a la par del derecho internacional convencional, también el derecho internacional general (CIDH, 2004).

En virtud de lo dicho anteriormente, el combatiente tiene derecho a ser tratado con dignidad, cuenta con estatus de prisionero de guerra y puede atacar objetivos militares en el desarrollo de una confrontación armada, su participación no se limita en el tiempo en el cual se esté presentando la hostilidad, se extiende más allá, por lo que incluso sin estar directamente en tareas de combate, por ejemplo en desplazamientos, en descanso, en labores administrativas, en los cuarteles, puede ser atacado (Gutiérrez, 2014).

\footnotetext{
4 “El principio de humanidad ordena dar prioridad al respeto de la persona sobre las necesidades militares. Su propósito es confirmar la inmunidad fundamental de las personas civiles contra ataques en todo conflicto armado. Según este principio, está prohibido infligir sufrimiento, lesión o destrucción que no sean verdaderos y estrictamente necesarios para obtener propósitos militares legítimos. En consecuencia, las acciones militares sólo deben causar el efecto necesario para el cumplimiento de la misión y no el mayor porque sería inhumano y poco eficaz". ( Henckaerts, 2005)
} 
No sucede lo mismo con los miembros de la fuerzas armadas que hacen parte del personal sanitario o religioso, el cual incluso al estar uniformado y armado, no pierde la protección frente a ataques directos, además es considerado por la legislación colombiana como una persona protegida (Artículo135 No 4 ley 599, 2000).

Esa denominación está vigente en el Protocolo I como ya se señaló, instrumento que define en el artículo 8, lo que se debe entender por personal sanitario y religioso:

c) se entiende por personal sanitario las personas destinadas por una Parte en conflicto exclusivamente a los fines sanitarios enumerados en el apartado e), o a la administración de las unidades sanitarias o al funcionamiento o administración de los medios de transporte sanitarios. El destino a tales servicios podrá tener carácter permanente o temporal. La expresión comprende:

i) el personal sanitario, sea militar o civil, de una Parte en conflicto, incluido el mencionado en los Convenios I y II , así como el de los organismos de protección civil;

ii) el personal sanitario de las Sociedades nacionales de la Cruz Roja (Media Luna Roja, León y Sol Rojos) y otras sociedades nacionales voluntarias de socorro debidamente reconocidas y autorizadas por una Parte en conflicto;

iii) el personal sanitario de las unidades o los medios de transporte sanitarios mencionados en el párrafo 2 del artículo 9 ;

d) se entiende por personal religioso las personas, sean militares o civiles, tales como los capellanes, dedicadas exclusivamente al ejercicio de su ministerio y adscritas:

i) a las fuerzas armadas de una Parte en conflicto,

ii) a las unidades sanitarias o los medios de transporte sanitarios de una Parte en conflicto,

iii) a las unidades o medios de transporte sanitarios mencionados en el párrafo 2 del artículo 9 , o

iv) a los organismos de protección civil de una Parte en conflicto.

La adscripción del personal religioso puede tener carácter permanente o temporal.. (CICR, 1977)

El objeto de su protección está relacionado con la función que cumplen en el campo de batalla la cual es estrictamente humanitaria, la naturaleza de su servicio en el combate está alejado del uso de la fuerza y muchos de ellos optan por no portar armas acudiendo al principio de objeción de conciencia (Beltran, 2005), los que deciden portarlas deben tener claro que estas solamente pueden ser utilizadas como medio defensivo suyo o de un tercero bajo su cuidado o asistencia, caso contrario pierden la protección frete a ataques directos pro cuanto se conviertes en participe directo de las hostilidades (Contreras, 1989, pág. 163).

\subsubsection{Obligaciones de los combatientes}

No solo derechos tiene el combatiente, también tiene obligaciones que surgen del marco normativo previsto en el DIH, tal vez la más importante de ellas, es que en el desarrollo de las 
hostilidades y en cumplimiento de su función respete las leyes de la guerra, proporcione trato digno a los prisioneros de guerra, que utilice medios y métodos que causen el menor daño posible a sus adversarios y mantengan alejadas de las consecuencias de la guerra a la población civil, al respecto Henckaerts señala:

La principal obligación del combatiente reside en ajustar su conducta al Derecho de los Conflictos Armados, respecto a los combatientes enemigos, absteniéndose de utilizar medios y métodos de combate prohibidos y dando el trato debido a los heridos, enfermos y náufragos y a los prisioneros de guerra. Con respecto a la población civil y a los bienes civiles tiene el deber de respetarlos y protegerlos ( Henckaerts, 2005).

Además de lo anterior, tiene la obligación de distinguirse de la población civil mientras adelante sus actividades, evitando involucrarla en el desarrollo de la confrontación armada, esa verificación debe estar presente desde el mismo momento en el cual se planea la operación. Al respecto, es importante señalar que las operaciones tienen dos fases; una de planeación y otra de ejecución, en las dos se deben tener en cuenta como mínimo lo siguientes criterios de la costumbre internacional, que fueran recogidos por la Corte en la sentencia C291 de 2007 a saber:

- El deber de las partes de en conflicto de verificar, por todos los medios disponible, que los objetivos que se van a atacar son militares.

- El deber de las partes en conflicto de elegir los medios y métodos bélicos que eviten o minimicen el número de muertos, heridos y daños materiales causados accidentalmente a la población civil.

- El deber de las partes en conflicto de tomar todas las acciones posibles, de conformidad con las circunstancias, para dar aviso a la población civil de cualquier ataque que pueda afectarla, si ello es necesario antes, durante o después de una confrontación armada.

- El deber de las partes en conflicto de elegir, cuando existan varios objetivos militares con una ventaja similar, el objetivo militar que represente menor peligro para las personas y bienes civiles.

- El deber de las partes en conflicto de retirar a la población civil de la vecindad de los objetivos militares, al mayor grado posible. 
- El deber de la partes de no ubicar objetivos militares en zonas densamente pobladas o cerca de estas.

De lo anterior se desprende que el combatiente tiene la obligación además de distinguirse de la población civil, de utilizar los medios y métodos menos lesivos de cara a la ventaja militar $^{5}$ concreta perseguida, debe evitar daños superfluos, innecesarios e indirectos si con ello no contribuye de manera eficaz al debilitamiento de su adversario, lo cual hace pensar entonces, que si bien es cierto el DIH presupone la posibilidad de causar afectaciones a la población, esos daños deben ser ponderados por el combatiente teniendo en cuenta la necesidad militar $^{6}$, debe tener plena certeza al hacer uso de la fuerza y medir con mucho cuidado las consecuencias esperadas con la actuación en el teatro de los acontecimientos (Valencia, 1991).

Por lo cual se puede asegurar que el combatiente tiene la obligación principal de aplicar el DIH y proporcionar el mismo trato al que tiene derecho por su especial condición de miembro regular de un Estado legítimo (Villarraga, 1998), cualquier actuación debe por ende; enaltecer ese papel que asume en defensa de los interés de la nación que representa, todo hecho ilegal que contradiga las costumbres de la guerra, lo hará perder el estatus aludido y con ello merecedor de castigo de conformidad con la normativa de la parte en contienda o en su defecto del Estatuto de Roma a través de la CPI.

\subsection{El combatiente en los conflictos armados no internacionales CANI}

Es importante señalar que en materia de CANI, a las personas que participan en las hostilidades no se les denomina combatientes, la denominación que se desprende del Artículo

\footnotetext{
5 “La expresión se utiliza en el derecho de los conflictos armados cuando se da la definición de objetivo militar, y cuando se estipulan las precauciones que deben tomarse en el ataque a fin de preservar tanto como sea posible a la población civil, a las personas civiles y los bienes de carácter civil (cf. GP I, arts. 51, 52, 57)". Tomado de manera literal de: https://www.fac.mil.co/francesgaama/ventaja-militar. Formato web. Fecha de consulta 12/06/2016.

6 "El principio de necesidad militar es uno de los principios generales de la conducción de las hostilidades. La fuerza militar debe ser necesaria y proporcionada (Proporcionalidad), y distinguir entre civiles y combatientes, así como entre bienes civiles y objetivos militares. La preocupación fundamental del Derecho Internacional Humanitario es asegurar que se logre un equilibrio entre la necesidad militar y las consideraciones humanitarias". (DFAE, 2014)
} 
43 numeral 2 del Protocolo Adicional I a los Cuatro Convenios de Ginebra es integrante de un grupo armado, aquella alusión también es recogida por la Doctrina del CICR al señalar:

Los grupos armados organizados que pertenecen a una parte no estatal en un conflicto armado incluyen tanto a las fuerzas armadas disidentes como a otros grupos armados organizados. Las fuerzas armadas disidentes constituyen, esencialmente, una parte de las fuerzas armadas de un Estado que se ha vuelto en contra del gobierno. Otros grupos arados organizados reclutan a sus miembros sobre todo entre la población civil, pero el grado de organización militar que alcanzan es suficiente para conducir las hostilidades en donde de una parte en conflicto aunque no siempre con los mismos medios, o intensidad y nivel tecnológico que las fuerzas armadas estatales (Melzer, 2010, pág. 31).

No obstante lo anterior, la Corte ha construido un término que permite la denominación de combatiente en un sentido diferente al otorgado por la doctrina del CICR antes citada, en dicha decisión se contempla la existencia de dos clases de combatientes, uno de sentido especifico aludido a CAI y otro en sentido genérico para los que intervienen en un CANI, en esencia señaló:

El término "combatientes" en Derecho Internacional Humanitario tiene un sentido genérico, y un sentido específico. En su sentido genérico, el término "combatientes" hace referencia a las personas que, por formar parte de las fuerzas armadas y los grupos armados irregulares, o tomar parte en las hostilidades, no gozan de las protecciones contra los ataques asignadas a los civiles. En su sentido específico, el término "combatientes" se utiliza únicamente en el ámbito de los conflictos armados internacionales para hacer referencia a un status especial, el "status de combatiente", que implica no solamente el derecho a tomar parte en las hostilidades y la posibilidad de ser considerado como un objetivo militar legítimo, sino también la facultad de enfrentar a otros combatientes o individuos que participan en las hostilidades, y el derecho a recibir trato especial cuando ha sido puesto fuera de combate por rendición, captura o lesión - en particular el status conexo o secundario de "prisionero de guerra". Precisa la Corte que para los efectos del principio de distinción en su aplicación a los conflictos armados internos, y de las distintas reglas que lo componen en particular, el Derecho Internacional Humanitario utiliza el término "combatientes" en su sentido genérico. Está fuera de duda que el término "combatientes" en sentido específico, y las categorías jurídicas adjuntas como "status de prisionero de guerra", no son aplicables a los conflictos armados internos (Sentencia C291, 2007).

A la luz de la jurisprudencia antes citada, las personas que participan en un CANI, se denominan combatientes en sentido genérico, por ello pierden la protección frente a ataques directos por cuanto asumen una función continua de combate, dicha denominación permite hacer uso de la fuerza legítima en el marco del DIH como primera opción, es una posición 
asimilable al combatiente en sentido especifico que se analizó en precedencia, sin querer afirmar con ello que se le otorga el estatus del que goza esta persona en el CAI.

La Fiscalía General de la Nación, al querer dotar a sus funcionarios de herramientas necesarias a la hora de judicializar un delito que reúna las condiciones objetivas para ser catalogado en el marco del conflicto armado, en la Directiva 03 de 2015, esquematizó el sentir de la Corte de la siguiente manera:

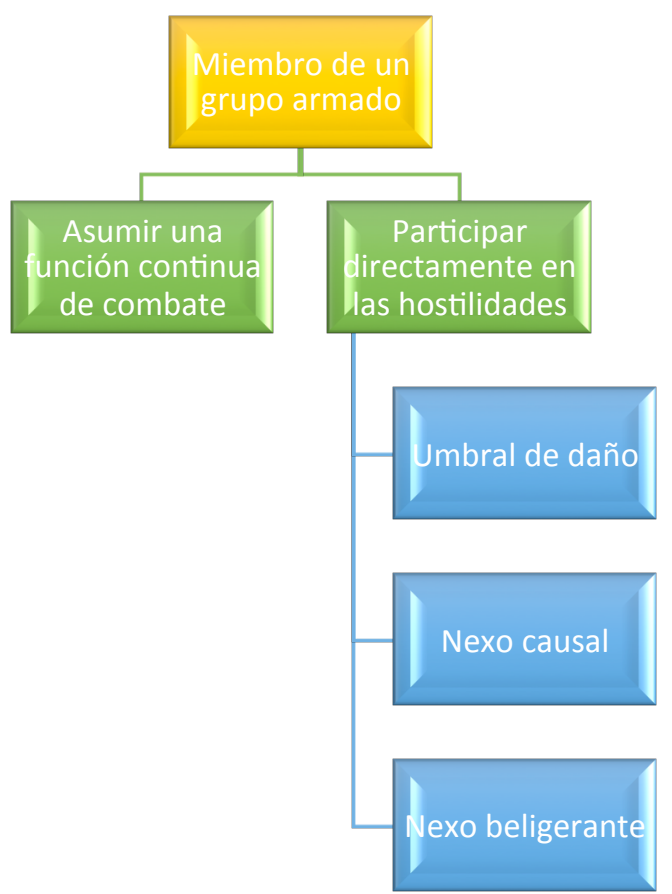

Gráfica 1. Herramientas necesarias a la hora de judicializar un delito. (Fiscalia, 2015)

De dicha esquematización, se desprende una conclusión que vale la pena resaltar; reconoce la existencia de dos personas que podrían ser consideradas como miembros del grupo armado, aquellos que asumen una función continua de combate, por ejemplo los miembros de los frentes de las FARC, del ELN o de las Brandas criminales ${ }^{7}$ (GAO), que según el Ministerio de Defensa han superado el umbral de violencia necesario para utilizar la fuerza como primera opción (Ministerio de Defensa, 2016).

\footnotetext{
${ }^{7}$ Según se destaca de la Directiva Ministerial 015 de 2016, tres Bandas criminales son considerados (GAO), se refiere a los Puntilleros con influencia en los llanos Orientales, los Pelusos, disidencias del EPL que delinquen principalmente en el Catatumbo y el Clan del Golfo cuya área de influencia primaria es el eje Antioquia, Urabá y Choco.
} 
Estos grupos de manera permanente están cumpliendo los objetivos de la estructura ilegal y las personas que participan directamente en las hostilidades, en donde podrían estar los milicianos, auxiliadores, reclutadores, simpatizantes, informantes, proveedores de armas y municiones, entre otros (Giraldo, 2009).

Esa posición también es reconocida por la Corte Suprema de justicia, que denomina a las partes en un CANI, como el que padece Colombia desde hace más de 50 años combatientes, en esencia señaló:

A la luz del derecho internacional humanitario, el término combate hace relación a un choque armado entre combatientes, es decir, se le da tal categoría a los enfrentamientos suscitados entre miembros de las fuerzas armadas constitucionales y los guerrilleros o grupos disidentes. De esta manera, toda acción en la que se utilicen las armas como medio de enfrentamiento, es admitida como posible, pues los combatientes tienen la categoría de blanco legítimo (Sentencia Corte Suprema, 1999).

También se precisó que en estas circunstancias, es de entenderse que la población civil no hace parte de las fuerzas sediciosas ni gubernamentales y que no forma parte de ese combate, razón por la cual no puede ser tenida como blanco legítimo, ni las acciones dirigidas en su contra catalogada como propias de un combate.

Ahora bien, al margen de la denominación de la Corte o de los instrumentos internacionales en torno a los miembros de los grupos armados organizados (GAO), el legislador también le otorgó una calificación especial, por ejemplo la Ley 975 de 2005 (ley de justicia y paz), los describe e identifica de la siguiente manera:

Artículo $1^{\circ}$. Objeto de la presente ley. La presente ley tiene por objeto facilitar los procesos de paz y la reincorporación individual o colectiva a la vida civil de miembros de grupos armados al margen de la ley, garantizando los derechos de las víctimas a la verdad, la justicia y la reparación.

Se entiende por grupo armado organizado al margen de la ley, el grupo de guerrilla o de autodefensas, o una parte significativa e integral de los mismos como bloques, frentes u otras modalidades de esas mismas organizaciones, de las que trate la Ley 782 de 2002 (Senado, 2005). (Subrayado fuera de texto)

Es decir, le da la categoría de miembro de grupo armado organizado, denominación también presente en el acto legislativo No 1 de 2012 (marco jurídico para la Paz), en donde se dispone por el legislador: 
En ningún caso se podrán aplicar instrumentos de justicia transicional a grupos armados al margen de la ley que no hayan sido parte en el conflicto armado interno, ni a cualquier miembro de un grupo armado que una vez desmovilizado siga delinquiendo (Alcadia de Bogota, 2012).

De lo antes expuesto como lo destacara la Fiscalía en la Directiva 003 de 2015, se pueden distinguir tres clases de participación en las hostilidades en los CANI, "(i). Los civiles que participan directamente en las hostilidades; (ii) los miembros de un grupo armado (combatiente en sentido genérico) (iii) los civiles que participan indirectamente en las hostilidades" (Fiscalia, 2015), de estos solamente los combatientes en sentido genérico pueden ser objeto de ataque continuo por parte de la fuerza pública, los demás pierden su protección frente a ataques directos en la medida que participan en las hostilidades (Protocolo I Art. 53).

Partiendo de dicha clasificación, el combatiente en sentido genérico es equiparable al miembro del grupo armado al margen de la ley (solo en cuanto hace alusión a miembros de las FARC, ELN o GAO), esta persona cumple una función continua de combate y por ello es susceptible de ataque directo, es decir, el Estado puede hacer uso de la fuerza como primera opción, siempre y cuando cumpla con los principios del DIH, en relación con las otras dos clasificaciones, como se verá a continuación, no dejan de ser parte de la población civil, por ello, solo pueden ser atacados mientras desarrollen las actividades que superen el umbral de daño suficiente para perder la protección asignada por regla general (Galisoga, 2013, pág. 176).

\subsubsection{Los civiles que participan directamente en las hostilidades}

Como fuera destacado por la Comisión Interamericana de Derecho Humanos en el tercer Informe sobre la situación de los derechos humanos presentado al Estado colombiano, una persona civil participa directa o directamente en las hostilidades cuando, individualmente o como miembro de un grupo, asume el papel de combatiente. Dichas personas civiles constituyen una amenaza inmediata de daño cuando se preparan, participan y retornan del combate. Como tales, quedan expuestas a ataques directos. Más aun debido a sus actos hostiles, esas personas civiles pierden los beneficios de los que gozan los civiles pacíficos (Comisión Interamericana, 1999). 
Lo señalado por la Comisión Interamericana, resalta una dificultad que debe analizar de manera permanente el miembro de la fuerza pública cuando se encuentra en el teatro de operaciones, debe establecer si puede hacer uso de la fuerza legítima en contra de quien participa directamente en las hostilidades, con la preocupación de que el resultado de su actuación va a ser analizado por el operador judicial al momento de investigar el hecho.

Para diseminar dicha intranquilidad, el CICR, organización autorizada para generar doctrina en materia del Derecho Internacional Humanitario a través de Nils Melzer creo la "Guía para interpretar la noción de participación directa en las hostilidades según el derecho internacional humanitario"s.

Dicho documento señala tres requisitos acumulativos para establecer cuando se participa directamente en las hostilidades y por ende se pierde el ámbito de protección como integrante de la población civil, especialmente al unirse al esfuerzo bélico en contra de la fuerza pública, tales requisitos son: el umbral de daño, la causalidad directa y el nexo beligerante.

Esa participación directa en las hostilidades se constituye en una excepción de protección contenida en el primer numeral del Artículo 3 común a los Cuatro Convenios de Ginebra y los literales que lo desarrollan, ya que es a partir de allí, donde se introduce en el DIH el ámbito de protección para todas aquellas personas que no hagan parte activa en el desarrollo de la confrontación armada, por ende, aquellas que lo hagan a la luz de la doctrina internacional, podrán ser catalogadas como participantes activos de la hostilidad, siempre y cuando sus actos cumplan los siguientes requisitos acumulativos:

1. Debe haber probabilidades de que el acto tenga efectos adversos sobre las operaciones militares o sobre la capacidad militar de una parte en un conflicto, o bien, de que cause la muerte, heridas o destrucción a las personas o los bienes protegidos contra los ataques directos. (Melzer, 2010, pág. 48)

2. Debe haber un vínculo causal directo entre el acto y el daño que pueda resultar de ese acto o de la operación militar coordinada de la que el acto constituye parte integrante. (Melzer, 2010, pág. 48)

\footnotetext{
${ }^{8}$ Disponible en: http://www.icrc.org/spa/resources/documents/publication/p0990.htm.
} 
3. El propósito específico del acto debe causar directamente el umbral exigido de daño en apoyo de una parte en conflicto y en menoscabo de otra. (Melzer, 2010, pág. 48)

Partiendo de dicha construcción normativa, el CICR a través de su interlocutor (Melzer, 2010), considera que una persona participa directamente en las hostilidades y por ello pierde su protección directa, cuando cumpla con tres requisitos acumulativos, los cuales se pueden diagramar de la siguiente manera:

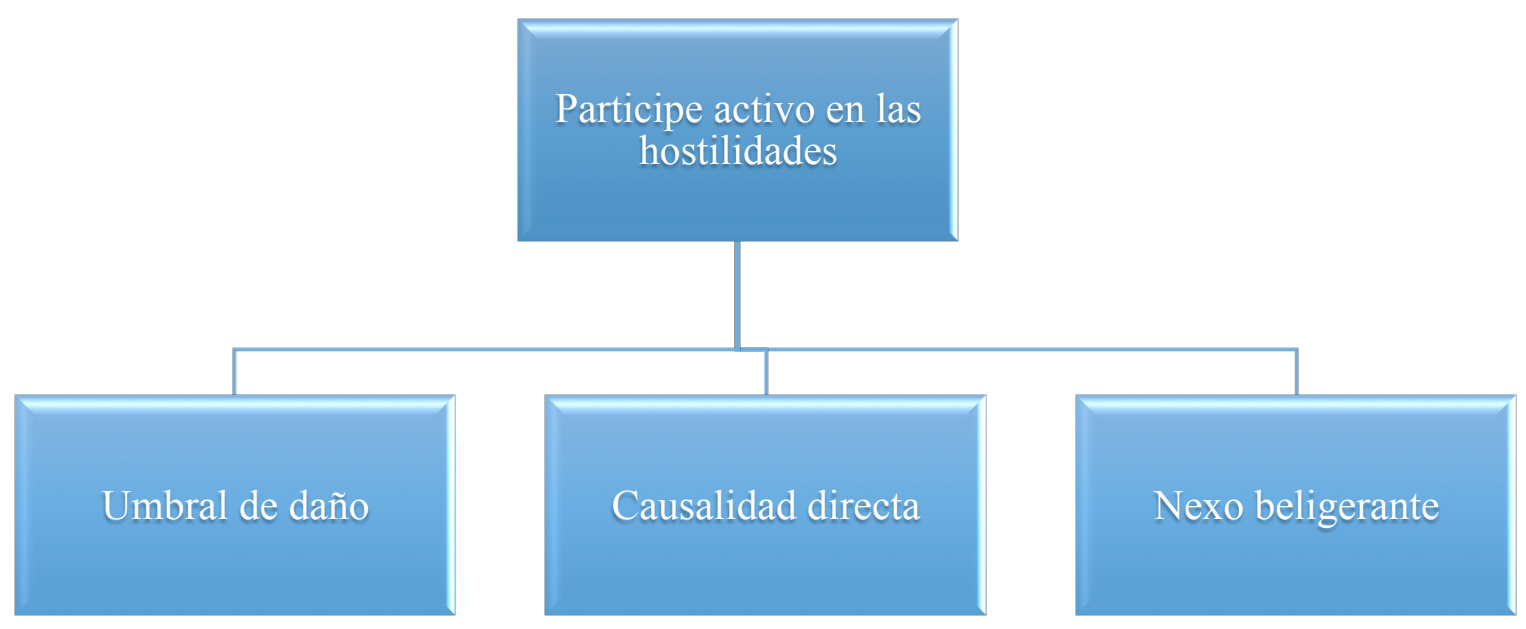

Gráfica 2. Tres requisitos acumulatorios. (Marín, 2016)

Partiendo de dicha clasificación, "para que un acto especifico alcance el umbral de daño exigido, debe haber probabilidades de que el acto tenga efectos adversos sobre las operaciones militares o sobre la capacidad militar de una parte en un conflicto, o bien, de que cause la muerte, heridas o destrucción a las personas o los bienes protegidos contra los ataques directos". (Melzer, 2010, pág. 78)

Las labores de inteligencia por ejemplo, desarrollados por personas vestidas de civil que aprovechando la confianza que los miembros de una base militar le depositan ya que de manera cotidiana le suministran algunos productos esenciales de la canasta familiar, que develen al grupo armado la composición, dispositivo y fuerza, podrían alcanzar el umbral de daño requerido en torno a su participación, si de ello deviene como mínimo la probabilidad de 
que una estructura al margen de la ley desarrolle un ataque valiéndose de dicha información privilegiada.

No es necesario entonces que se materialicen los actos y que con ello se afecten la vida o bienes de la fuerza militar o de la población civil circundante, basta que se presente la probabilidad de la acción para alcanzar el requisito pretendido por el CICR, así lo destaca la fiscalía cuando al analizar este aspecto en la varias veces citada Directiva 003 señala:

Cumplir con el umbral del daño requerido: Este se puede alcanzar causando daños de tipo militar o con ataques a bienes y personas protegidas por el DIH. EL CICR ha aclarado que no se requiere la materialización del daño sino simplemente la probabilidad objetiva de que el daño alcance el umbral. (Fiscalia, 2015)

En el mismo sentido, la doctrina operacional vigente ${ }^{9}$, ha señalado que cuando los civiles llevan a cabo un acto que se configura como participación directa en las hostilidades, pierden su calidad de persona protegida a pesar de no tener una función continua de combate como la de los miembros de Fuerzas Armadas (Huertas, 2008). Cuando la participación es temporal, la protección se pierde únicamente por el tiempo que dure tal participación, en relación con el Umbral de Daño señaló:

Umbral del Daño: debe existir un acto que afecte de manera adversa las operaciones o la capacidad militar de una de las partes en conflicto o que, de manera alternativa, cause muerte, lesiones destrucción a personas u objetos protegidos de ataques directos (Manual FFMM, 2015).

Posición derivada además de lo señalado por el CICR de la sentencia C291 de 2007 de la Corte donde se estipula:

Cuando las personas civiles o fuera de combate asumen una participación directa en las hostilidades, pierden las garantías provistas por el principio de distinción, únicamente durante el tiempo que dure su participación en el conflicto. Así lo establece a nivel convencional el artículo 13-3 del Protocolo Adicional II, en virtud del cual "las personas civiles gozarán de la protección que confiere este Título, salvo si participan directamente en las hostilidades y mientras dure tal participación (Sentencia C291, 2007)

Además de lo anterior, al tenor del CICR, cualquier acto desarrollado por un civil de manera voluntaria, que este orientado a menoscabar la capacidad logística y militar de la parte en contienda puede ser considerada suficiente para alcanzar el umbral pretendido, un sabotaje

\footnotetext{
${ }^{9}$ Manual de Derecho Operacional, Manual FF.MM. 3-41 Público, Segunda Edición, 2015
} 
en las comunicaciones, dar cuenta de la ubicación de una unidad que se desplaza por un terreno o impedir mediante manobras engañosas o fraudulentas que una unidad militar se ubique en un sector estratégico puede hacer perder la protección si se suma a esto el nexo beligerante y la causalidad directa.

También se podría alcanzar el concepto Umbral desarrollado por (Melzer, 2010), cuando se causen lesiones o ataques contra la unidad militar o los civiles protegidos, en estos casos, las actuaciones realizadas los milicianos podrían contribuir a alcanzar el requisito aludido, envenenar el agua donde se abastece la tropa acantonada en determinado sector, sembrar artefactos explosivos improvisados en las vías por donde se sabe caminan los soldados, constituyen actos que podrían indicar de acuerdo con la situación particular prevista la posibilidad de utilizar la fuerza legítima en la medida que se cumplan con la causalidad directa y el nexo beligerante.

Frente a la causalidad directa, el CICR dispone que; "para cumplir el requisito de causal directa, debe haber un vínculo causal directo entre el acto y el daño que pueda resultar de ese acto o de la operación militar coordinada de la que el acto constituya parte integrante. (Melzer, 2010, pág. 51)

Este requisito se cumple al tenor de la fiscalía, "si se puede esperar razonablemente que la acción hostil constituirá un daño que alcance el umbral requerido" (Fiscalia, 2015), en otras palabras: "debe existir un nexo causal directo entre el acto y el daño, el cual puede resultar directamente del acto o de una operación militar coordinada en la que este acto se constituye en parte integral" (Manual FFMM, 2015).

Dentro de estas actuaciones que podrían ser consideradas para interpretar este requisito acumulativo, están aquellas relacionadas directamente con la conducción de las hostilidades, allí varios aspectos pueden contribuir desde la perspectiva operacional a identificar aquellos casos que cumplen con lo planteado por el CICR, en ese sentido existen algunas posturas que surgen de la interpretación doctrinal que se ha hecho en el seno de la justicia militar que podrían contribuir a entender el punto analizado, al respecto en la revista especializada se indicó: 
El segundo requisito acumulativo recibe el nombre de causalidad directa, y se comprueba desde la perspectiva de la conducción de las hostilidades, en donde están enmarcadas aquellas actividades que contribuyen de manera eficaz al esfuerzo principal de la confrontación, es decir, todas aquellas tareas que conllevan la derrota del adversario, en especial las que guardan una proximidad temporal y geográfica y hacen parte de una operación concreta y coordinada, como la identificación de objetivos, la guía de artefactos explosivos improvisados lanzados contra una estación de policía (cilindros bomba), lo cuales en algunas poblaciones del Cauca son lanzados incluso desde las mismas viviendas del casco urbano, o el transporte de municiones o explosivos para aprovisionar el frente de combate por parte de conductor vestido de civil, e incluso, los escudos humanos voluntarios que con su presencia pretenden impedir el ataque o la defensa efectiva de una posición, siempre y cuando en todos los casos se analice la ventaja militar concreta, que puede resultar de la neutralización del blanco (Sarache, 2014).

Del examen anterior se observa que la causalidad directa viene acompañada de la necesidad de identificar la actuación desarrollada por aquel de quien se sospecha es participe activo de las hostilidades, el animus domini debe estar directamente relacionado con el fin perseguido, la cualificación y cuantificación de los perjuicios esperados y la cercanía con la probabilidad de la materialización del acto ilícito atribuido.

Esos elementos le dan al combatiente regular, las herramientas necesarias a la hora de analizar la posibilidad de hacer uso de la fuerza bélica en contra de una persona que se encuentra en las circunstancias mencionadas, siempre y cuanto reúnan los requisitos de umbral de daño y nexo beligerante, es importante recordar que ante la duda respecto de la actuación, no queda otro camino que abstenerse de procurar el ataque, así lo reconoce la doctrina operacional cuando se estipula:

¿Qué hacer en caso de duda? De conformidad con el artículo 50 del Protocolo I, siempre que exista una duda sobre la calidad de una persona, se entenderá que es civil. De ahí que si existe una duda sobre su pertenencia a un grupo armado organizado o sobre su participación directa en las hostilidades, también debe presumirse que la persona es civil y por lo tanto, evitar cualquier tipo de ataque (Manual FFMM, 2015, pág. 39).

Finalmente, "para que exista el requisito de nexo beligerante, el propósito específico del acto debe ser causar directamente el umbral de daño exigido en apoyo de una parte en conflicto menoscabando a otra" (Melzer, 2010, pág. 71).

En otras palabras, el acto deber ser planificado, concebido, dirigido a causar daño en la parte adversaria, acción que debe sobrepasar el umbral esperado, acciones como; la conducción de automóviles cargados con municiones o explosivos en el área de operaciones, la transmisión de inteligencia táctica en tiempo real para atacar a las propias tropas, el 
reclutamiento "ilícito" y entrenamiento de una persona para la ejecución de un acto hostil (Manual FFMM, 2015), pueden tener directa relación (nexo), con la actividad beligerante del GAO.

El nexo beligerante está relacionado con el propósito del acto, el cual debe estar orientado a lograr algún tipo de apoyo al GAO en detrimento de la fuerza militar, donde la actuación está dirigida a afectar los intereses de la fuerza militar y los bienes y recursos que hacen parte de la población civil, en cuyo caso el ataque es permitido incluso para aquellas personas que son obligadas a participar en las hostilidades (Sarache, 2014).

Es el caso de reclutamiento de menores, con quienes en muchas ocasiones se realizan atentados terroristas y activación de artefactos explosivos improvisados, estos menores pueden perder la protección ante un ataque directo, en cuyo caso, la responsabilidad sobre su neutralización debe recaer en forma exclusiva sobre el grupo que los obligó a tomar partido en la actividad criminal y se podrían atacar siempre y cuando la persona, en este caso el menor, no ignore totalmente la función que está desempeñando en la conducción de hostilidades, lo que en muchos casos es difícil de diferenciar, por tanto, lo mejor en esas circunstancias y ante la duda subsiguiente es acudir a los principios de proporcionalidad, necesidad militar, ventaja militar y distinción, antes de proferir cualquier tipo de agresión (Sarache, 2014).

En conclusión es dable afirmar que una persona que participa directamente en las hostilidades, pierde su protección contra ataques directos, hasta el momento en el que cesen sus actos hostiles en contra del adversario, mantiene su estatus de civil, no goza de los privilegios de un combatiente en sentido especifico, por ello en caso de captura, se le debe aplicar la normatividad interna por la acción desplegada y en la medida en que su actuación sea constante (función continua de combate), su papel ha mutado a combatiente en sentido genérico.

Esta denominación en modo alguno le otorga al GAO, condición de beligerancia (Artículo 3 Común), pero si lo lleva a perder su protección frente a ataques directos, en la medida que se determine su filiación constante al grupo, cualquier participación en las hostilidades en algunos casos no alcanza el umbral de daño requerido, su participación puede ser indirecta, en cuyo caso no pierde la protección de la que gozan los civiles y el marco jurídico aplicable de 
conformidad con el caso concreto debe ser sin duda el DIDH, allí, la neutralización o muerte debe ser la última opción, la captura y judicialización debe ser el objetivo primordial, allí la inteligencia estatal cobra un valor primordial, ya que el esfuerzo investigativo debe llevar a garantizar la vida e integridad sin renunciar a la posibilidad de ejercer el ius punendi ${ }^{10}$.

\subsubsection{Los civiles que participan indirectamente en las hostilidades}

Desde ya es importante afirmar que los civiles que participan de manera indirecta en las hostilidades no pueden ser considerados combatientes, mantienen su estatus incluso mientras desarrollan su participación, en palabras de la Comisión Interamericana de Derechos Humanos:

(...) las personas civiles que tan solo apoyen el esfuerzo militar o de guerra del adversario o de otra forma solo participen indirectamente en las hostilidades no pueden ser consideradas combatientes por esa única razón. Esto se debe a que la participación indirecta, tal como vender mercaderías a una o varias partes del conflicto, expresar simpatía por la causa de una o varias partes en el conflicto o, más claro aún, no haber actuado para prevenir la incursión de una de las partes en contienda, no implica actos de violencias que constituyan una amenaza inmediata de daño actual a la contraparte (Comisión Interamericana, 1999, pág. 96)

La participación indirecta deriva en la activación de la persecución penal en el marco del $\mathrm{DIDH}$, la fuerza letal no es una alternativa ya que hace parte de la población civil y con ello tiene una protección reforzada de cara al principio de distinción, lo anterior porque su participación no conlleva una acción directa en contra de la contraparte, su actuación esta orienta a brindar apoyo al esfuerzo militar de la parte simpatizante (Nieto, 2009, pág. 365), algunos ejemplos de su actuación son recopilados por la Fiscalía de la siguiente manera:

- Financiación de grupos armados organizados al margen de la ley

- Distribución de propaganda, proselitismo político en apoyo a los grupos armados organizados al margen de la ley.

- Suministro de alimentos, material de intendencia, comunicaciones. (Fiscalia, 2015, pág. 8)

\footnotetext{
10 “El ius puniendi del Estado ha sido definido como el poder que ostentan las autoridades, no sólo penales sino también administrativas, para el adecuado funcionamiento del aparato estatal. Siendo fiel a las palabras de la Corte, esta facultad se traduce en la "potestad ésta, que no sólo es ejercida por los jueces, sino por diversos funcionarios de la administración, que, para lograr el cumplimiento de las funciones que les han sido asignadas, deban hacer uso de éste, para garantizar el adecuado funcionamiento del aparato estatal" (Setencia C 160, 1998)
} 
Lo anterior porque los civiles que apoyan a los GAO, "aportando trabajo, transportando pertrechos, actuando como mensajeros o distribuyendo propaganda no pueden ser objeto de ataque directo individual, pero permanecen sujetos a la legislación doméstica" (Comisión Interamericana, 1999, pág. 96), o que voten o expresen simpática pública o privada por este tipo de estructura, siempre y cuando se contemple como ilícitas este tipo de conductas.

En virtud de lo anterior, independientemente de la denominación que le otorgue la Corte Constitucional (combatiente en sentido genérico), la doctrina y normativa internacional (Integrante de Grupo Armado), en los CANI solo pueden ser objeto de ataques directos aquellos miembros que desarrollan una función continua de combate, los civiles que participan directamente en las hostilidades pierden su protección siempre y cuando cumplan con los requisitos establecidos por el CICR mientras dure su participación y los Civiles que participan indirectamente, no pueden ser objeto de ataque directo, para ellos, se debe activar la ley penal y el marco aplicable es el DIDH.

\section{CONFLICTO ARMADO COLOMBIANO, MODOS Y MÉTODOS ASIMÉTRICOS PARA DESARROLLAR LA CONFRONTACIÓN ARMADA}

Después de analizar las diferentes formas de participar en las hostilidades, resulta oportuno a partir de este momento, estudiar los elementos constitutivos del conflicto armado, por cuanto entender esa denominación, permite activar el marco jurídico correspondiente. Para cumplir con dicha premisa, es necesario analizar la normatividad interna en la cual se ha reconocido la existencia del conflicto armado, además de las decisiones que han surgido en los órganos nacionales e internacionales de administración de justicia.

En el mismo sentido resulta conveniente estudiar el contenido y alcance de los principios del DIH iniciando con el de distinción, núcleo esencial de DIH, con lo cual se contribuye a resaltar la dificultad que existe para el miembro de la fuerza pública que desarrolla la función en el teatro de operaciones, cuando debe hacer uso de la fuerza, su especial comprensión permite otorgar a todos los intervinientes en el estudio de las consecuencias de una confrontación armada, aplicar además del marco juicio correspondiente, los criterios propios de las vicisitudes presentes en un conflicto asimétrico. 
Particularidad evidente en el caso colombiano, donde diariamente se presentan víctimas como consecuencia del uso indiscriminado de medios y métodos no convencionales $\mathrm{y}$ proscritos por el DIH, minas antipersonales, cilindros bomba, tacutos, carros bomba, son solo algunos de los instrumentos de guerra utilizados por los grupos armados para equiparar la balanza en el campo de combate, lo cual también será objeto de análisis de cara a la finalidad pretendida con la presente argumentación.

\subsection{Elementos esenciales para la denominación del conflicto armado}

Hasta la sanción de la ley 1448 de 2011, en Colombia siempre se había discutido sobre la existencia o no de un conflicto armado, muy a pesar de la existencia de condiciones objetivas, el gobierno de turno siempre había morigerado el lenguaje utilizando términos peyorativos como: "amenaza terrorista", " narcotraficantes", bandas de forajidos y otras descalificaciones que pretendían darle un alcance diferente a la denominación aludida, situación que dificultaba el papel de interpretación del operador judicial que tenía una dicotomía en cuanto a la aplicación o no de las normas del DIH (Restrepo, 2005, pág. 197).

Cumpliendo con el principio de libertad de configuración legislativa, el legislador atendió el llamado del gobierno de turno que presentó la respectiva norma para que fuera debatida en el seno del instituto bicameral, zanjó la discusión al reconocer con el nombre adecuado la situación que los colombianos han padecido en décadas de confrontación armada, en la mencionada norma se dispuso:

Artículo 3o. Víctimas. Se consideran víctimas, para los efectos de esta ley, aquellas personas que individual o colectivamente hayan sufrido un daño por hechos ocurridos a partir del 1o de enero de 1985, como consecuencia de infracciones al Derecho Internacional Humanitario o de violaciones graves y manifiestas a las normas internacionales de Derechos Humanos, ocurridas con ocasión del conflicto armado interno (Senado, 2011). (Subrayado fuera del texto)

Bajo esa premisa, el gobierno nacional reconoció la existencia de un conflicto armado y con ello la posibilidad de que en el territorio colombiano, cuando se presenten las circunstancias objetivas atribuibles a dicho nivel de confrontación armada, el marco jurídico de interpretación sea el DIH, ello incluso quedo plasmado en la Constitución Política, artículo 221 recientemente reformado el cual en su inciso segundo señala: 
En la investigación y juzgamiento de las conductas punibles de los miembros de la Fuerza Pública, en relación con un conflicto armado o un enfrentamiento que reúna las condiciones objetivas del Derecho Internacional Humanitario, se aplicarán las normas y principios de este. Los jueces y fiscales de la justicia ordinaria y de la Justicia Penal Militar o Policial que conozcan de las conductas de los miembros de la Fuerza Pública deberán tener formación y conocimiento adecuado del Derecho Internacional Humanitario (Senado, 2015).

No obstante la anterior denominación, es importante mencionar que la determinación respecto de la existencia o no de un conflicto armado, depende directamente el operador judicial que analiza el caso concreto, frente al estudio del marco jurídico aplicable en un asunto que por competencia haya llegado a su conocimiento:

(...) determinación de si hay o no conflicto armado no depende de criterios subjetivos o del reconocimiento de un Gobierno o del Presidente de turno, sino de elementos objetivos consagrados en instrumentos internacionales, normas jurídicas y en pronunciamientos judiciales (Sánchez, 2011).

Al respecto corresponde al funcionario encargado de hacer cumplir la ley, como herramienta legítima del Estado en relación con el control social, ajustar las decisiones a los requisitos construidos en las decisiones internas, presentes en las decisiones de la Corte Constitucional, Corte Suprema de Justicia, Fiscalía y Procuraduría General de la Nación, elementos que se compilan de manera sucinta a continuación.

\subsubsection{Conflicto Armado en las decisiones de los órganos que materializan el Ius puniendi a nivel interno}

Al respecto resulta entonces importante mencionar algunos instrumentos que permiten interpretar el umbral de violencia necesario para catalogar la situación como un conflicto armado, iniciando para ello, con la jurisprudencia de la Corte Constitucional, la cual desde el reconocimiento expreso del DIH en el marco normativo interno, ha señalado que en Colombia existe un conflicto armado, al respecto cobra importancia la sentencia C221 de 1995 donde se indicó:

La obligatoriedad del derecho internacional humanitario se impone a todas las partes que participen en un conflicto armado, y no sólo a las Fuerzas Armadas de aquellos Estados que hayan ratificado los respectivos tratados. No es pues legítimo que un actor armado irregular, o una fuerza armada estatal, consideren que no tienen que respetar en un conflicto armado las 
normas mínimas de humanidad, por no haber suscrito estos actores los convenios internacionales respectivos, puesto que la fuerza normativa del derecho internacional humanitario deriva de la universal aceptación de sus contenidos normativos por los pueblos civilizados y de la evidencia de los valores de humanidad que estos instrumentos internacionales recogen. Todos los actores armados, estatales o no estatales, están entonces obligados a respetar estas normas que consagran aquellos principios mínimos de humanidad que no pueden ser derogados ni siquiera en las peores situaciones de conflicto armado (Sentencia C225, 1995).

Además de reconocer la existencia del conflicto armado, dispone la obligatoriedad de aplicación del DIH por parte de las partes en conflicto, no solo de los agentes estatales, sino también de las organización de facto, lo anterior por cuanto "en Colombia no sólo el derecho internacional humanitario es válido en todo tiempo sino que, además, opera una incorporación automática del mismo "al ordenamiento interno nacional, lo cual, por lo demás, es lo congruente con el carácter imperativo que, según ya fue explicado, caracteriza a los principios axiológicos que hacen que este cuerpo normativo integre el ius cogens" (Sentencia C225, 1995).

En el mismo sentido la Corte Constitucional señala que la aplicación del DIH en el marco normativo interno no depende de la denominación política que se haga, ya que:

(...) para efectos de la aplicación del Derecho Internacional Humanitario, la existencia de un conflicto armado se determina jurídicamente con base en factores objetivos, independientemente de la denominación o calificación que le den los Estados, Gobiernos o grupos armados en él implicados. También cabe subrayar que la existencia de un conflicto armado "no surtirá efectos sobre el estatuto jurídico" de los grupos armados (Art. 3 Común). Una condición para el reconocimiento de insurgencia o beligerancia es que el grupo armado irregular haya aceptado y aplicado el DIH" (Sentencia C291, 2007).

Lo cual contribuye a asegurar, que las partes en conflicto deben respetar las normas del $\mathrm{DIH}$, mantener alejadas a la población civil de las consecuencias de la confrontación armada y utilizar en todo tiempo y lugar las precauciones contendidas en los principios del DIH, que contribuyen a minimizar las consecuencias de los actos hostiles en las personas más vulnerables, su aplicación y respeto no es reciproco, en palabras de la Corte Constitucional:

La obligación de respetar y de hacer respetar el derecho internacional humanitario no es de carácter sinalagmático o recíproco, es decir, su satisfacción por los Estados no depende del cumplimiento que le otorguen, a su vez, las otras partes enfrentadas en el conflicto. El carácter no recíproco de estas obligaciones se deriva directamente de la naturaleza fundamental de las normas y principios que mediante ellas se busca preservar, así como del hecho de que dichas obligaciones son erga omnes y por ende se adquieren frente a la comunidad internacional en su conjunto - punto que se explicará más adelante-. El carácter no recíproco de la obligación de 
respetar y hacer respetar el Derecho Internacional Humanitario adquirido a la fecha rango consuetudinario, habiendo sido reconocido en varias oportunidades por organismos internacionales de derechos humanos y tribunales internacionales (Sentencia C291, 2007).

De la misma manera, la Corte Suprema de Justicia en sede de casación, cuando analiza alguna conducta prevista en el título segundo de la ley 599 de 2000 (código penal), ha resaltado la diferencia entre combate y conflicto armado, el primero como una parte que conforma el todo, en ese sentido ha señalado que: "el combate, conforme lo ha expresado la Sala en múltiples determinaciones (...) comporta una acción militar entre bandos opuestos determinable en tiempo y espacio” (Sentencia Corte Suprema, 2010, pág. 31)

Es decir el combate es una consecuencia natural del conflicto armado, pero su análisis de manera aislada no permite activar la categorización de los presupuestos requeridos por el DIH, es necesario interpretar el contexto de la confrontación armada analizando los componentes integrales que permiten señalar cuando este, contribuye efectivamente a cumplir con el objetivo previsto por la estructura u organización, es decir, constituye un curso causal de acción dentro de la actividad principal que motiva la lucha armada.

En torno al conflicto armado la Corte Suprema señaló:

El Conflicto armado, en cambio, es de mayor cobertura: en términos del artículo $1^{\circ}$ del Protocolo Adicional II a los Convenios de Ginebra de 1949, corresponde al enfrentamiento al interior de un Estado entre sus fuerzas armadas y fuerzas armadas disidentes o grupos armados organizados, o entre éstos entre sí, que bajo la dirección de un mando responsable, ejerzan sobre una parte de dicho territorio un control tal que les permita realizar operaciones militares sostenidas y concertadas (Sentencia Corte Suprema, 2010).

En ese contexto al tenor de la Corte Suprema:

(...) el conflicto armado se desarrolla a través de distintas manifestaciones, una de ellas el combate entre las fuerzas armadas que protagonizan las hostilidades, no siendo esa su única forma de materialización. Así, las acciones militares "sostenidas y concertadas" incluyen labores de patrullaje y todas aquellas dirigidas a ejercer control sobre ciertos sectores de la población o la restricción de su movilización, entre otras, siendo a partir de la constatación de su presencia que puede predicarse precisamente la existencia de un control territorial" (Sentencia Corte Suprema, 2010).

En ese mismo sentido se pronunció al señalar la importancia de la interpretación restrictiva de cara al título II del código penal, la limitación existente para adecuar una 
situación fáctica concreta a los presupuestos jurisprudenciales previstos en los diferentes pronunciamiento de los tribunales Adhoc, al tenor de la corporación constituye, sumado al ordenamiento interno, en la mejor herramienta que tiene el operador judicial en el proceso de construcción de los hechos jurídicamente relevantes, en ese sentido dispuso:

(...) Para la aplicación de los delitos tipificados en el Título II de la parte especial del Código Penal de 2000, se requiere, en primer lugar, la concurrencia de un elementos normativo especial, a saber, la existencia de una situación que pueda ser calificada como 'conflicto armado' no internacional, porque todos los tipos penales allí consagrados requieren que la conducta se ejecute en desarrollo o con ocasión del mismo. [...]

No desconoce la Sala que el reconocimiento de la existencia de un conflicto armado es un acto político de complicadas consecuencias, que no corresponde declarar a la judicatura, pero esa situación no impide que ... el operador judicial, al momento de investigar y juzgar las conductas que pueden encajar en las descripciones típicas de los "delitos contra personas y bienes protegidos por el derecho internacional humanitario", verifique la existencia de esa situación en aras de salvaguardar los valores protegidos por el derecho internacional humanitario, que están por encima de cualquier consideración política.

En este sentido, la verificación judicial de que ciertos comportamientos se encuentran vinculados con el conflicto armado, se halla legitimada en el contexto de la Ley 975 de 2005, precisamente porque el acto político ya ha sido consignado expresamente dentro de los fundamentos de la norma, en particular, cuando allí se establecen como fines de la misma la consecución de la paz y la reconciliación nacional, significando de entrada que la desmovilización que allí se consagra opera respecto de miembros de grupos armados al margen de la ley, cuyo accionar no podría desvincularse del D.I.H (Sentencia Corte Suprema, 2010).

Además de los pronunciamientos antes citados, la Fiscalía General de la Nación también ha fijado para sus funcionarios las directrices pertinentes a la hora de estudiar una situación que reúna las condiciones objetivas previstas para el conflicto armado, en ese sentido se destaca la ya citada Directiva 003 de 2015, resulta evidente su reiterada mención en la presente argumentación, lo cual no debe interpretarse como una ausencia de fuentes de consulta, por el contrario, lo que se pretende es realzar la importancia de este documento de cara al papel que cumplen los fiscales a lo largo y ancho del territorio nacional, su interpretación desde la perspectiva del $\mathrm{DIH}$, constituye una garantía adicional para el cumplimento de la misión por parte de los soldados y policías que a diario arriesgan su vida, en especial por la debilidad que hoy tiene el fuero penal militar en el contexto nacional e internacional.

Para la fiscalía (Comisión, 2002). La existencia de un conflicto armado en Colombia es un hecho notorio, y por ello los fiscales no deberán probar en cada caso la existencia del mismo, 
pero si su relación o nexo causal. Porque es un hecho notorio, la leyes citadas permiten sustentar esa afirmación encontrada en el instrumentos de caracterización, además concluye que la aplicación del DIH no depende de la duración de la confrontación armada, ya que es evidente que en Colombia confluyen los dos cuerpos normativos (DIH y DIDH) y su activación depende del criterio definitorio de su utilidad, por cuanto se trata de una lex specialis $^{11}$. En palabras de la Fiscalía:

(...) el conflicto armado en Colombia es un hecho notorio, y por esta razón, para la imputación de los crímenes de guerra, los fiscales no requieren probar en cada caso concreto la existencia del conflicto armado, peros si deberán demostrar que la conducta se relaciona con el mismo. Así mismo, se debe aclara que la existencia de un conflicto armado no depende de su extensión temporal, y por lo tanto, que la activación del DIH puede darse por corto periodos de tiempo (Fiscalia, 2015, pág. 3).

Cuidado que se predica cuando surge una noticia criminal en donde se reúnan las condiciones objetivas para determinar cuándo estamos frente a un conflicto armado, así por ejemplo, la muerte que sufre un campesino que transita por un camino veredal y es alcanzado por un artefacto explosivo improvisado, sin duda constituye un homicidio en persona protegida, un crimen de guerra que se debe caracterizar como tal de conformidad con lo señalado en el Artículo 135 de la ley penal, no sucederá lo mismo si la muerte surge en condiciones disimiles; un campesino que tiene una riña a machete con un miembro armado de las FARC por una disputa personal de una herencia, este último le causa la muerte durante la riña, ello si bien es cierto implica el desarrollo de una investigación, no puede ser considerado homicidio en persona protegida, porque no comporta el nexo causal exigido para la imputación jurídica del resultado (Serrano, 2014).

También la Procuraduría en claro mensaje a sus funcionarios que deben analizar conductas disciplinarias realizadas por los miembros de la fuerza pública, por ejemplo las

\footnotetext{
${ }^{11}$ la Comisión Interamericana de Derechos Humanos ha advertido que "en situaciones de conflicto armado se aplica el derecho internacional de los derechos humanos y el derecho internacional humanitario", y que "en situaciones de conflicto armado, el derecho internacional humanitario puede servir como lex specialis para interpretar y aplicar los instrumentos internacionales de derechos humanos. (...) En tales circunstancias, es imprescindible examinar y aplicar los estándares definitorios y las normas relevantes del derecho internacional humanitario como fuente de orientación autorizada para evaluar el respeto de los instrumentos interamericanos en situaciones de combate (Comisión, 2002).
} 
contempladas en el artículo $48-7$ de la ley 734 de $2002^{12}$, difundió la Directiva 016 del 14 de octubre del 2010, según la cual:

En materia disciplinaria existe un tipo penal y autónomo que permite al operador disciplinario, de acuerdo con el recaudo probatorio, enmarcar la conducta de homicidio, como infracción al $\mathrm{DIH}$, porque es cometido en quien tiene la calidad de persona protegida, y en consecuencia, cuando se califique un homicidio de esta forma, el tipo disciplinario que debe traerse como referente normativo en el numeral 7 del artículo 48 de la ley 734 y no el numeral 1 de la misma norma pues este último enviaría por remisión normativa al artículo 135 del código penal, lo cual desconocería la especialidad y autonomía ya señaladas (Procuraduría, 2010, pág. 6).

Y en relación con la noción de conflicto interno, como eje temático esencial para unir la falta disciplinaria con la infracción al DIH citando la doctrina del CICR, señaló:

Los conflictos armados no internacionales son enfrentamientos armados prolongados que ocurren entre fuerzas armadas gubernamentales y las fuerzas de uno o más grupos armados, o entre estos grupos, que surgen en el territorio de un Estado parte en los convenido de Ginebra. EL enfrentamiento armado debe alcanzar un nivel mínimo de intensidad y las partes que participen en el conflicto deben poseer una organización mínima” (Procuraduría, 2010, pág. 3).

Herramienta indispensable que permite dentro del proceso de adecuación típica, ajustar la falta gravísima endilgada al servidor público, a un hecho que guarda relación con el conflicto y que amerita entonces la intervención del ente sancionador, investigación que en la mayoría de los casos se adelanta a la par con la causa penal, sin que ello constituya la violación del principio de doble incriminación, en atención que cada una persigue un fin diverso (Barja, 2004).

Además de la Fiscalía, Procuraduría, Altas Cortes, normatividad interna, también cobra relevancia los elementos configurativos del conflicto armado que surgen de los Tribunales Internacionales de Justicia, tanto los Tribunales Ad hoc, como los órganos multilaterales, que han constituido interesantes precedentes que desde la interpretación de las situaciones en las cuales han intervenido, permiten al operador judicial o al interviniente en la causa penal, solicitar la aplicación el marco jurídico adecuado, en especial todo lo relacionado con las causales objetivas prevista para el conflicto armado y su componente normativo DIH.

\footnotetext{
${ }^{12}$ Artículo 48 - 7. Incurrir en graves violaciones al derecho internacional humanitario.
} 


\subsubsection{Denominación del conflicto armado en los pronunciamientos de los Tribunales Internacionales de Justicia}

En el seno de las Naciones Unidas y de las organizaciones multilaterales como la Organización de los Estados Americanos (OEA), existen tribunales de justicia como es el caso de la Corte Interamericana de Derechos Humanos (CIDH) o la Corte Penal Internacional (CPI), creados por los estados parte para investigar casos de violaciones al DIDH o infracciones al DIH, ocurridas en el territorio de una alta parte contratante, de manera supletoria y cuando no se ha querido o no se ha podido administrar justicia (Mejia J. , 2009).

En el caso de la CPI, investiga y juzga de manera subsidiaria personas naturales mayores de dieciocho años que hayan cometido conductas punibles de competencia del estatuto (Kai Ambos, 2008, pág. 90), la Corte Constitucional al analizar los crímenes de competencia del Estatuto de Roma señaló que su finalidad es:

Determinar la responsabilidad penal individual de las personas que hayan cometido graves violaciones a los Derechos Humanos y al Derecho Internacional Humanitario, por lo que puede investigar y enjuiciar los crímenes de genocidio, de lesa humanidad, de guerra y el de agresión, cuando los Estados Parte no hayan cumplido con su deber de perseguir, juzgar y castigar a los responsables de dichos crímenes dentro de sus respectivas jurisdicciones (Sentencia C240, 2009).

Por su parte la CIDH, le corresponde determinar las responsabilidades de los Estados por violaciones a las disposiciones contenidas en al Convención Americana de Derechos Humanos, partiendo de la premisa que el DIH solo lo usa como fuente para la interpretación de las obligaciones convencionales ${ }^{13}$.

Partiendo de esa premisa, la intervención que se realiza con posterioridad a la afectación, ha configurado la construcción de Tribunales Internacionales orientados a la sanción de personas naturales o jurídicas que han cometido delitos contra la humanidad o ha tolerado su comisión, actuación que en materia penal no vulnera el principio de legalidad, ello quedo sentado en la decisiones del Tribunal de Nuremberg las cuales fueron consideradas ajustadas a la ley porque:

\footnotetext{
${ }^{13}$ En ese sentido ver la sentencia de fondo reparaciones y costas que se tomó por parte de la CIDH en el Caso de la Masacre de Santodomingo Vs Colombia el 30 de noviembre de 2012. Disponible en:

http://www.corteidh.or.cr/cf/jurisprudencia2/ficha_tecnica.cfm?nld_Ficha=237\&lang=es
} 
El Tribunal Militar Internacional ha establecido que los crímenes de guerra eran expresiones del derecho internacional existentes al momento de la creación del tribunal en 1945, mientras que la carta del tribunal debe considerase declarativa de los principios del derecho internacional en vista de su reconocimiento como tal por parte de la asamblea general de las Naciones Unidas (Fiscalia, 2015, pág. 29).

En ese contexto, aparecen diferentes decisiones de los tribuales activados con ocasión de hechos notorios, que sin duda cambiaron la historia de la humanidad o de en las regiones de su influencia para siempre. Es el caso del Tribunal de Nuremberg, Tribunal de Tokio, el Tribunal Penal Internacional para la ex-Yugoslavia (en adelante TPIY), el Tribunal Penal Internacional para Ruanda (en adelante TPIR), Corte Penal Internacional (en adelante CPI) y Corte Interamericana de Derechos Humanos (en adelante CIDH).

Frente a lo anterior resulta preciso señalar que si bien es cierto al CIDH no es un tribunal penal internacional, es decir no juzga personas naturales como si lo hacen los otros tribunales, en sus decisiones ha generado una posición según la cual ${ }^{14}$ los organizamos encargados de la persecución de los crimen de guerra o crímenes contra la humanidad deben investigar y juzgar a los responsables de estas conductas (Acosta, 2005).

De los tribunales mencionados, algunos pronunciamientos resultan relevantes para comprender el alcance y contenido del conflicto armado, a continuaciones entonces, se citaran algunos de esos mandatos, que constituyen desde la perspectiva del soft law, fuente de interpretación relevante en las decisiones y actuaciones de los funcionarios encargados de hacer cumplir la ley, los particulares con injerencia en el contexto del conflicto y los combatientes en sentido genérico.

Partiendo de esa premisa y compilando el derrotero efectuado por la Corte Constitucional en la Sentencia C291 de 2007, los tribunales internacionales antes citados, señalan que el estudio de los elementos del conflicto armado, cuando se trata de analizar el marco normativo relevante en un caso concreto debe realizarse no en abstracto, sino teniendo en cuenta cada caso en particular, en ese sentido se pronuncia el TPIR indicando:

\footnotetext{
${ }^{14}$ En ese sentido ver entre otras decisiones: Caso Masacre de Santodomingo Vs Colombia; Caso Masacre de las Palmeras Vs Colombia; Caso 19 comerciantes Vs Colombia.
} 
(...) la definición de un conflicto armado per se se formula en abstracto; el que una situación pueda o no ser descrita como un "conflicto armado" que satisface los criterios del Artículo 3 Común, ha de decidirse en cada caso concreto ${ }^{15}$ (Setencia TIPR, 1999).

Ahora, para establecer teniendo en cuenta la premisa anterior, (en el caso concreto), si el hecho ha cruzado el umbral necesario de violencia para ser determinado como un CANI, señala la Corte (sentencia C291) citando a los tribunales internacionales que se deben tener en cuenta dos criterios: a. la intensidad del conflicto y b. el nivel de organización de las partes, en ese sentido se ha pronunciado el TPIY en el caso Tadic:

Bajo este test, al establecer la existencia de un conflicto armado de carácter interno la Sala debe apreciar dos criterios: (i) la intensidad del conflicto y (ii) la organización de las partes (Tadic, par. 562). Estos criterios se utilizan 'solamente para el propósito, como mínimo, de distinguir un conflicto armado de actos de delincuencia, insurrecciones desorganizadas y de corta duración, o actividades terroristas, que no están sujetas al Derecho Internacional Humanitario' [sentencia del caso Tadic, par. 562]. (...) En consecuencia, un cierto grado de organización de las partes será suficiente para establecer la existencia de un conflicto armado. (...) Esta posición es consistente con otros comentarios autorizados sobre el tema. Un estudio por el CICR sometido como documento de referencia a la Comisión Preparatoria para el establecimiento de los Elementos de los Crímenes para la CPI notó que: 'La determinación de si existe un conflicto armado no internacional no depende del juicio subjetivo de las partes a ese conflicto; debe ser determinado con base en criterios objetivos; el término 'conflicto armado' presupone la existencia de hostilidades entre fuerzas armadas organizadas en mayor o menor medida; debe haber oposición por las fuerzas armadas, y una cierta intensidad de los combates ${ }^{16}$.(...) (TIPY, 2005)

\footnotetext{
15 "Traducción informal: "The definition of an armed conflict per se is termed in the abstract, and whether or not a situation can be described as an "armed conflict", meeting the criteria of Common Article 3 , is to be decided upon on a case-by-case basis". Tomado de manera literal de: http://www.corteconstitucional.gov.co/relatoria/2007/C-291-07.htm\#_ftn37 fecha de consulta: 12 de julio de 2016. Formato web

16 "Traducción informal: "Under this test, in establishing the existence of an armed conflict of an internal character the Chamber must assess two criteria: (i) the intensity of the conflict and (ii) the organisation of the parties.[See Tadic Trial Judgement, para 562. ]These criteria are used "solely for the purpose, as a minimum, of distinguishing an armed conflict from banditry, unorganized and short-lived insurrections, or terrorist activities, which are not subject to international humanitarian law." [Tadic Trial Judgement, para 562.] (...) Therefore, some degree of organisation by the parties will suffice to establish the existence of an armed conflict. (...)This position is consistent with other persuasive commentaries on the matter. A study by the ICRC submitted as a reference document to the Preparatory Commission for the establishment of the elements of crimes for the ICC noted that: The ascertainment whether there is a non-international armed conflict does not depend on the subjective judgment of the parties to the conflict; it must be determined on the basis of objective criteria; the term 'armed conflict' presupposes the existence of hostilities between armed forces organised to a greater or lesser extent; there must be the opposition of armed forces and a certain intensity of the fighting.(...)" Tomado de manera literal de: http://www.corteconstitucional.gov.co/relatoria/2007/C-291-07.htm\#_ftn37 Fecha de consulta: 12 de julio de 2016. Formato web.
} 
En relación con el primer elemento, es decir la intensidad del conflicto, la Corte Constitucional citando a los tribunales internacionales ${ }^{17}$ señaló que se puede tener en cuenta la seriedad de los ataques y si ha habido un incremento en las hostilidades.

La seriedad de los ataques y el incremento de las hostilidades, permite distinguir un hecho concreto en relación con el conflicto, de un hecho atribuible a delincuencia común, varias situaciones presentadas por ejemplo en las comunas de la ciudad de Medellín en los últimos años, presentan características asimilables a los requisitos citados, pero no alcanzan el umbral de violencia necesario para ser catalogado como hecho del conflicto, si bien es cierto se presentan confrontaciones entre combos delincuenciales, los integrantes de estas estructuras no alcanzan a ser denominados como combatientes en sentido genérico y por ello no pierden su protección frente a ataques directos (Salazar \& Jaramillo, 1992).

La interpretación entonces se realiza en sentido restringido, al tenor del TIPY:

La historia de la redacción del Artículo 3 Común provee una guía adicional. Varias propuestas en borrador de lo que más tarde sería conocido como el Artículo 3 Común buscaban hacer que su aplicación dependiera, inter alia, de condiciones tales como un reconocimiento explícito de los insurgentes por el gobierno de jure, la admisión de la disputa a la agenda del Consejo de Seguridad o la Asamblea General de las Naciones Unidas, la existencia de una organización semi-Estatal de los insurgentes, y de autoridades civiles ejerciendo poderes de facto sobre personas en determinados territorios. Sin embargo, ninguna de estas condiciones fue incluida en la versión final del Artículo 3 común que fue objeto de acuerdo por los Estados Parte en la Conferencia Diplomática. Ello provee una clara indicación de que los redactores de las Convenciones de Ginebra no quisieron incluir tales requisitos explícitos para la aplicación del Artículo 3 Común. La Sala también es consciente del Artículo 8 del Estatuto de la Corte Penal Internacional (...). Un comentario al Estatuto de la CPI sugiere, más aún, que factores adicionales tales como el involucramiento de las fuerzas gubernamentales de un lado, o el ejercicio de control territorial por las fuerzas rebeldes, no son indispensables para la determinación de un conflicto armado ${ }^{18}$. (TIPY, 2005)

\footnotetext{
17 "Ver, entre otros, los casos Fiscal v. Dusko Tadic, No. IT-94-1-AR72, decisión de la Sala de Apelaciones sobre su propia jurisdicción, 2 de octubre de 1995; Fiscal vs. Fatmir Limaj y otros, sentencia del 30 de noviembre de 2005; Fiscal vs. Zejnil Delalic y otros (caso Celebici), sentencia del 16 de noviembre de 1998" Tomado de manera literal de: http://www.corteconstitucional.gov.co/relatoria/2007/C-291-07.htm\#_ftn37 Fecha de consulta: 12 de julio de 2016. Formato web.

${ }^{18}$ Traducción informal: "The drafting history of Common Article 3 provides further guidance. Several proposed drafts of what later became known as Common Article 3 sought to make its application dependant, inter alia, on conditions such as an explicit recognition of the insurgents by the de jure government, the admission of the dispute to the agenda of the Security Council or the General Assembly of the United Nations, the existence of the insurgents' State-like organisation, and civil authority exercising de facto authority over persons in determinate territory. However, none of these conditions was included in the final version of Common Article 3, which was actually agreed by the States Parties at the Diplomatic Conference. This provides a clear indication
} 
Frente a la intensidad de la confrontación armada, presupuesto indispensable para la catalogar además de la existencia del grupo armado, el nivel de violencia necesario, en la directiva del Ministerio de Defensa Nacional 015 de 2016, citando al TIPY, en su fallo Ljube Boskoski y Johan Tarculovski ${ }^{19}$, se indican a manera de ejemplo los siguientes elementos:

- La seriedad de los ataques y su incremento en cantidad o la dispersión en el territorio.

- La propagación de los enfrentamientos en un territorio y en un período de tiempo determinado.

- El incremento en el pie de fuerza de las Fuerzas Militares de un país, la movilización y distribución de armamento.

- La atención internacional que el conflicto haya recibido.

- El tipo de armamento empleado, la utilización de equipos militares, el bloqueo o el asalto a ciudades y la extensión de su destrucción.

- El número de víctimas resultantes de ataques.

- El número de tropas y unidades desplegadas.

- La ocupación de un territorio, de ciudades y pueblos.

- El despliegue de las FF.MM. a las áreas críticas.

- El cierre de carreteras. (Ministerio de Defensa, 2016)

Todo lo anterior permite en especial al operador judicial, realizar un análisis objetivo de la situación puesta a su conocimiento, interpretar los hechos de cara al marco jurídico pertinente (DIH), y con base en el resultado de su averiguación, establecer si las circunstancias propias en las cuales se desenvuelve lo fáctico, se ajustan a los elementos objetivos citados, lo anterior porque:

La existencia de un conflicto armado es la circunstancia objetiva que permite la aplicación concreta del derecho internacional humanitario. Esto es, que dada la existencia de un conflicto armado existe un deber internacional de aplicar las normas del derecho internacional humanitario, a título de normas convencionales o consuetudinarias (Pinto, 2003).

Con lo anterior podemos señalar que los elementos objetivos que permiten determinar cuándo una situación es asimilable a un conflicto armado son; la intensidad del conflicto y el nivel de organización de las partes. Determinar la existencia del conflicto permite la aplicación

that no such explicit requirements for the application of Common Article 3 were intended by the drafters of the Geneva Conventions. // 87. The Chamber is also conscious of Article 8 of the Statute of the International Criminal Court (...). A commentary on the ICC Statute further suggests that additional factors, such as the involvement of government forces on one side or the exercise of territorial control by the rebel forces, are not indispensable for the determination of an armed conflict. (...)]Tomado de manera literal de: http://www.corteconstitucional.gov.co/relatoria/2007/C-291-07.htm\#_ftn37 Fecha de consulta: 12 de julio de 2016. Formato web.

${ }^{19}$ International Criminal Tribunal for the Former Yugoslavia (ICTY).The Prosecutor v LjubeBoskoskiand Johan Tarculovski. Judgment. IT-04-82-T. 10 de julio de 2008. Par.177 y 194. 
del DIH (Ius in bello), lo cual es relevante a la hora de planear y ejecutar operaciones en el teatro de los acontecimientos, además permiten entender de manera adecuada la actuación del militar o policía, y su judicialización en caso de que se presente una infracción a las costumbres de la guerra.

\subsection{El papel del combatiente de cara a los principios del DIH}

Con el fin de entender el papel del combatiente en los conflictos armados, es importante analizar tres principios del DIH que resultan relevantes de cara a la argumentación pretendida; distinción, proporcionalidad y necesidad militar, al estudiarlos se podrá entender la dificultad manifiesta que resulta de su aplicación en el contexto del conflicto interno y la responsabilidad penal atribuible a los miembros del grupo armado que de manera despreocupada o dolosa realizan, coordinan o dirigen ataques contra las personas o bienes protegidos por las leyes y costumbres de la guerra.

\subsubsection{Distinción}

El combatiente independiente de la denominación que asuma en cuanto al conflicto armado o al tribunal que estudie el caso, debe observar, acatar y cumplir en el desarrollo de su actuación el principio de distinción, el cual constituye el núcleo duro del DIH, por cuanto permite diferenciar entre los actores del conflicto y la población civil, la cual como premisa esencial siempre debe estar alejada de las consecuencias de las hostilidades (Rey, 2007).

En caso de su inobservancia o inaplicación deberá ser judicializado, al tenor de la Corte Constitucional: "cuando una de las partes en conflicto vulnera los principio de precaución, distinción e incurre en algún delito o crimen de guerra tipificado como tal en la legislación nacional. En este último momento, las autoridades judiciales deben utilizar las reglas del DIH antes citadas para integrar el proceso de adecuación típica al comportamiento e imputar las correspondientes infracciones a los autores o participes de la conducta" (Sentencia C084, 2016) . 
En ese contexto, diferenciar en el campo de combate quien es o no combatiente, permite adecuar los métodos y medios para hacer la guerra a las buenas costumbres internacionales, constituye una premisa esencial en relación con la posibilidad de aplicar el uso de la fuerza, especialmente en el marco jurídico del DIH, donde se permite hacer uso legítimo de las armas que el Estado proporciona para garantizar la defensa de sus instituciones en contra de aquellos que amenacen la estabilidad nacional.

Lo anterior implica que solamente se pueden atacar objetivos militares (Sentencia C291, 2007), en consecuencia las operaciones militares solo podrán estar dirigidas contra los combatientes en sentido genérico, o las personas que participan directamente en las hostilidades mientras dure su participación, y respecto de "aquellos objetos que por su naturaleza, ubicación, finalidad o utilización contribuyan eficazmente a la acción militar y cuya destrucción total o parcial, captura o neutralización ofrezca en las circunstancias del caso una ventaja militar definida" (Protocolo I Artículo. 52)

De manera general, el principio de distinción, implica que las partes en conflicto harán distinción en todo momento entre población civil y las personas que pueden ser lícitamente enfrentadas: a), miembros de los grupos armados organizados al margen de la ley GAOML y b), los civiles que toma parte directa de las hostilidades y mientras dure su participación; asimismo se debe diferenciar entre bienes de carácter civil y objetivos militares, y en consecuencia dirigirán sus operaciones únicamente contra objetivos militares (Manual FFMM, 2015, pág. 29)

Este principio tiene un alcance distinto en cada uno de los conflictos CAI o CANI, en los primeros la regulación está ligada a los presupuestos del artículo 48 del Protocolo I, norma que estipula:

Artículo 48. A fin de garantizar el respeto y la protección de la población civil y de los bienes de carácter civil, las Partes en conflicto harán distinción en todo momento entre población civil y combatientes, y entre bienes de carácter civil y objetivos militares y, en consecuencia, dirigirán sus operaciones únicamente contra objetivos militares. (Protocolo I, 1949)

Lo cual indica que la obligación esta únicamente en distinguir bienes y personas civiles de los objetivos militares, bajo esa premisa se podría en un CAI, atacar una instalación civil si su neutralización permite obtener una ventaja militar definida de cara al fin pretendido por la organización, lo cual en materia de los CANI es más restringido, la regulación normativa aplicable es el Articulo 3 común y el protocolo adicional II. 
Dicha restricción, limita la posibilidad de dirigir ataques intencionales contra la población civil o sus bienes, salvo si participan directamente en las hostilidades, lo anterior por cuanto el objetivo pretendido es el de minimizar las consecuencias de la guerra en la población civil y distinguir claramente entre quienes se pueden y quienes no atacar en una acto de guerra.

El Derecho Internacional Humanitario protege a la población civil y prohíbe los ataques contra civil o bienes de carácter civil. Una de sus reglas de juego es el principio de distinción: las partes en conflicto tienen la obligación de llevar a cabo operaciones militares exclusivamente contra objetivos militares; por lo tanto, deben distinguir entre civiles y combatientes, así como entre objetivos civiles y objetivos militares. El principio de distinción impone límites a los medios y a los métodos de guerra: está prohibida cualquier arma o estrategia que no puedan dirigirse exclusivamente contra un objetivo militar concreto (DFAE, 2014, pág. 27).

Lo que permite deducir como lo hiciera oficina en Colombia del Alto Comisionado de las Naciones Unidas para los Derechos Humanos, "uno de los principios fundamentales del derecho internacional humanitario es el de distinción entre quienes participan directa o directamente en las hostilidades y quienes en ellas no tienen esa participación. Aplicar tal principio resulta necesario para determinar las obligaciones y los derechos que corresponden a unos y a otros" (ONU, 2003)

Además señaló que la aplicación del principio de distinción obliga, entre otras cosas, a:

1. Garantizar a la población civil y a las personas civiles el trato humano y la protección general que les otorgan los instrumentos de derecho humanitario.

2. Asegurar a quienes se han rendido y a quienes han quedado fuera de combate el trato humano para ellos previsto por el derecho internacional humanitario.

3. Hacer efectivas las garantías previstas por el derecho humanitario para las personas privadas de la libertad por motivos relacionados con el conflicto (por ejemplo, darles un trato humano que incluya proporcionarles condiciones dignas de detención y no exponerlas a los peligros de la guerra).

4. Evitar ataques contra bienes que no son objetivos militares.

5. Facilitar las actividades emprendidas por las organizaciones humanitarias para atender a las víctimas del conflicto. (ONU, 2003)

La misma Corte, desarrolló en su jurisprudencia una línea orientada a garantizar el cumplimiento del principio de distinción en un conflicto asimétrico, esta fue recompilada en un instrumento de consulta denominado lucha con la impunidad de la Vicepresidencia de la República, el cual resulta pertinente traer de manera literal (Vicepresidencia, 2010, pág. 204): 
Las reglas del principio de distinción en la jurisprudencia de la Corte Constitucional

\begin{tabular}{|c|c|}
\hline \multicolumn{2}{|r|}{ Las reglas del principio de distinción en la jurisprudencia de la Corte Constitucional } \\
\hline $\begin{array}{l}\text { La prohibición de dirigir } \\
\text { ataques contra la } \\
\text { población civil }\end{array}$ & $\begin{array}{l}\text { - } \quad \text { Los ataques proscritos son aquellos en los que la población civil es el objetivo primario del ataque. } \\
\text { - } \quad \text { Para efectos de determinar si los ataques han sido dirigidos efectivamente contra una población civil la Corte destaca } \\
\text { algunos factores considerados por la jurisprudencia penal internacional, como: (i) los medios y métodos utilizados en el } \\
\text { curso del ataque, (ii) el número y el status de las víctimas, (iii) la naturaleza de los crímenes cometidos durante el ataque, } \\
\text { (iv) la resistencia a los atacantes durante el avance, y (v) la medida en la cual la fuerza atacante cumplió o intentó cumplir } \\
\text { con el principio de precaución del } \mathrm{DIH}^{49} \text {. } \\
\text { - No es necesario que el ataque sea dirigido contra la totalidad de la población civil de la entidad geográfica en la que } \\
\text { ocurren los hechos; pero sí debe probarse que el a taque no se dirigió contra un número limitado de individuos. } \\
\text { No es necesario que todos y cada uno de los miembros de esa población sean civiles es suficiente con que sea de } \\
\text { naturaleza predominantemente civil, y puede incluir, por ejemplo, individuos puestos fuera de combate }\end{array}$ \\
\hline $\begin{array}{c}\text { Prohibición de desarrollar } \\
\text { actos orientados a } \\
\text { aterrorizar a la población } \\
\text { civil }\end{array}$ & $\begin{array}{l}\text { - Es una especie de la prohibición general de dirigir ataques contra los civiles. } \\
\text { - Busca proteger a la población civil como un todo - o a civiles individuales - que no toman parte en las hostilidades, de } \\
\text { actos o amenazas de violencia perpetrados con el objetivo principal de generar terror. }\end{array}$ \\
\hline $\begin{array}{l}\text { Distinción entre bienes de } \\
\text { carácter civil y objetivos } \\
\text { militares }\end{array}$ & $\begin{array}{l}\text { - Es deber de las partes que participan en el conflicto armado distinguir entre objetivos militares y bienes civiles, } \\
\text { solamente se puede atacar lícitamente los objetivos militares }\end{array}$ \\
\hline $\begin{array}{l}\text { Prohibición de los ataques } \\
\text { indiscriminados y de las } \\
\text { armas de efectos } \\
\text { indiscriminados }\end{array}$ & $\begin{array}{l}\text { - Son indiscriminados los ataques: (i) que no están dirigidos contra un objetivo militar concreto; (ii) en los que se emplean } \\
\text { métodos o medios de combate que no pueden dirigirse contra un objetivo militar concreto; o (iii) en los que se emplean } \\
\text { métodos o medios de combate cuyos efectos no sea posible limitar, como exige el DIH; y que, en consecuencia, pueden } \\
\text { alcanzar indistintamente, en cualquiera de tales casos, tanto a objetivos militares como a personas civiles o bienes de } \\
\text { carácter civil. } \\
\text { - Los ataques de carácter indiscriminado no se justifican en ningún caso, ni siquiera cuando la población civil incluye } \\
\text { algunos elementos no civiles o la presencia de combatientes. } \\
\text { - Se prohíben usar armas incapaces de diferenciar entre bienes civiles y objetivos militares. }\end{array}$ \\
\hline $\begin{array}{l}\text { Prohibición de atacar los } \\
\text { bienes de supervivencia } \\
\text { de la población civil }\end{array}$ & $\begin{array}{l}\text { - Se traduce en dos proscripciones específicas (i) hacer padecer hambre a la población civil, y (ii) atacar, destruir, sustraer o } \\
\text { inutilizar los bienes indispensables para su supervivencia. }\end{array}$ \\
\hline $\begin{array}{l}\text { Prohibición de atacar a las } \\
\text { personas puestas fuera de } \\
\text { combate }\end{array}$ & $\begin{array}{l}\text { - El principio de distinción cobija tanto a las personas civiles y a la población civil, como también a las personas fuera de } \\
\text { combate, dentro de la categoría no combatientes. }\end{array}$ \\
\hline
\end{tabular}

Gráfica 3. Reglas del principio de distinción en la jurisprudencia de la Corte Constitucional

De lo anterior se puede concluir, que el principio de distinción cobra especial valor desde el proceso militar para la toma de las decisiones, las actuaciones de los miembros de la fuerza pública deben estar orientadas a garantizar la protección de todos los habitantes de las zonas de influencias de los GAO, bajo ese criterio solo se pueden ejecutar y planear las operaciones hacia los objetivos militares, nunca contra la población civil, lo cual en un conflicto asimétrico representa mucha dificultad.

Y es difícil porque los GAO generalmente utilizan dentro de sus estructuras personas que hacen parte de la población civil, aprovechan la cercanía a líderes sociales en sus zonas de 
influencia, bajo esa dinámica es posible encontrar un líder comunal de día, protestando por la presencia del ejército en determinada vereda y en la noche esa misma persona ya como combatiente hostigando con su AK47 a las mismas tropas en sus zonas campamentarias.

Según (Oficina del Alto Comisionado de las Naciones Unidas para Colombia, 2014) También es posible encontrar un menor de edad ${ }^{20}$, utilizado como miliciano, que se disfraza de campesino que atiende una labranza, el cual está realizando labores de inteligencia a determinada unidad militar o a la espera del paso de los soldados o policías para activar campos minados, áreas preparadas con explosivos llenos de metralla, aquellas acciones son en ocasiones muchos más lesivas que las que puedan desarrollar los combatientes en sentido genérico, el cual de manera permanente realizan actividades continuas de combate.

Entender esa dificultades desde un escritorio suele ser difícil, más aun cuando el interlocutor es una persona que no conoce la vida miliar, que no utiliza el marco jurídico correspondiente, además si quien explica es un ser tan vulnerable como un soldado analfabeta, pues ello sí que es complejo, explicarle a un Fiscal de Derecho Humanos; que se dio muerte a un menor que tenía en sus manos solamente una batería nueve voltios y que con ella iba a activar un campo minado, sin duda genera dificultades, especialmente por la desconfianza que existe en torno a la función y el fantasma de los mal llamados "falso positivos" que aun hoy por hoy siguen enlodando la actuación de las fuerzas militares y la policía nacional.

\subsubsection{Principio de Proporcionalidad}

El DIH contempla la posibilidad de ataques a la población civil bajo ciertos requisitos y solamente en el contexto de daños incidentales, siempre y cuando estos no sean excesivos en relación con la ventaja militar concreta esperada. Un civil podría resultar afectado debido a un error en la identificación del objetivo, o porque esta de manera inevitable cerca de un objetivo

\footnotetext{
20 “Innumerables hallazgos de la Fuerza Pública y de la Fiscalía sobre diarios secretos de las Farc, volantes de resistencia que circulaban de mano en mano entre la manigua, manuales para adoctrinar milicianos y protocolos de la guerrilla dejaron al descubierto la aberrante política de reclutamiento de niños para la guerra. Una constante que les permitió a las autoridades documentar 3.000 casos de menores recuperados de las filas subversivas en la última década. El 59\% de los infantes desvinculados del conflicto corresponden a las Farc. Y, en tiempos de diálogos y referendos en ciernes, con la Corte Penal Internacional vigilante, la justicia apura sus cuentas para redondear las cifras de este crimen de lesa humanidad". (Oficina del Alto Comisionado de las Naciones Unidas para Colombia, 2014)
} 
militar, en cuyo caso el ataque podara ser justificado en la medida que no sea intencional (Aguirre, 2002, pág. 60).

Dicho principio como lo citara la Fiscalía en la directiva 003 fue desarrollado por el TIPY, en el caso Stanislav Galic donde se dispuso:

La aplicación práctica del principio de proporcionalidad requieren que quienes planea o lanzan un ataque tomen todas las precauciones factibles para verificar que los objetivos atacados no son personas civiles ni bienes civiles, con el fin de evitar daños a civiles en la medida de lo posible. Una vez el carácter militar de un objetivo se ha verificado, los comandantes deben considerar si el ataque de ese objetivo es de prever que causara incidentalmente muertos y heridos entre la población civil, o daños a bienes de carácter civil, o ambas cosas, que serían excesivos en relación con la ventaja militar concreta y directa prevista. Si tales daños son de prever, el ataque no debe ser lanzado. La obligación básica de evitar daños a personas civiles y bienes civiles en cuento sea posible debe guiar a guiar a la parte que lanza el ataque a considerar la proporcionalidad del mismo. Al determinar si un ataque fue proporcional es necesario examinar si una persona razonablemente bien informada en las circunstancias del procesado, haciendo uso razonable de la información a su disposición, hubiera esperado que el ataque resultara en bajas civiles excesivas (TIPY, 2003, pág. 58).

Teniendo en cuenta lo anterior, es dable asegurar que estos daños son tolerados por las leyes de la guerra, siempre y cuando no sean excesivos de cara a la ventaja militar concreta pretendida, esa ventaja militar, es aquella consecuencia esperada por la acción en el adversario, dependerá entonces del objetivo perseguido, del éxito planteado y del resultado obtenido, el juicio de ponderación ex ante y ex post, es determinante para delimitar la consecuencias de las hostilidades y reprimir si es el caso, los daños resultantes cuando sea innecesarios o arbitrarios, en el desarrollo de la confrontación armada (Anaya, 2005, pág. 56).

Frente a la criminalización de comportamientos que puede constituir una infracción al $\mathrm{DIH}$, al analizar la situación fáctica, es posible recurrir a tres pasos fundamentales para determinar como lo señala la Fiscalía, la proporcionalidad o no de un ataque militar:

1. La existencia de una necesidad militar que justifique una operación proporcionalmente adecuada para obtener la ventaja esperada.

2. La obligación de que la pérdida de vidas y el daño a objetos civiles o protegidos no sea excesiva (esto implica una adecuada planeación de la acción militar y un uso adecuado y moderado del armamento y las municiones) 
3. Un balance entre el objetivo perseguido y la vulneración al principio de humanidad. El resultado debe justificar la razonabilidad del ataque. (Fiscalia, 2015, pág. 16)

Al tenor de lo anterior, el principio de proporcionalidad permite analizar el daño derivado de una acción militar, reducir las consecuencias de las acciones ofensivas presentadas en el desarrollo de operaciones coordinadas, permite asegurar desde el planeamiento que los ataques solamente estén dirigidos hacia la población civil y contemplar la posibilidad de daños colaterales o incidentales que puedan surgir ya sea porque se presentó un error en el objetivo, o como ya se señaló, por la cercanía y la ubicación del mismo, en ese contexto la Vicepresidencia en el programa de lucha contra la impunidad diseñó el siguiente cuadro que destaca la relevancia del principio en el marco de la compresión integral del DIH:

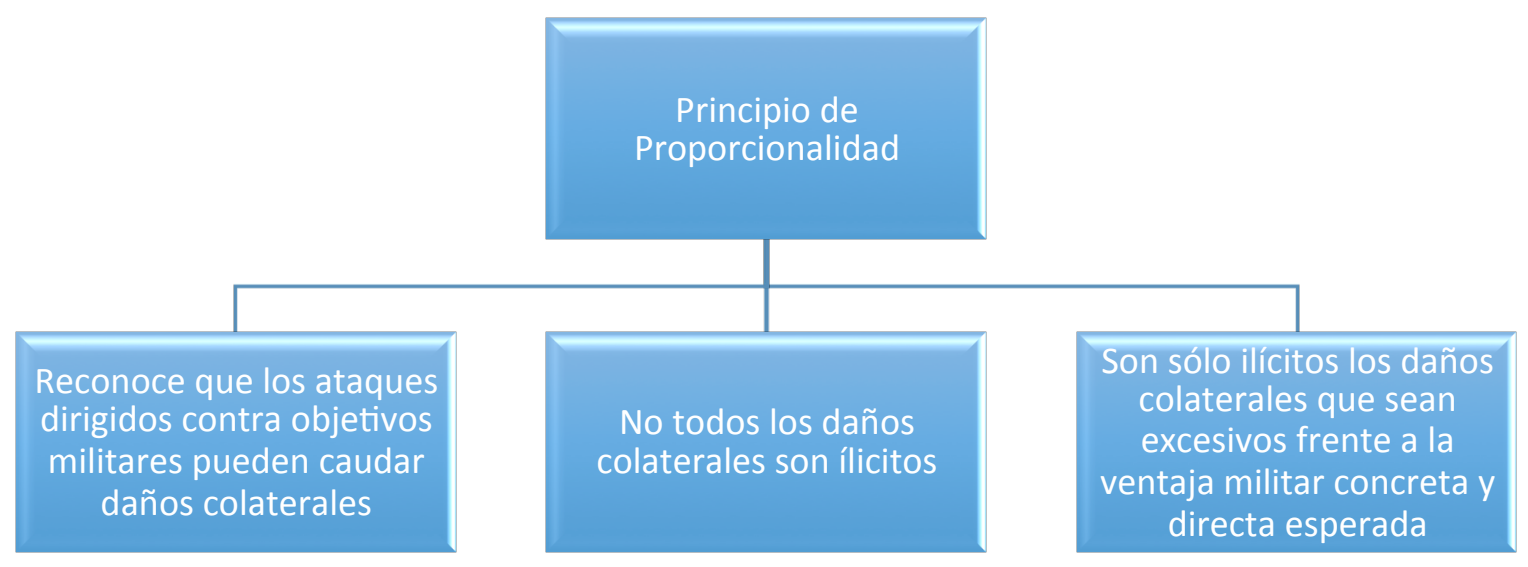

Gráfica 4. Relevancia del principio en el marco de la comprensión digital. (Vicepresidencia, 2010, pág. 221)

Según el diagrama anterior, y la denominación del principio de proporcionalidad surgen dos conceptos que resultan relevantes de cara a la comprensión integral del papel del combatiente en sentido genérico o específico y su obligación de observar esta costumbre de la 
guerra, la doctrina del CICR se refiere a la ventaja militar y daños colaterales, a continuación entonces de manera sucinta se hace una compilación de lo que se debe entender por estos dos conceptos y se verificar su aplicación en los CANI y CAI.

\subsubsection{Ventaja militar concreta y directa}

La ventaja militar, hace alusión a la contribución eficaz que puede tener una acción militar para alcanzar los objetivos de una parte del conflicto (Sentencia C291, 2007), de lo que se trata es de analizar y ponderar la utilidad de atacar un blanco determinado, no simplemente utilizar recursos porque sí, sino pretende todo un proceso específico de cara a verificar el valor y la contribución eficaz que la acción bélica tendrá en la misión u objetivo trazado con la campaña militar (Anaya, 2005).

Como lo señala Ayala, "la ventaja militar se utiliza en el derecho de los conflictos armados cuando se da la definición de objetivo militar, y cuando se estipulan las precauciones que deben tomarse en el ataque a fin de preservar tanto como sea posible a la población civil, a las personas civiles y los bienes de carácter civil” (Ayala, 2007, pág. 111).

Respecto de los ataques que se plantean en el acápite anterior, "estos comprenden los actos de violencia contra el adversario, sean ofensivos o defensivos. Este término se aplica a todo tipo de situaciones, desde el caso de un soldado que dispara un fusil hasta el fuego artillero y la entera gama de acciones individuales o de grupo en el marco de una gran defensa" (Vicepresidencia, 2010, pág. 224)

Comprende la valoración desde la perspectiva operacional del contexto en el cual se desenvolverán los acontecimientos, así por ejemplo si la pretensión es realizar una descarga de armas a través de un bombardeo a un campamento de un GAO, se debe tener en cuenta la proximidad de las viviendas civiles aledañas, en caso tal que la neutralización del blanco represente un cambio radical en el desarrollo de la confrontación armada, podría considerarse su ataque si se toman las precauciones necesarias para minimizar el daño.

Esa valoración debe surgir de la inteligencia adecuada, especialmente por la movilidad que estas organizaciones criminales tienen en sus zonas de influencia, la estrategia de la guerra asimétrica contempla precisamente el movimiento permanente, como una opción para evitar la 
localización y neutralización a través de ataques coordinados por las distintas fuerzas gubernamentales, por ello, la inteligencia de combate es la mejor herramienta para ponderar la ventaja miliar que una acción bélica genera en el teatro de las operaciones (FFMM, 2010).

Algunos parámetros para determinar la ventaja miliar que un ataque podría dar respecto de un objetivo militar, fueron ponderados por el Coronel Piloto del Ejercito del Aire de España, Javier Gisandéz Gómez (Guisández, 2007), graficando de la siguiente forma en el módulo de lucha contra la impunidad, el cual se trae a colación por considerar la pertinencia que tiene en el desarrollo de la presente argumentación:

\begin{tabular}{|c|c|}
\hline Parámetro de valoración & Descripción \\
\hline $\begin{array}{l}\text { Importancia del objetivo militar } \\
\text { para el enemigo }\end{array}$ & $\begin{array}{l}\text { Este parámetro incide positivamente en la valoración de la } \\
\text { ventaja militar, es decir que entre más importante sea, por } \\
\text { razones militares, el objetivo militar para el enemigo } \\
\text { mayor ventaja se esperará del ataque. La importancia del } \\
\text { objetivo militar a atacar se puede deducir de la } \\
\text { información de inteligencia, la ubicación de bien, entre } \\
\text { otros. }\end{array}$ \\
\hline $\begin{array}{l}\text { Importancia del objetivo militar } \\
\text { para el atacante }\end{array}$ & $\begin{array}{l}\text { Su incidencia en el momento de determinar la ventaja militar de } \\
\text { un ataque a un objetivo militar es positiva. La importancia debe } \\
\text { radicar en razones militares y se puede deducir de las } \\
\text { capacidades intrínsecas de objetivo, como potencia de fuego y } \\
\text { su alcance, si trata de armas, la preparación y entrenamiento en } \\
\text { el caso que sea una unidad. }\end{array}$ \\
\hline Capacidad de amortiguamiento & $\begin{array}{l}\text { Es la capacidad del enemigo para minimizar los efectos de los } \\
\text { daños que se han causado con el ataque. Su incidencia en la } \\
\text { valoración de la ventaja militar es negativa, dado que entre } \\
\text { mayor sea la capacidad de amortiguamiento del enemigo menor } \\
\text { valor tiene el objetivo. }\end{array}$ \\
\hline $\begin{array}{l}\text { Reservas existentes de la misma } \\
\text { naturaleza. }\end{array}$ & $\begin{array}{l}\text { Se refiere a la cantidad de elementos iguales de que dispone la } \\
\text { otra parte en el conflicto, a su capacidad para suplir } \\
\text { inmediatamente la ventaja militar prevista en el ataque, por lo } \\
\text { tanto su incidencia es negativa. }\end{array}$ \\
\hline $\begin{array}{l}\text { Dispersión de los elementos del } \\
\text { objetivo }\end{array}$ & $\begin{array}{l}\text { Si el objetivo militar está disperso, lo bienes o personas que } \\
\text { pueden ser objeto de ataque deben considerarse como objetivos } \\
\text { militares distintos. Incide negativamente en la valoración de la } \\
\text { ventaja militar, dado que entre mayor sea la dispersión, mayor } \\
\text { esfuerzo, mayor tiempo, mayor cantidad de armas. }\end{array}$ \\
\hline $\begin{array}{l}\text { Distancia del objetivo desde el } \\
\text { punto inicial }\end{array}$ & $\begin{array}{l}\text { En este parámetro se debe considerar el esfuerzo que debe } \\
\text { invertirse desde el inicio del ataque, durante su realización y } \\
\text { hasta la recuperación. Su incidencia es negativa. }\end{array}$ \\
\hline Facilidad para su identificación & $\begin{array}{l}\text { Tiene una incidencia positiva en el momento de determinar la } \\
\text { ventaja militar, dado que entre más fácil sea identificar un } \\
\text { objetivo militar se disminuye la posibilidad de error. }\end{array}$ \\
\hline
\end{tabular}

(Vicepresidencia, 2010, pág. 227) 


\subsubsection{Daño colateral}

Los daños colaterales son aquellos perjuicios involuntarios que surgen en el desarrollo de una hostilidad como consecuencia de un ataque a un objetivo militar, en la doctrina operacional es considerado como:

(...) perjuicios causados a las personas y bienes de carácter civil, como resultado de un ataque dirigido a un objetivo militar lícito. No serán daños colaterales los generados por un ataque dirigido directamente contra la población civil, sino aquellos que se producen como consecuencia de la acción militar sobre una persona o bien que puede catalogarse como objetivo militar. A la luz del DIH, los daños serán ilícitos solo cuando se rompa el equilibrio exigido por el principio de proporcionalidad.

Cuando el ataque se dirige contra un objetivo militar, este se puede considerar, en principio, lícito, incluso, a pesar de haberse generado daños colaterales o incidentales. Tampoco son daños colaterales los ocurridos a los bienes que puedan considerarse como objetivo militar, a las personas que participan directamente en las hostilidades, y a los bienes que tengan doble uso, es decir, aquellos que son utilizados en tiempos de conflictos armados con fines civiles y también para apoyar el esfuerzo militar de una de las partes (Manual FFMM, 2015, pág. 77).

De lo anterior podemos decir que un daño colateral debe estar ausente de dolo, es decir, si el ataque es dirigido directamente contra la población civil que no participa directamente en las hostilidades, no podrá considerarse como tal, será una grave infracción a las reglas de la guerra, por ello, cualquier vulneración que se realice dentro del proceso de valoración del hecho concreto, deberá tener en cuenta cual era la intención inicial del ataque, la finalidad pretendida con el mismo y la ventaja militar concreta que quería lograrse del hecho atribuible al grupo armado.

Es importante señalar que el Manual de San Remo suscrito el 30 de junio 1994, añade una frase adicional a la formulación de la regla de proporcionalidad. Esa frase establece que "se reconoce que las lesiones incidentales a las personas civiles y el daño colateral a los objetos civiles pueden ocurrir como resultado de un ataque lícito contra combatientes u objetivos militares" (Sentencia C388, 2014).

En ese contexto se hace evidente una pequeña diferenciación entre daño colateral e incidental, al señalar que los daños incidentales son los causados a la vida e integridad de las personas protegidas, mientras que los daños colaterales son los que pueden sufrir los bienes, no obsten en la mayoría de los instrumentos del Derecho Internacional Humanitario se plantea 
una conjunción "o" que los hace equiparables frente a personas y bienes protegidos de las consecuencias de las hostilidades.

En cualquier caso, en el ataque a un objetivo militar como lo señala Burguer (2000): "se deben además tener en cuenta los principios del derecho del conflicto armado que imponen límites tanto a los daños colaterales causados a los civiles que no toman parte en las hostilidades, como a los daños colaterales a los bienes civiles, incluidos los bienes culturales. Los daños colaterales son daños causados involuntariamente a bienes que en sí mismos no son parte de un objetivo militar válido, pero que ocurren incidentalmente al atacar ese objetivo" (Burger, 2000).

Si el ataque se dirige prima facie hacia un objetivo militar, el daño atribuible con la acción será lícito, salvo que se rompa el equilibrio pretendido con el principio de proporcionalidad, es decir, la ponderación entre la ventaja militar obtenida y la necesidad militar, teniendo en cuenta además que en los CANI, están prohibidos los ataques directos contra la población civil o sus bienes, en esta clase de conflictos, los ataques surgen de un proceso de valoración, antes, durante y después de la confrontación armada, la inteligencia militar debe limitar los posibles efectos que puedan surgir del uso de la fuerza y en consecuencia alejar a las personas y los bienes que no participan en las hostilidades.

\subsubsection{Principio de Necesidad Militar}

Según la doctrina especializada, "el principio de necesidad militar es uno de los principios generales de la conducción de las hostilidades. La fuerza militar debe ser necesaria y

proporcionada (Proporcionalidad), y distinguir entre civiles y combatientes, así como entre bienes civiles y objetivos militares. La preocupación fundamental del Derecho Internacional Humanitario es asegurar que se logre un equilibrio entre la necesidad militar y las consideraciones humanitarias" (DFAE, 2014, pág. 40). Toda actividad militar debe justificarse por motivos militares, en consecuencia se prohíben todas aquellas actuaciones que no sean militarmente necesarias (Rogers, 1999).

De conformidad con señalado por (Mejia A, Mejia O, Cote, \& Cardenas, 2009), en el módulo de aplicación de los principios del DIH a los tipos penales consagrados en el Título II 
del Código Penal y al artículo 48 del Código Único Disciplinario, señalan que el principio de necesidad militar cuenta con los siguientes elementos:

- El uso de la fuerza puede y debe ser controlado. Los medios para lograr la victoria no son ilimitados.

- La necesidad militar no permite el uso de la fuerza si este va en contra de lo dispuesto por el DIH. La necesidad militar no puede ser utilizada como excusa para desbordar el marco jurídico del DIH.

- El uso de la fuerza de acuerdo con las reglas del DIH es legítimo si es necesario para lograr, lo más rápido posible, la completa parcial sumisión del enemigo. Por el contrario, el uso de la fuerza que no sea necesario será ilegal, si existen asesinatos crueles o destrucción innecesaria (Mejia A, Mejia O, Cote, \& Cardenas, 2009, pág. 197).

Con ello los ataques contra la población civil, generalmente van en contravía de la necesidad militar, bajo esa premisa el uso de la fuerza debe ser controlado y regulado, controlado en cuanto a su efectos y regulado respecto de los medios empleados para adelantar la confrontación armada, su aplicación está íntimamente relacionada con el principio de distinción y proporcionalidad, bajo el entendido que "(...) solo el grado y el tipo de fuerza que no están prohibidos de otro modo por el derecho de los conflictos armados, que sean necesarios para lograr el objetivo legítimo del conflicto, a saber, la sumisión total o parcial del enemigo en el más breve plazo con un costo mínimo de vidas humanas y recursos” (Melzer, 2010, pág. 79).

Teniendo en cuenta lo contemplado por la doctrina operacional aplicable para las Fuerzas militares colombianas, "este principio se refrenda en el preámbulo de la Declaración de San Petersburgo de 1868, donde se estipula que la única finalidad legítima que los Estados deben proponerse durante la guerra es el debilitamiento de las fuerzas militares del enemigo y que "a este fin, basta con poner fuera de combate al mayor número posible de hombres" fuerza es legítimo, en la medida que no persiga un fin ilegitimo en sí mismo, en materia de DIH, solo son lícitos aquellos actos que pretendan la debilitación del enemigo, la necesidad militar en su sentido más estricto, si en el derecho positivo se admite por excepción hecha en nombre de esa necesidad, que se suspenda una prohibición o una limitación determinada en el recurso a la violencia de guerra (Ayala , 2007, pág. 88).

Según la doctrina especializada: 
Expresiones tales como necesidad de las operaciones militares, exigencias, motivos o razones militares, razones de guerra, razones de seguridad, etc, deben entenderse como sinónimos de la locación necesidad militar. Dado que la necesidad militar se opone generalmente a las exigencias humanitarias, el esfuerzo esencial del derecho humanitario consiste en encontrar un punto de equilibrio entre las primeras y las segundas (Ayala , 2007, pág. 88).

El siguiente cuadro construido por (Mejia A, Mejia O, Cote, \& Cardenas, 2009, pág. 198) permite resumir las reglas para la aplicación de este principio en el contexto del análisis del objetivo militar:

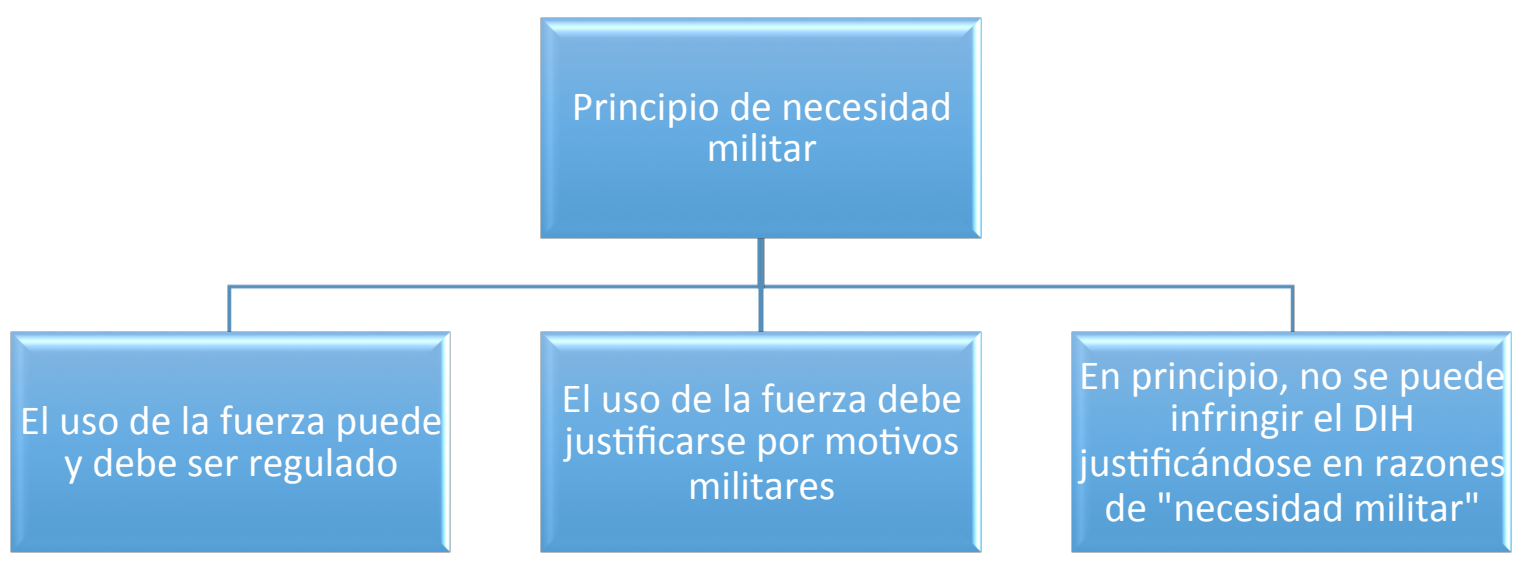

Gráfica 5. Análisis del objetivo militar. (Vicepresidencia, 2010, pág. 198)

Teniendo en cuenta lo anterior, la necesidad militar constituye la justificación desde la perspectiva del derecho a la guerra, para atacar objetivos militares, contrarrestar el accionar de los GAO que delinquen en algunas zonas donde tienen injerencia, y preparan las operaciones militares, logrando disminuir a un mínimo razonable las consecuencias de la confrontación armada y las afectaciones que pueden sufrir con el accionar bélico los civiles que no participan en las hostilidades o incluso los combatientes que por los devenires del combate han dejado de hacerlo.

En algunos manuales de derecho operacional en el derecho comparado, se hace uso del vocablo "necesario" y estrictamente indispensable", como una categorización de la prioridad en la selección de bancos que contribuyan de manera eficaz al desarrollo de las operaciones en 
le campo de combate, algunos reglamentos sobre el uso de la fuerza lo desarrollan de la siguiente manera:

Colombia: Manual de derecho operacional para las fuerzas militares 3-41 señala: "Principio de necesidad militar: permite emplear todos los recursos, métodos y medios permitidos e indispensables para cumplir la misión, causando el menor costo en personas, bienes y recursos propios. Bajo el entendido que, "[...] solo el grado y el tipo de fuerza que no están prohibidos de otro modo por el derecho de los conflictos armados, que sean necesarios para lograr el objetivo legítimo del conflicto, a saber, la sumisión total o parcial del enemigo en el más breve plazo con un costo mínimo de vidas humanas y recursos" (Manual FFMM, 2015, pág. 28).

Ecuador: Manual de derecho en las Operaciones militares: "3.1.2 Principio de necesidad militar Toda actividad de combate debe justificarse por motivos militares; están prohibidas las actividades que no sean militarmente necesarias. Está prohibido atacar a personas civiles o a quienes estén fuera de combate, porque con ello no se obtiene ventaja militar alguna. No se puede invocar como excusa la necesidad militar para invalidar el derecho de los conflictos armados" (Manual Operacional Ecuador, 2014, pág. 120).

Perú: Manual para las fuerzas Armadas: "Necesidad Militar: Es la toma de medidas necesarias para conseguir las metas de la guerra. Constituye la justificación de todo recurso a la violencia, dentro de los límites establecidos por el principio general de la proporcionalidad. En su sentido estricto, indica una necesidad estipulada en normas de derecho internacional. El Principio de Necesidad Militar establece que en todo conflicto armado el uso de la fuerza debe corresponder a la ventaja militar que pretende obtenerse. Las necesidades militares no excusan una conducta inhumana, ni alguna actividad que esté prohibida por el Derecho Internacional Humanitario" (Manual Fuerzas Armadas Perú, 2010, pág. 224).

Nótese que cada uno de los vocablos son empleados indistintamente en las regulaciones en cita, partiendo que la necesidad militar permite el uso de la fuerza que sea "necesario" en relación con el objetivo militar seleccionado, utilizado para tal fin los medios y métodos "estrictamente indispensables" para neutralizar el blanco, procurando causar los daños mínimos en los bienes y recursos de la población civil (proporcionalidad) (Ramelli, 1999). 


\subsection{Modos y métodos asimétricos en el contexto del conflicto armado colombiano}

Según la doctrina especializada del CICR, "el derecho internacional limita los métodos y los medios de guerra. Esas restricciones se aplican al tipo de armas utilizadas, a la manera en que se las emplea y a la conducta general de todos los que participan en el conflicto armado. El principio de distinción establece que las partes en un conflicto armado deben distinguir en todo momento entre combatientes y objetivos militares, por un lado, y personas civiles y bienes de carácter civil, por el otro, y atacar sólo a los objetivos legítimos" (CICR, 2011) .

No obstante la anterior prohibición, el conflicto armado colombiano se ha degradado en cuanto a métodos y formas de combinar la confrontación armada, la inferioridad manifiesta de los GAO, ha derivado en la utilización de estrategias prohibidas por el $\mathrm{DIH}$, la utilización de menores de edad para la lucha, artefactos explosivos letales sembrados en los caminos veredales, campos minados en las diferentes labranzas de los campos, son solo algunas de las formas como estos grupos han pretendido obtener sus fines, la dificultad en el control de sus efectos, convierte a los civiles en mártires potenciales y con ello, víctimas de la guerra que hoy por hoy se suman por millones.

En ese contexto, la implicación asimétrica de los modos y métodos para realizar la confrontación armada, implica la utilización de armas no convencionales, la mayoría de ellas de fabricación artesanal, propias de la guerra de guerrillas, violatorias de normas de derechos humanos, usadas solo para escalar el conflicto y con ello obtener réditos políticos de cara a una probable negociación (Chornet, 2006, pág. 273).

Aquella ha sido la constante, la dinámica de la guerra que ha marcado la historia de varias generaciones, colombianos de todos los orígenes y concepciones ideológicas han resultado afectados por sus efectos, la intimidación, el terror, el desplazamiento y la barbarie, son la consecuencias mediatas del uso indiscriminado de esta clase de armas, la conformación de todas las formas de lucha, al incluir el terrorismo y la desolación, ha derivado en la muerte de miles de personas.

Partiendo de estas aseveraciones y valiéndose como fuente primaria de información de los medios de comunicación, a continuación se analizarían de manera general tres modos y 
métodos de realizar la confrontación armada por parte de los GAO; la utilización de menores en el desarrollo de las hostilidades, la utilización de artefactos explosivos improvisados en todas sus manifestaciones y el secuestro de personas, como herramientas asimétricas de lucha anti-estatal.

\subsubsection{Menores de edad utilizados por los GAO en la guerra asimétrica}

Colombia es un Estado social y democrático de derecho, dicha denominación visible en el preámbulo de su Constitución, obliga al gobierno nacional a implementar estrategias orientadas a lograr el pleno goce y disfrute de las garantías para todos los habitantes de la nación, los derechos fundamentales inalienables se convierten en la principal garantía que nace con el ser humano, objeto de protección sin distingo por razones de sexo, raza, origen social, color de piel o ideología.

En dicha retorica utópica, los menores de edad tienen una protección reforzada por el artículo 44 Constitucional, al punto que sus derechos prevalecen por encima del de los demás, aquello fue reconocido por la Corte Constitucional al señalar:

Los derechos fundamentales de los niños, niñas y adolescentes gozan de una especial protección tanto en el ámbito internacional como en nuestro Estado Social de Derecho. Ello, dada la situación de indefensión, vulnerabilidad y debilidad de esta población y la necesidad de garantizar un desarrollo armónico e integral de la misma. Los niños, en virtud de su falta de madurez física y mental -que les hace especialmente vulnerables e indefensos frente a todo tipo de riesgos-, necesitan protección y cuidados especiales, tanto en términos materiales, psicológicos y afectivos, como en términos jurídicos, para garantizar su desarrollo armónico e integral y proveer las condiciones que necesitan para convertirse en miembros autónomos de la sociedad. Atendiendo esta norma básica contenida en el preámbulo de la Convención sobre los Derechos del Niño y en la Declaración de las Naciones Unidas sobre los Derechos del Niño, el artículo 13 de la Constitución Política de Colombia, exige la obligación de prodigar una especial protección a aquellos grupos sociales cuya debilidad sea manifiesta, destacándose entre estos grupos la especial protección de los niños, la cual es prevalente inclusive en relación con los demás grupos sociales (Sentencia T260, 2012).

Dicha configuración jurisprudencial exige del Estado el mayor esfuerzo por mantenerlos alejados de los peligros propios de una sociedad en decadencia, algo muy difícil de conseguir especialmente en las zonas apartadas del país, donde la autoridad no la ejerce el ente gubernamental, la autoridad proviene del GAO que tenga mayor influencia y ostente el control 
territorial necesario para someter la voluntad de la población que habita la región (Bondia, 2009, pág. 152).

En estas poblaciones apartadas, incluso en los barrios circundantes de las principales ciudades, se ha presentado la oprobiosa e ilegal práctica del reclutamiento de menores (Santacruz, 2011), desde siempre ha sido una estrategia seguida por las FARC, el ELN, las AUC, y demás grupos armados que históricamente han delinquido en los diferentes departamentos del país, arrebatan de sus familias a los menores de edad para engrosar las filas de sus estructuras y ser utilizados en labores disimiles, contribuyendo de esta manera con el objetivo de la organización.

Esta práctica constituye una flagrante infracción al DIH, y por ende un crimen de guerra sancionado por el Estatuto de la CPI, el cual contempla en su articulado dicha prohibición al siguiente tenor:

2. A los efectos del presente Estatuto, se entiende por "crímenes de guerra": a) Infracciones graves de los Convenios de Ginebra de 12 de agosto de 1949, a saber, cualquiera de los siguientes actos contra personas o bienes protegidos por las disposiciones del Convenio de Ginebra pertinente:

xxvi) Reclutar o alistar a niños menores de 15 años en las fuerzas armadas nacionales o utilizarlos para participar directamente en las hostilidades; (CPI, 2016)

Al igual está contemplado en la legislación interna como delito, una grave infracción al DIH de conformidad con lo previsto en el artículo 62 de la ley 599 de 2000, con una diferencia frente a lo dispuesto en el Estatuto de Roma y es que aquí se sanciona el reclutamiento de los menores a partir de los 18 años de edad, contrario de lo que sucede en el estatuto de la CPI que prevé la sanción a partir de los 15 años, esta norma que estipula:

Artículo 162. Reclutamiento Ilícito. El que, con ocasión y en desarrollo de conflicto armado, reclute menores de dieciocho (18) años o los obligue a participar directa o indirectamente en las hostilidades o en acciones armadas, incurrirá en prisión de noventa y seis (96) a ciento ochenta (180) meses y multa de ochocientos (800) a mil quinientos (1500) salarios mínimos legales mensuales vigentes (Senado, 2000).

Diferencia resaltada también por la Corte Constitucional, que sea por demás advertir la encontró ajustada a los preceptos constitucionales internos al señalar: 
Los niños y las niñas en los conflictos armados se encuentran protegidos por el DIH desde una doble perspectiva: (i) en su calidad de civiles afectados por las hostilidades y (ii) como sujetos vinculados a ellas en conflictos armados internacionales y no internacionales, de acuerdo con los artículo 77 del Protocolo I y al artículo $4^{\circ}$ del Protocolo II adicionales a los Convenios de Ginebra, respectivamente, siendo el reclutamiento y la participación de menores de 15 años de edad en los conflictos armados, una conducta prohibida por el DIH. Los Estados Parte se comprometen a tomar todas las medidas legislativas necesarias para sancionar a las personas culpables de infracciones graves contra esos Convenios y se obligan a enjuiciar a las personas sospechosas de haber cometido infracciones graves contra esos tratados o a transferirlos a otro Estado para que los enjuicie, siendo de resaltar que la distinción que las normas del DIH hacen entre niños y adolescentes en lo que respecta al marco de protección particular a los menores de 15 años reclutados o utilizados en el conflicto, no desvirtuaba la prevalencia de los derechos de los menores de 18 años en el ordenamiento interno, dado que el esquema de protección constitucional colombiano cobija a todos los individuos que se encuentran en esa franja cronológica (Sentencia C240, 2009). (Subrayado fuera de texto)

De lo anterior se puede resaltar la prohibición existente tanto en las normas del DIH, como en las normas del derecho penal positivo (Estatuto de Roma y Ley 599 de 2000), pese a ello, esta práctica ha sido recurrente en la realidad nacional, hasta hace muy poco las FARC continuaban reclutando menores de edad, incluso después de firmar el proceso de paz de la Habana, aún continúan en sus filas centenares de niños y niñas que fueron reclutados a la fuerza en los campos colombianos.

Esto sin duda es una flagrante violación a las normas tanto del DIH como del DIDH, ya que los niños deben estar alejados del conflicto, su protección entonces es bipartita, por su implícito papel como población civil y por ser considerados los seres más vulnerables en el trafico jurídico de los estados, la utilización entonces de ellos en la guerra, además de ser como ya se señaló una grave infracción al DIH, atenta contra el futuro del Estado ya que en ellos descansa la esperanza de un mundo mejor.

Estos menores, pese a las prohibiciones ya descritas, han hecho parte de las estructura de los grupos armados, un estudio presentado por la UNICEF y la Defensoría del Pueblo, destacan las razones por las cuales se dio el ingreso de estos seres humanos a los GAO, además refieren la motivación para su ingreso, al respecto en dicho informe se destaca:

Frente a la pregunta de: ¿Cómo ingresó al grupo armado? algunos testimonios fueron:

"Desde pequeño, para uno un tiroteo es normal, cuando matan a alguien es común y corriente", joven de 16 años. 
"Mi padre vino por mí y me llevó a la fuerza, yo vivía con mi mamá y mi padrastro, él los asesinó y me obligó a ir con él”, joven de 16 años.

"Un miliciano fue a hablar con mi mamá y ella me empacó la ropa y me tocó irme con ellos", joven reclutado a los 14 años.

"Yo fui a conocer, pero a mí no me gustó, pero ya no me dejaron salir", joven de 15 años.

"Me dijeron que me fuera con ellos o sino me mataban porque yo era novia de un policía", joven de 15 años.

"Yo me fui, pero engañada porque me prometieron plata y estudio", joven de 16 años.

Frente a la pregunta de: ¿Cuál fue la motivación para ingresar al grupo armado?, algunos testimonios fueron:

"Estar en la guerrilla es bonito, uno aprende disciplina y uno se forma", joven de 16 años.

"Mi papá es guerrillero", joven de 15 años.

"A mí me gustaba la guerrilla porque yo veía que ellos eran admirados por la gente", joven de 16 años.

"Yo estaba aburrida por el maltrato que me daban en mi casa", joven de 16 años.

"Pensé que la vida con ellos era bonita, y yo tenía problemas con mi mamá y en la escuela", joven de 17 años.

"Tuve problemas con los paracos, así que para mí era mejor entrar a la guerrilla", joven de 16 años. "Sentía que mi familia y amigos se estaban alejando de mí, me sentía solo", joven de 16 años. (UNICEF, 2012)

Razones disimiles pero todas unidas por un mismo hilo conductor, el engaño, la manipulación, la obligación y el maltrato, pueden resumir las razones por las cuales estas personas ingresan a estos grupos armados, su papel en él, generalmente está asociado al cumplimiento de tareas en el campo de combate, muchas de las cuales revisten dificultad a la hora de interpretar la posibilidad de ataque, lo cual es aprovechado por los cabecillas de estas estructuras, que encuentran en los menores de edad herramientas útiles para la perpetración de sus actos terroristas (Santacruz, 2011).

\section{Como fuera señalado por Verdadabierta.com:}

El 2013 cerró con la publicación de un informe devastador: la Organización Internacional para la Migraciones, OIM, Unicef y el Instituto Colombiano de Bienestar Familiar (ICBF), entrevistaron a más de 1.600 menores de entre 8 y 18 años, víctimas de la violencia, de los cuales 338 habían sido reclutados por los grupos armados, en su mayoría por las Farc, quienes contaban entre otras cosas que habían tenido que fusilar a compañeros de su edad durante los Consejos de Guerra (Verdad Abierta, 2015)

Lo cual hace pensar en grado de degradación que ha tenido la guerra, la vinculación temprana de los menores de edad, la obligación de cometer crímenes en nombre de la estructura, significa un crimen atroz, una forma de afectar su presente pero sobre todo su 
futuro, un aparte del relato de un niño que fue obligado a ingresar a las FARC cuando tenía 12, presentado por el Periódico el País de la Ciudad de Cali, contribuye a resaltar la problemática planteada:

Nos enseñan que el entrenamiento de un guerrero debe ser fuerte y extenuante para que la guerra sea un descanso y eso es lo que importa. Nos decían que nos cuidáramos de los bombardeos, porque sabíamos que por tierra siempre íbamos a ganar nosotros. Las normas en la guerrilla son claras y no cumplirlas es condenarse a muerte, es un suicidio.

(...)

El viejito era buena gente. Tenía una tiendita cerca del pueblo. Muchas veces nos regaló pan y gaseosa, lo tenían amenazado, le pedían 'vacuna'. Mi obligación era matarlo. ¿Por qué? No sé, de pronto para demostrar 'garra' y lo hice, lo maté".

(...)

Me arrepiento de haberlo matado a él y a las otras dos mujeres que tuve que 'dar de baja' por traición. Fue por órdenes del comandante de turno. Las dos mujeres también eran guerrilleras, según el comandante ellas habían traicionado los ideales de las Farc. Nunca me explicó por qué teníamos que asesinarlas, supongo que no me lo dijo porque yo solo era un 'chinito' en esos momentos. Creo que ambas quedaron en embarazo y por eso fue. Las matamos y descuartizamos, es lo único que sé (Montoya, 2012).

Nótese como estos menores son utilizados para perpetrar crimen atroces, en muchos casos sin saber el motivo, su temprana edad, su personalidad, su forma de concebir el mundo es vilmente manipulada, los niños son fácilmente influenciables, acatan las ordenes sin cuestionar las razones, se pueden camuflar muy fácil en la población civil, son algunas de los motivos por las cuales estas estructuras tienen en sus filas a niños, niñas y adolescentes (Santacruz, 2011).

Lo menores en esas circunstancias son utilizados por las estructuras de los diferentes GAO, en tareas de inteligencia, búsqueda de información, sembrado de minas, activación de campos preparados, tareas administrativas y logísticas en las zonas campamentarias, ajusticiamiento a informantes o infiltrados y lucha directa contra las fuerzas regulares del Estado.

Todas las prácticas proscritas por el DIH, pero realizadas de manera recurrente, los menores de edad son utilizados en la guerra como una estrategia que representa ventaja militar en un conflicto asimétrico, la muerte de un niño que se presenta en combate es atribuible al grupo armado que lo utilizó en sus filas para esa actividad (Ayala , 2007), pero que difícil es sustentar su aparición en un campo de combate cuando no se le encuentran armas, allí, la 
estrategia de combinación de todas las formas de lucha se realza, ya que el menor que muere puede ser presentado como un civil y con ello una personas internacionalmente protegida, es decir la carga de responsabilidad se invierte y ello lesiona la moral del soldado colombiano, que consideró cumplir a cabalidad con su función, pero resulta injustamente judicializado por la dificultad que reviste sustentar el resultado producto del desarrollo de la confrontación armada.

\subsubsection{Artefactos explosivos improvisados herramienta asimétrica de guerra}

Los artefactos explosivos improvisados (en adelante AEI), han sido utilizados como una estrategia dentro del conflicto asimétrico para hacer la guerra, de alguna manera en algunas zonas del país, han logrado equiparar las cargas y conseguir más víctimas en el grupo contendor, que las producidas en los combates y las confrontaciones directas, su difícil detección, su fácil camuflaje en las áreas veredales y sus bajos costos de operación, han logrado que salgan de combate muchos soldados y policías en todo el territorio nacional.

Las minas antipersonales son una de ellas, según la ONG "Galeón Sin minas Colombia”, estos artefactos son:

(...) pequeños explosivos que pueden estar en cualquier parte. A diferencia de otras armas, para cuya mayoría se precisa que alguien apunte y dispare, las minas terrestres antipersonal son accionadas por las "víctimas". Es decir, están concebidas para explosionar cuando una persona tropiece con ellas o las manipule. Las minas antipersonal no Hacen "distinción" entre soldados y personas civiles. Matan o mutilan a un niño que juega al fútbol con la misma facilidad que a un soldado que patrulla. El propósito de estas armas es matar o, más a menudo, discapacitar de por vida a las víctimas. Están específicamente hechas para destrozar miembros y vidas sin posibilidad de reparación. Pueden estar disfrazadas o escondidas en tarros, juguetes, cajas, ollas o en cualquier cosa que parece inofensiva como un zapato, una cajetilla de cigarrillos o entre una bolsa. Las minas antipersonal tienen en su interior puntillas, balines, pedazos de lata, vidrios, combinados con excrementos, con ácidos o venenos para infectar o envenenar a las víctimas. Tienen diferentes formas, colores y tamaños, pueden estar fabricadas con madera, hierro, metal o plástico (GALEON.COM, 2016).

Por ello, diariamente los medios de opinión incluyen lamentables noticias en las cuales se registran las víctimas de estos artefactos explosivos, los periódicos de todo el país han dado cuenta de manera reiterada de cómo la población civil y miembros de la fuerza pública constantemente están resultando afectados con estos artefactos, noticia como por ejemplo la 
muerte de un niño de 6 años presentada en la área rural de Algeciras - Huila, quien pisó una mina cuando jugaba, son un ejemplo de lo aquí señalado:

Cuando el balón rodó varios metros por un platanal, uno de ellos corrió a buscarlo con tan mala suerte que pisó, al parecer, una mina antipersona o cualquier otro explosivo", aseguró el coronel Pinzón, y agregó que "la carga le amputó una mano y las esquirlas le ocasionaron heridas de gravedad en el abdomen (El tiempo, 2016).

Noticia que destaca la muerte de una víctima inocente del conflicto, en una zona de influencia de las FARC. También en el Cauca se han presentado esta clase de afectaciones, una de ellas cobro la vida de una niña, así lo registraron los medios en su momento:

Conmoción y tristeza profunda embarga a los habitantes de la vereda Aguaclara, en el sector del Nevado, parte alta del municipio de Buenos Aires, norte del Cauca, por la muerte de una niña de ocho años víctima de mina antipersona. Otros tres menores resultaron heridos, que inicialmente fueron atendidos en el puesto de salud del corregimiento de Timba y de ahí fueron remitidos a una clínica de Popayán. Según el reporte médico, presentan lesiones leves, pero con afectaciones psicológicas (Caracol TV, 2015) .

No solamente lo niños resultan afectados, también los adultos y los miembros de la fuerza pública, los soldados y policías en todo el territorio nacional que arriesgan su vida también son víctimas de estos artefactos explosivos, al respecto los medios difundieron esta noticia:

El soldado Wilson de Jesús Martínez, de 37 años, que participaba en el primer operativo del desminado humanitario con las Farc en la vereda El Orejón de Briceño (Antioquia) murió al pisar accidentalmente una mina antipersonal. En el hecho también resultaron heridos dos desminadores, quienes recibieron atención inmediata. Ellos sufrieron afectación en sus oídos como consecuencia de la explosión y ya se encuentran fuera de peligro (Noticias RCN, 2015). La cual es solo una muestra de toda la afectación que trae consigo esta arma utilizada como estrategia de guerra, en un informe presentado por la ONG Colombia sin minas, al realizar un análisis del número de víctimas que se presentaron como consecuencias de la utilización de estos AEI, en la población civil en el periodo de tiempo donde el conflicto colombiano fue más cruento, reporta el siguiente cuadro que corresponde al periodo entre el 1990 hasta 2007:

Algunas estadísticas que surgen de la información compilada por distintas ONGs, contribuyen a dimensionar la problemática evidenciada en las diversas regiones del país, sifras que pos si sola dan cuenta de una realidad que enmarca de luto y dolor el campo colombiano, las cifras se presentan en el siguiente diagrama: 


\begin{tabular}{|c|c|c|c|c|c|c|c|}
\hline Año & Mujer & Niña & Hombre & Niño & $\begin{array}{l}\text { Mayor de } 18 \\
\text { años sin sexo } \\
\text { conocido }\end{array}$ & $\begin{array}{c}\text { Menor de } 18 \\
\text { años sin sexo } \\
\text { conocido }\end{array}$ & Total \\
\hline 1990 & & 1 & 20 & & & & 21 \\
\hline 1991 & & 2 & 57 & 5 & & & 64 \\
\hline 1992 & 5 & 5 & 123 & 11 & 3 & 1 & 148 \\
\hline 1993 & 2 & 1 & 65 & 12 & & & 80 \\
\hline 1994 & 1 & 1 & 71 & 9 & & & 82 \\
\hline 1995 & 11 & 6 & 106 & 7 & & & 130 \\
\hline 1996 & 7 & 4 & 91 & 7 & 7 & & 116 \\
\hline 1997 & 15 & 1 & 55 & 19 & & & 90 \\
\hline 1998 & 4 & 3 & 38 & 9 & & 1 & 55 \\
\hline 1999 & 4 & 2 & 34 & 11 & 1 & & 52 \\
\hline 2000 & 6 & 1 & 107 & 14 & & & 128 \\
\hline 2001 & 15 & 11 & 227 & 33 & & 1 & 287 \\
\hline 2002 & 26 & 23 & 489 & 82 & 2 & 2 & 624 \\
\hline 2003 & 22 & 12 & 640 & 48 & 4 & 2 & 728 \\
\hline 2004 & 22 & 10 & 781 & 50 & 5 & 1 & 869 \\
\hline 2005 & 23 & 30 & 968 & 71 & 9 & 3 & 1104 \\
\hline 2006 & 22 & 12 & 1010 & 54 & 6 & & 1104 \\
\hline 2007 & & & 58 & 4 & & & 62 \\
\hline Total & 185 & 125 & 4940 & 446 & 37 & 11 & 5744 \\
\hline
\end{tabular}

\section{Gráfica 6. Estadística. (GALEON.COM, 2016)}

Dicha estadística presenta un incremento significativo que ubica a Colombia como uno de los países con mayor número de afectados, según la ONU, cada día caen 10 personas como víctimas de estos AEI, al respecto se indicó:

Por años, Colombia ha estado entre los países con más víctimas por minas antipersonal y en el 2013 ocupó el primer lugar, con un promedio de 10 personas, entre heridos y muertos, afectadas por estos artefactos explosivos, según el director de programas del Servicio de Acción de Minas de la ONU, Paul Heslop (Semana, 2014).

Lo cual hace evidente la dinámica de la guerra, y ubica a los GAO, especialmente las FARC como el principal grupo armado que utiliza este tipo de prácticas lesivas, contrarias a la Convención de Ottawa, en donde claramente se señala la razón por la cual se deben prohibir este tipo de estrategias para adelantar la confrontación armada:

Las minas antipersonal no pueden distinguir entre soldados y personas civiles y suelen matar o mutilar gravemente. Al ser relativamente baratas, pequeñas y de fácil manejo, han proliferado por decenas de millones, causando indecibles sufrimientos $y$ devastando social y económicamente a docenas de países en todo el mundo. Dado que resulta mucho más fácil colocarlas que retirarlas, ha sido difícil o imposible utilizar esta arma de conformidad con las normas del derecho internacional humanitario en la mayoría de los conflictos en que se ha empleado (CICR, 1997). 
Aspecto que permite entender la problemática planteada y evidenciar la dimensión de la afectación, es importante además tener en cuenta que en muchos casos los GAO utilizan menores de edad, milicianos, incluso personas civiles para activar, sembrar o construir este tipo de artefactos explosivos, la grave afectación que ello trae para la salud e integridad, representa una ventaja militar para el grupo armado que la utiliza. En ese contexto, las normas del DIH permiten su neutralización, situación que hace evidente la misma problemática planteada en el numeral anterior, como sustentar una muerte de una persona que está sembrando la mina, como justificar ante el operador judicial su grado de participación en las hostilidades (Acevedo, 2016, pág. 217).

Aquello sin duda constituye un reto para los intervinientes del proceso penal, su papel contribuye de manera eficaz a alcanzar los objetivos de la organización que representan, allí el umbral de daño, el nexo causal y de beligerancia saltan a la vista, si asume una función permanente dentro de la estructura, si su contribución siempre es la de construir, manipular y sembrar minas, se podría concluir que desarrolla una función continua de combate y en esa medida, estaríamos frente a un miembro de grupo armado (combatiente en sentido genérico).

Si su papel es eminentemente transitorio, pierde su protección de la que gozan los civiles mientras dure su participación, las característica de la actuación configurar los requisitos del CICR, frente a la participación directa en las hostilidades (Melzer, 2010).

Además de las minas, los cilindros bomba y los "tatucos", resultan también ser AEI utilizados por las estructuras de los GAO para adelantar las acciones en diferentes zonas de influencia, son armas no convenciones que en muchos casos están llenan de metralla para potenciar sus efectos y han sido utilizados generalmente para atacar a las instalaciones militares o de policía y para las tomas en las poblaciones.
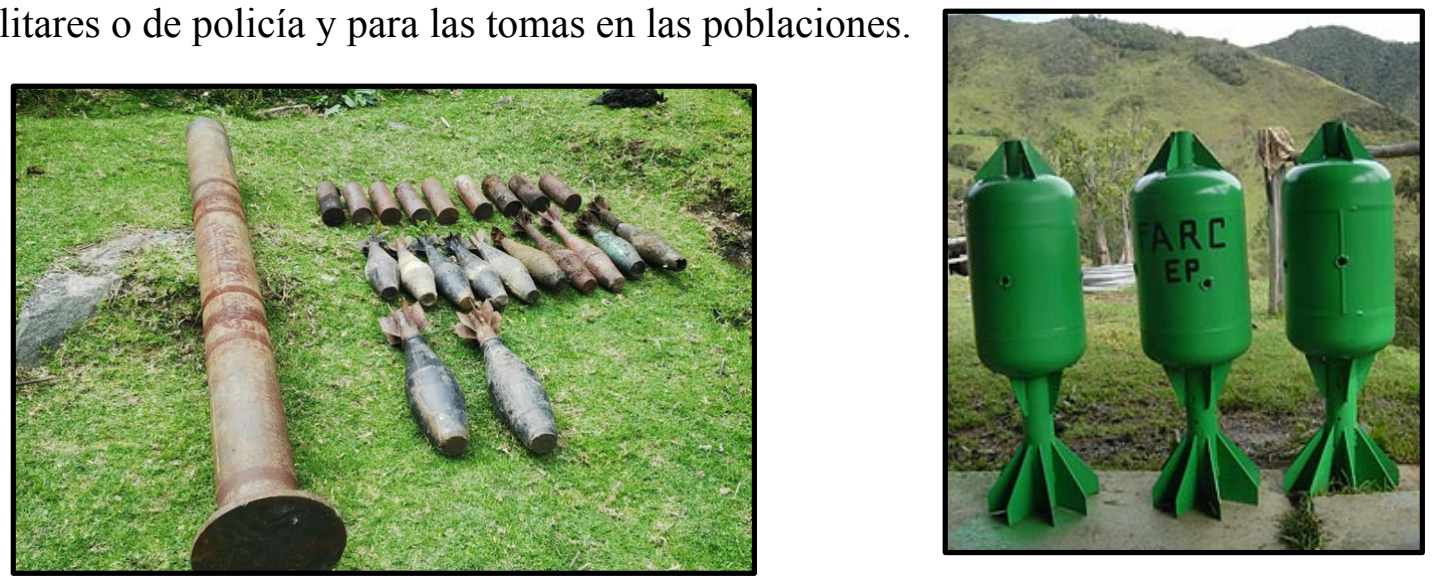
(Imagenes tomadas de El pais.com, 2008)

Estas armas no convencionales, son utilizadas con frecuencia por estas estructuras en sus zonas de influencia, presentan alto poder destructivo y por su fabricación artesanal, no tienen la posibilidad de control respecto del impacto en el objetivo, en múltiples ocasiones artefactos de fabricación artesanal, son lanzados contra estaciones de policía o bases militares, pero no alcanzan su objetivo, llegan directamente a las viviendas aledañas, ello constituye una grave infracción al DIH, especialmente por los daños directos que se generan en la vida y bienes de las personas protegidas.

\subsubsection{El secuestro estrategia asimetría de financiación}

Al igual que la utilización de menores de edad para el desarrollo de las hostilidades y el empleo de artefactos explosivos de fabricación artesanal como armas de guerra, los grupos armados especialmente las FARC y el ELN, desde sus orígenes han utilizado la oprobiosa práctica del secuestro como estrategia de financiación y lucha.

Miles de colombianos han sido víctimas de esta conducta catalogada como una violación a los derechos humanos, en nada equiparable con la toma de rehenes y mucho menos a la toma de prisioneros de guerra, dialéctica que ha sido la constante muchas veces por los grupos armados cuando se les pregunta por esa razón de sus actuaciones.

La ONU, contextualiza su diferenciación al rechazar estas prácticas cada vez más recurrentes en el mundo, precisamente en la Resolución 638 del 31 de julio de 1989, aprobada por unanimidad, sobre "La cuestión de la toma de rehenes y el secuestro" señaló:

(...) la toma de rehenes y los secuestros son delitos que preocupan profundamente a todos los Estados y constituyen serias violaciones del derecho humanitario internacional, con graves consecuencias adversas para los derechos humanos de las víctimas y sus familias y para la promoción de las relaciones de amistad y la cooperación entre los Estados", posteriormente "condena inequívocamente todos los actos de toma de rehenes y de secuestro", y "exige que se ponga en libertad inmediatamente y en condiciones de seguridad a todos los rehenes y personas secuestradas, independientemente del lugar en que se encuentren detenidos y de quien los tenga en su poder", exhortando luego "a todos los Estados a que utilicen su influencia política de conformidad con la Carta de las Naciones Unidas y los principios del derecho internacional a fin de lograr la liberación en condiciones de seguridad de todos los rehenes y personas secuestradas e impedir que se cometan actos de toma de rehenes y de secuestro (Sentencia C291, 2007). 
Recogiendo dicha posición y por supuesto preocupación, la Corte Suprema ha señalado y resaltado en alguna de sus decisiones los elementos constitutivos de una y otra conducta, lo cual ubica el problema en un caracterización semántica, utilizada desde la perspectiva política para minimizar los efectos de lo que en realidad estas prácticas conllevan, la privación efectiva de la libertad de una persona, en dicha decisión se dispuso:

Recordemos que la conducta punible de secuestro extorsivo contiene verbos rectores alternativos, que en este evento serían arrebatar, sustraer, retener u ocultar a una persona con el propósito de exigir por su libertad un provecho o cualquier utilidad o para que se haga u omita algo.

Así, en nada altera para la suerte del procesado que el verbo ejecutado en su conducta hubiese sido ocultar o retener, toda vez que siendo atribuido cualquiera de ellos en nada altera su compromiso penal frente a los hechos (Sentencia Casacion, 2006).

De lo que se trata, sin contar con la semántica es de una privación efectiva de la libertad, una conducta que en los CANI, debe ser sancionada por la legislación interna, así por ejemplo los soldados que estuvieron durante muchos años secuestrados por las FARC después de varias tomas realizadas por esta organización subversiva en diferentes regiones del país, fueron secuestrados, obviamente no prisioneros de guerra, y por ello sus captores deben responder por esa conducta, recordemos que estas organizaciones al tenor de los establecido en el artículo 3 común no tienen las mismas prerrogativas que tiene los combatientes en sentido especifico en los CAI, por ello su responsabilidad debe ser judicializada de conformidad con los artículos 168 y siguientes de la ley penal (Amnistía Internacional, 2008).

Esta práctica afecta a la familia, los procesos personales se aplazan todo gira en torno a la persona que falta, es una marca que difícilmente se borra de la vida de las personas retenidas, privadas de su libertad y de sus familias, ello fue resaltado por el Centro de Memoria Histórica en un estudio según el cual durante las décadas del conflictos más de 207 mil víctimas directas ha generado esta conducta punible, al respecto se señaló:

Afecta al secuestrado y se extiende a otras redes sociales, convirtiéndose en un fenómeno colectivo. Abordarlo desde la postura de las familias implica comprender que, cuando un miembro es secuestrado, toda la atención y los esfuerzos se encaminan a conseguir su liberación. Esto a veces conlleva la desatención de otros miembros del grupo familiar. Las familias están sometidas de forma constante a factores estresantes como la ausencia de pruebas de supervivencia, la incertidumbre sobre la situación real del secuestrado o amenazas para impedir que alerten a las autoridades, además de la sensación de responsabilidad sobre la vida del ausente. Tal estrés deriva en síntomas como la irritabilidad, la impotencia, la rabia, la desesperanza, la preocupación y la angustia. Como consecuencia, se puede generar 
desestabilización de las dinámicas familiares y surgen opiniones divididas frente a la manera de afrontar la situación (Centro Nacional de Memoria Histórica, 2013, pág. 107)

Allí se resalta la verdadera dimensión de la afectación, el perjuicio generado en la sociedad y la flagrante violación de los derechos humanos que esta práctica conlleva, utilizada generalmente por los grupos armados como fuente de financiación y de estrategia política de negociación, bajo esa premisa, Congresistas, Diputados, Militares, Policías, Campesinos, Civiles en general a lo largo de la historia han sufrido de esta conducta, la cual constituye una estrategia asimétrica de confortación (Restrepo J. , 2009).

Además de lo anterior, resulta imperante mencionar que en la legislación penal colombiana existe una diferenciación en relación con la toma de rehenes y el delito de secuestro, el primero, la toma de rehenes está contemplado en el artículo 148 y señala:

Artículo 148. Toma de rehenes. El que, con ocasión y en desarrollo de conflicto armado, prive a una persona de su libertad condicionando ésta o su seguridad a la satisfacción de exigencias formuladas a la otra parte, o la utilice como defensa, incurrirá en prisión de veinte (20) a treinta (30) años, multa de dos mil (2000) a cuatro mil (4.000) salarios mínimos legales mensuales vigentes, e inhabilitación para el ejercicio de derechos y funciones públicas de quince (15) a veinte (20) años (Senado, 2000).

Por su parte el secuestro en las dos modalidades (simple y extorsivo), señala dentro de la misma codificación:

Artículo 168. Secuestro simple. El que con propósitos distintos a los previstos en el artículo siguiente, arrebate, sustraiga, retenga u oculte a una persona, incurrirá en prisión de diez (10) a veinte (20) años y en multa de seiscientos (600) a mil (1.000) salarios mínimos legales mensuales vigentes.

Artículo 169. Secuestro extorsivo. El que arrebate, sustraiga, retenga u oculte a una persona con el propósito de exigir por su libertad un provecho o cualquier utilidad, o para que se haga $u$ omita algo, o con fines publicitarios o de carácter político, incurrirá en prisión de dieciocho (18) a veintiocho (28) años y multa de dos mil (2.000) a cuatro mil (4.000) salarios mínimos legales mensuales vigentes (Senado, 2000).

Configuración jurídico normativa que si bien es cierto implica para la víctima una restricción efectiva de su derecho a la libertad, movilidad y circulación, el delito de toma de rehenes se desarrolla con ocasión del conflicto armado.

Esta última conducta (toma de rehenes) al tenor de la Corte Constitucional constituye "un crimen de guerra, es decir, un comportamiento violatorio de los usos y costumbres aplicables 
durante situaciones de conflicto armado o, en otros términos, una flagrante vulneración de los principios y reglas que regulan la conducción de las hostilidades" (Sentencia C405, 2004).

Este crimen de guerra, (toma de rehenes), requiere según lo señala la Corte Constitucional la confluencia de unos requisitos:

(...) (a) la detención o retención de una o más personas (el o los rehenes), (b) la amenaza de asesinar, lesionar o continuar la retención del rehén, (c) con la intención de obligar a un tercero -que puede ser un Estado, una organización internacional, una persona natural o jurídica o un grupo de personas- a hacer o abstenerse de hacer un acto determinado, (d) como condición explícita o implícita para la liberación o la seguridad del rehén (Sentencia C291, 2007).

Partiendo de dicho criterio jurisprudencial, es dable asegurar que el delito de secuestro tiene una connotación diferentes en el derecho interno e internacional, puesto que su interés primarios está ligado a privar de la libertad a otra persona por motivos y razones distintas a las que confluyen en el conflicto armado, allí su principal distinción, si bien es cierto existen similitudes en cuento a la redacción, la diferencia la planeta el juez desde la perspectiva de la existencia de un conflicto armado interno o internacional.

\section{ANÁlisis DEL USO DE LA FUERZA DESDE LA PERSPECTIVA PENAL EN LOS CANI, UN PROBLEMA DE TIPICIDAD EN EL CONTEXTO COLOMBIANO}

Después de conocer las exigencias del DIH y la normatividad interna para establecer los distintos roles que se asumen en el contexto de una confrontación armada, los principios del Ius in Bellum y los distintos modos y medios de realizar un esfuerzo bélico en un conflicto asimétrico, es necesario ahora analizar las implicaciones jurídicas que puede traer el uso de la fuerza en el contexto de la confrontación armada, el cual si se analiza desde la perspectiva del marco jurídico que permite en desarrollo de las hostilidades, claramente se podría dilucidar de manera primigenia en sede de tipicidad.

La tipicidad como lo señala De la Cuesta (1995):

(...) es el primer elemento del delito, deriva del principio nullu crimen sine lege (principio de legalidad), que garantiza que solo las conductas previamente descritas en la ley penal como delitos serán castigadas con una pena (función de garantía). 
Se puede entender desde dos dimensiones, desde la perspectiva de la facultad que tiene el legislador en trasformar o construir comportamiento que afectan a la sociedad y que ameritan ser elevados a la categoría de delito (reserva legal) (Velásquez, 2010), desde la perspectiva del operador judicial, en donde la tipicidad constituye el proceso de valoración fáctica y jurídica que realiza este servidor, de un hecho que ha sido puesto a su conocimiento en la norma (Velásquez, 2010).

Desde esa perspectiva, el proceso de valoración de un hecho que se desarrolle en el contexto de un conflicto armado en Colombia, debe iniciar desde la materialización de un resultado, para efectos de la presente argumentación la muerte de un ser humano producida por unos miembros de la fuerza pública.

En ese contexto, cuando surge una investigación por la muerte de una persona en el desarrollo de las hostilidades, el Cuerpo Técnico de investigaciones de la Fiscalía (CTI) ingresa a la zona de los acontecimientos y realiza los actos urgentes de investigación, inspección a cadáver, recolección y embalaje de los elementos de prueba, actividades de vecindario, todo lo que dispone la Ley 906 de 2004, en relación con las diligencias que no requieren autorización judicial previa (Fiscalia, 2009).

Una vez cumplida esta actuación y de conformidad con lo señalado en el artículo 221 Constitucional y la Ley 1407 de 2010 (Código Penal Militar), el funcionario del CTI, debe enviar las diligencias la Juez de Instrucción Penal Militar para que inicie de conformidad con las competencias previstas en el artículo 116 y 250 constitucional la investigación por la muerte de esta persona.

Así lo reconoció el Consejo de Estado al resolver un acción de nulidad en relación con una acta suscrita entre el Ministerio de Defensa y la Fiscalía General de la Nación, donde de tajo se sustituyó la Constitución ya que se le asignaron funciones al fiscal de la URI, para dirimir conflictos de competencia, lo cual sin duda radica en el Concejo Superior de la Judicatura, en ese sentido señaló el alto tribunal:

(....) estima la Sala que de presentarse conductas delictivas por miembros de la Fuerza Pública, "con ocasión de las operaciones propias de las Fuerzas Militares", para determinar la competencia de la Justicia Penal Militar o de la Justicia ordinaria para conocer de un caso concreto, será el Juez de Instrucción Penal Militar quien al analizar la situación fáctica en que se 
cometió el acto delictivo confronte la conducta realizada y la operación o acción propios del servicio, para efecto de establecer si tal operación o acción se encuentra dentro del tipo de delito militar y del delito común adaptado a la función militar o se aparta de ella para tipificarse como conductas del conocimiento de la Justicia ordinaria (Consejo de Estado, 2012).

Aquello constituye el deber ser, lo cual difiere de la realidad pese al fallo del Concejo de Estado antes citado, ya que hoy por hoy, las diligencias aún continúan siendo enviadas de manera primigenia a la jurisdicción ordinaria, funcionario que si bien es cierto constituye la regla general, en muchos casos este servidor desconoce el quehacer diario operacional, el día a día militar y con ello algunas actuaciones según ejemplos desarrollados a lo largo de la presente argumentación pueden ser interpretada a la luz de un marco normativo inadecuado.

Pensemos por ejemplo en el resultado de una confrontación armada, un combate entre el Ejército y las FARC, en donde después de que termina las hostilidades las unidades realizan el registro respectivo de la zona de los acontecimientos y encuentran el cadáver de una persona cuyo deceso se produce como consecuencia de proyectiles de arma de fuego de carga única y de alta velocidad.

Los militares aseguran la escena para garantizar la cadena de custodia y la autenticidad de la evidencia, llegan los del CTI a cumplir la función antes reseñada y encuentran en poder de la persona abatida: un revolver calibre 38, un radio de comunicaciones, unas baterías 9 volteos y algunos estopines para cebar o activar explosivos.

Se realiza la actividad y todo el material es enviado al fiscal de la unidad de reacción inmediata territorial y allí se realiza una valoración preliminar, generalmente desde la perspectiva del marco normativo inadecuado, es decir teniendo en cuenta criterios jurídicos aplicables a situaciones de normalidad (DIDH), marco normativo que si bien es cierto confluye se complementan ${ }^{21}$ y no se excluye en una situación de conflicto armado, lo adecuado es acudir a la lex sepcialis, que para el caso concreto es el DIH. (Sentencia C084, 2016)

\footnotetext{
21 “(...) entre ambos cuerpos normativos -DIH y DIDH-, existe una concurrencia en su ámbito de aplicación material y personal, que hace que guarden la misma naturaleza en relación con los derechos que protegen, y que cuenten con similares mecanismos instituidos para garantizar dichos derechos, e inclusive en relación con las organizaciones internacionales que los promueven. Así, dentro de los múltiples pronunciamientos nacionales e internacionales- que señalan el carácter complementario y concurrente de ambos corpus de derechos humanos...." (Sentencia C084, 2016)
} 
Dicha aplicación inadecuada del marco jurídico, comporta por ejemplo realizar una valoración desde la proporcionalidad en la defensa y ataque aplicable a situaciones de normalidad, la institución de la legítima defensa por ejemplo salta a la luz jurídica y la igualdad de armas por supuesto opera en contra de los soldados que desarrollaron la confrontación armada.

Cuestionamientos como "lanzaron la proclama", "porque no lo capturaron", "ustedes tenían armas largas, granadas y el occiso tan solo un revolver", se coinvierten en piedras de tropiezo para la labor militar de quien adelantó el operativo, ya que su actuación prima facie lícita, se empieza a enlodar por argumentaciones que surgen de modelos jurídicos que prevén el uso de la fuerza como última alternativa, y termina siendo judicializado por un hecho que desde la perspectiva del DIH podría ser considerado atípico.

Última afirmación, que encuentra sustento en los principios del DIH previamente citados y en el pronunciamiento de la Corte que al respecto señala:

(...) que no se remite a duda que los Estados tienen derecho a perseguir a los grupos alzados en armas y que, por ello, la muerte en combate que la Fuerza Pública ocasione a los miembros de estos grupos insurgentes no constituye jurídicamente un "homicidio", y no es tipificada como una conducta punible. (Corte Constitucional, 2001)

La Corte Constitucional dispone que la muerte de un miembro de un Grupo Armado (combatiente en sentido genérico), un civil que participa directamente en las hostilidades, no es jurídicamente un homicidio, porque el Estado tiene el derecho a perseguir estas personas que hacen parte de los grupos alzados en armas, corresponde entonces al funcionario que analiza el asunto, determinar si los hechos guardan relación con el conflicto y se desarrollaron de la manera como fue presentado desde el mismo momento que culminó la confrontación armada.

Es atípica porque así lo plantea el DIH desde su normatividad, la actuación entonces está sustentada en la lex specialis, el uso legítimo de la fuerza como primera opción respecto de objetivos militares, tal y como lo plantea Olásola (2011):

(...) muerte y destrucción, incluso cuando afecta a civiles, son efectos inevitables de los conflictos armados, y no se encuentran prohibidos como tales por el Derecho Internacional 
Humanitario. Por tanto, de su existencia no se pude presumir sin más que se haya cometido un crimen de guerra. (Olasola, 2011).

Solo cuando muerte y destrucción son el resultado de infracciones graves del derecho internacional humanitario se puede hablar de responsabilidad penal individual.

En el mismo sentido la Corte Suprema de justicia señala:

(...) La imputación jurídica -u objetiva- existe si con su comportamiento el autor despliega una actividad riesgosa; va más allá del riesgo jurídicamente permitido o aprobado, con lo cual entra al terreno de lo jurídicamente desaprobado; y produce un resultado lesivo, siempre que exista vínculo causal entre los tres factores. Dicho de otra forma, a la asunción de la actividad peligrosa debe seguir la superación del riesgo legalmente admitido y a éste, en perfecta ilación, el suceso fatal. (Olasola, 2011, pág. 329)

Lo que sustenta la posibilidad de hacer uso de la fuerza en defensa de las instituciones, allí cobra sentido el papel del militar que ostenta el monopolio de las armas y por ello tiene la autorización de utilizarlas de manera legítima en contra de objetivos militares, con el fin de garantizar la continuidad del Estado, aplicar entonces el marco jurídico adecuado, además de ser un imperante moral, también es una obligación constitucional que surge del al reforma del artículo 221 de la Carta Magna

Aspecto que dentro del proceso de valoración de un caso concreto debe ser observado apreciado y analizado, esa es la instrucción enviada a los fiscales en todo el país en la Directiva 003 de 2015 donde se estipula:

- Las prácticas propias de los combates inmersos en conflictos armados implican necesariamente un exceso en las normas que prohíben matar o lesionar en un estado paz, esto es, cuando se mantiene la garantía de la seguridad general de los ciudadanos, en esta situación de conflicto representas actos propios del intercambio social. Aun dentro de esas prácticas es posibles reconocer reglas de juego claras que en su conjunto establecen un límite de tolerancia con el fin de mantener un mínimo de trato humanitario entre las partes.

(...)

- Dentro de ese sistema propio de derecho de la guerra se hallar, por tanto, normas de conducta que indican al combatiente las formas adecuadas de tratar a su adversario, de modo que el sentido mínimo de la humanidad se mantenga. Estas normas de conducta son la fuente que sirven para interpretar la tipicidad do atipicidad de la conducta dentro de ese sistema de derecho. En este sentido, se puede pensar que dentro de ese sistema especial del derecho de la guerra existe un "marco de permisión" de las conductas de los combatientes tan como de manera análoga la institución del riesgo permitido opera respecto de los posibles excesos en el ejercito de la libertad en un estado de paz (Fiscalia, 2015, pág. 24). 
Se reconoce entonces la posibilidad de hacer uso de la fuerza legítima, siempre y cuando la acción se de en el contexto de un conflicto armado respecto de combatientes en sentido genérico o personas que participan en las hostilidades mientras dure su participación, que difícil es hacer en ocasiones entender esa premia en los procesos judiciales ${ }^{22}$, en la práctica judicial es muy común encontrar argumentos que pretenden sustentar esta clase de resultados desde las perceptivas del artículo 32 de la ley 599 de 2000.

Abogados defensores utilizando criterios propios de sistemas normativos disímiles, (la institución de la legítima defensa o del estricto cumplimiento de un deber legal), si bien es cierto no se oponen a los resultados que reúnan las condiciones objetivas del conflicto armado, llenan de dificultad la argumentación, ya que una cosa en la proporcionalidad en materia de DIH y otro muy diferente en el contexto de una situación de normalidad en el marco del DIDH.

Partiendo entonces del contexto del DIH, la valoración de cara a determinar la criminalización de una infracción a este cuerpo normativo, surge del análisis de la planeación y ejecución de la operación que permitió el resultado antijurídico.

Cuando en el seno de la fuerza miliar se planea una operación militar solo podrá hacerse uso de la fuerza directa o como primera opción si el marco jurídico previsto para la operación es el DIH, en caso que la operación prevea una actuación diferente por ejemplo la captura de un delincuente común, el uso de la fuerza solo se puede aplicar en caso de legítima defensa (Manual FFMM, 2015).

Lo anterior porque existen unas operaciones que son ofensivas donde el marco jurídico aplicable siempre va a ser el derecho de la guerra, la ventaja militar, el principio de distinción, la proporcionalidad y la necesidad militar, son los ejes temáticos que se observan cuando se adelanta el proceso militar de la toma de decisiones, es decir, desde la etapa de la planeación se puede concebir el uso de la fuerza letal, así la ejecución tendrá las garantías necesarias para que se pueda ejecutar la acción, el hombre que desarrolla lo pretendido por su comandante desde su intensión en la misión, está cubierta por el manto de la legalidad, lo anterior porque

\footnotetext{
${ }^{22}$ Se hace esta aseveración partiendo del conocimiento privado como Juez de la República, durante los años de experiencia que he tenido en el desempeño de mi función he podido analizar esta clase de situaciones.
} 
las ordenes de operaciones se consideran actos administrativos complejos y su legalidad se debe presumir, aquellas van mucho más allá de los actos de combate (FFMM, 2010).

Ese argumento queda ratificado por la Corte Constitucional al señalar dentro del proceso de valoración de las conductas constitutivas de instrucciones al Derecho Internacional Humanitario:

(...) El nexo con el conflicto armado, ha sido interpretado como la relación estrecha del crimen con las hostilidades, es decir, que el conflicto armado debe jugar un rol sustancial en la decisión del perpetrador, en su habilidad para cometer el crimen o en la manera como la conducta fue finalmente cometida. En consecuencia, el elemento sistemático implica la existencia de un nexo del crimen con el conflicto armado, lo cual además es absolutamente coherente con lo señalado en el propio Acto Legislativo, pues este solamente se aplica respecto de hechos cometidos en este contexto, tal como señala el parágrafo $2^{\circ}$ : "En ningún caso se podrán aplicar instrumentos de justicia transicional a grupos armados al margen de la ley que no hayan sido parte en el conflicto armado interno, ni a cualquier miembro de un grupo armado que una vez desmovilizado siga delinquiendo" (Sentencia C79, 2013)

Porque en la ejecución de las operaciones ofensivas, está implícito el uso de la fuerza letal, ello es licito, aceptado por el marco normativo del DIH, lo cual si bien es cierto permite como lo dice la Corte Constitucional en la sentencia C177 de 2001, causar muertes sin que ello constituya jurídicamente un homicidio, los principios de la guerra como la precaución, distinción, proporcionalidad, son el límite de actuación sin el cual el resultado se tornó espurio, ilegal, ilegítimo.

Entender el papel que cumple el militar y la doctrina operacional, resulta ser entonces el ideal dentro del proceso judicial, el fuero militar entonces, que es concebido como una prerrogativa, “en virtud de la cual los miembros de las Fuerzas Militares y de la Policía Nacional e $\mathrm{n}$ servicio activo no son investigados y juzgados por los físcales y jueces a los cuales están sometidos la generalidad de los ciudadanos, sino por jueces y tribunales militares, con arreglo al Código y leyes penales militares, en aquellos eventos en los que incurren en conductas punibles al ejecutar o desarrollar sus funciones legales y constitucionales" (Sentencia C084, 2016).

Permite acoger este tipo de actuaciones en el seno de la justicia penal militar, la cual está conformada por servidores probos, capacitados, entrenados, conocedores no solamente de los aspectos jurídicos sino operacionales, elementos esencial que permito precisamente la reforma 
del artículo 221 constitucional, obligar a la capacitaciones de los operadores judiciales en temas propios del DIH, sin duda muestra una realidad enmascarada en la injusticia y el sesgo ideológico.

Esta competencia excepcional atribuida a la jurisdicción penal militar, tiene su fundamento a partir del precepto constitucional consagrado en el artículo 221 que señala: "De los delitos cometidos por los miembros de la Fuerza Pública en servicio activo, y en relación con el mismo servicio, conocerán las Cortes Marciales o Tribunales Militares, con arreglo a las prescripciones del Código Penal Militar...”. Una primera interpretación que ha de hacerse, es que la jurisdicción penal militar tiene competencia para investigar y juzgar tanto los delitos militares, como los delitos comunes.

Sobre los delitos comunes como el homicidio, ese mandato constitucional estableció dos presupuestos i) uno subjetivo que se extrae al evidenciar que el imputado al momento de la ocurrencia de los hechos era miembro activo de la Fuerza Pública, y ii) otro elemento de carácter funcional cuando el delito investigado guarda una relación con el servicio (Sentencia C084, 2016).

Dicha relación con el servicio, surge además de los contenidos previsto en la sentencia C358 de (1997), de la valoración de tres elementos incluidos en la jurisprudencial del Consejo Superior de la Judicatura, presunción de legalidad de la actuación, presunción de conexidad con el servicio y presunción de inocencia del servidor.

Los tres íntimamente ligados al concepto de derecho operacional, que incluye todas las actuaciones que se desarrollan desde la etapa primigenia, previa, preliminar al desarrollo de la confortación. La misión que surge de la legitimidad de quien tiene atribuciones de comando, justifica la presencia de la unidad militar en el teatro de los acontecimientos, esa valoración previa y posterior, permiten contribuir en la interpretación del resultado y su ilación tanto con la posibilidad jurídica del uso dela fuerza, como con el contexto mismo del conflicto.

Allí, se activa el DIH como fuente esencial de interpretación de la actuación del servidor comprometido en los hechos y permite al Juez de Instrucción Penal Militar que está llamado a interpretar la acción de sus pares, determinar si el contexto en el cual se desarrollaron los hechos cumplen con los presupuesto normativos jurisprudenciales y legales necesarios para 
cumplir con las exigencias de las costumbres de la guerra, o si por el contrario se configura una conducta ilegal, en cuyo caso perderá la competencia y la investigación deberá ser enviada a la justicia ordinaria (Consejo de Estado, 2012).

Se tiene entonces una investigación que debe ser activar en caso de que se utilice la fuerza en desarrollo de una operación militar, esta actuación debe iniciar en el seno de la justicia penal militar, la actuación de la fuerza militar se presume licita no al revés, incluso el resultado muerte es una opción en el contexto del DIH, es un problema de tipicidad.

Si la muerte en combate, se desarrolla en el contexto de las actuaciones permitidas y toleradas por el DIH, esta vulneración al bien jurídico no es típica, el marco de valoración de la conducta que realiza el operador debe descansar en sede de tipicidad, el marco aplicable de interpretación del resultado es el derecho legítimo de la guerra, así se materializa la seguridad jurídica de los soldados y policías que cumplen su función en las regiones del territorio nacional, así se da cumplimiento a la reforma constitucional del artículo 221 (ato legislativo No 1 de 2015), así se garantiza la aplicación de una justicia pronta proba y adecuada para los que históricamente siempre han estado prestos a entregar su vida en defensa del pueblo colombiano. 


\section{CONCLUSIONES}

Los combatientes en los conflictos armados internaciones, tienen derecho a realizar acciones ofensivas en contra de sus adversarios, pueden hacer uso de la fuerza legítima si contra quien dirigen el ataque resulta ser un objetivo militar, respetando para tal fin las normas de la guerra, con el fin de minimizar las consecuencias de las hostilidades, dejando a un lado y lejos de la confrontación armada a la población civil quien es protegida de ataques directos en el entorno normativo del Derecho Internacional Humanitario.

Estos combatientes, tiene el estatus de prisioneros de guerra en caso de ser capturados, lo que implica el respeto por su dignidad humana, ello legitima la actuación en el campo de combate y permite humanizar las guerras, dicha prerrogativa no la tienen los miembros de los grupos armado en los conflictos de carácter interno, en caso de una violación de la ley deben ser investigados, judicializados y castigados si el caso por la infracción al derecho aplicable en el país donde se desarrollen las hostilidades.

Existe la posibilidad de participación de personas que si bien es cierto son civiles, hacen parte directa de las hostilidades y por ello pierden su protección frente a ataques directos, para tal fin se debe acudir a la doctrina internacional del CICR, el cual reconoce la existencia de tres requisitos acumulativos (umbral de daño, nexo beligerante, causalidad directa), que deben confluir en un caso concreto para poder considerar a esta personas como miembros activos de la hostilidad en cuyo caso es dable hacer uso de la fuerza siempre y cuando se respecten el marco normativo del DIH.

También en el desarrollo de las hostilidades, aparecen personas civiles que participan indirectamente en las hostilidades, las cuales en la dinámica del conflicto pueden prestar una ayuda anterior, concomitante o posterior, frente a ellos, no es dable hacer uso de la fuerza de manera directa, el tratamiento es asimilable a los delincuentes comunes, es decir el contexto del DIDH, la normatividad interna, la judicialización y la captura son las alternativas que permiten confrontar su accionar y reprimir su apoyo o contribución. 
Además de lo anterior, para determinar si se aplica o no el DIH en un caso concreto, es indispensable establecer si el caso objeto de estudio se reúnen las condiciones objetivas del conflicto armado.

Para poder determinar esa condición, la legislación nacional interna y las decisiones de los Tribunales Internacionales de Justicia, son los principales instrumentos que debe tener en cuenta el operador judicial ya que como se pudo evidenciar, determinar la existencia de un conflicto no depende de la denominación que en ese sentido dé el gobierno de turno, depende entonces de la valoración del umbral de violencia y de los elementos contentivos en los instrumentos ante citados.

Determinar la existencia del conflicto armado, permite la observancia, aplicación y respecto de los principios del $\mathrm{DIH}$, los cuales contribuyen a mantener alejados de las consecuencias de las hostilidades a la población civil y reducir los efectos de las acciones bélicas.

Desafortunadamente, en el contexto de un conflicto asimétrico, algunos métodos no permiten distinguir entre población civil y combatientes en sentido genérico dando alcance a la decisión de la Corte ya evidenciada (C291/2007), las minas, los AEI, la utilización de menores en las hostilidades y la privación arbitraria de la libertad, constituye una flagrante ofensa a estos principios que se construyen con base en la costumbre internacional.

Estos métodos ilegales, han sido la forma en la cual los grupos armados han podido continuar en el desarrollo de su actuación a lo largo de tiempo, especialmente por la desigualdad de armas que tienen en relación con los ejércitos regulares, han encontrado entonces en estos métodos no convencionales, la posibilidad de equiparar las cargas y continuar con su plataforma de lucha.

Métodos solo entendibles en el contexto del derecho operacional, en el cual se concibe la posibilidad de privar de la vida a un ser humano por parte del Estado y de aquellos que ostentan el monopolio de las armas en defensa legítima de las instituciones, entender esta dinámica resulta complejo, cuando el encargado del análisis no aplica el marco jurídico correspondiente, así la muerte de una persona que participa directamente en las hostilidades, no es jurídicamente un homicidio. 
El estudio de la conducta punible surge en sede de tipicidad y se puede resolver con un archivo, cuando las condiciones objetivas previstas en el análisis ya desarrollado, justifica la actuación del militar con base en derecho legítimo de hacer uso de la fuerza en contra de aquellos que atentan contra la institucionalidad y siembra de terror los campos y ciudades como estrategia para alcanzar la toma del poder.

Para esto, el operador judicial debe tener herramientas jurídicas y entendimiento claro de los manuales de operaciones de las Fuerzas Militares, lo que se ha explicado de manera clara, para así establecer cuando, con base en los lineamientos que inclusive la Fiscalía General de la Nación ha adoptado, se encuentra bajo una baja en combate conforme a las reglas del DIH o contrario a esto, una infracción a sus principios.

No sólo basta entonces con analizar el contexto ocasional en que se desarrolló la muerte en combate, sino además, el operador judicial debe conocer la labor que cumplía en el objetivo militar y eso lo logra además, con la ayuda de los diferentes medios probatorios, lo cuales le servirán para determinar si se trataba o no de un combatiente y su grado de participación en el conflicto, aspectos que además resultan indispensables para la administración de justicia, máxime cuando se está ad portas de la implementación de una justicia transicional (Acto legislativo No 1 de 2017) para poner fin al conflicto con las FARC. 


\section{REFERENCIAS}

Henckaerts, J.-M. (2005). Estudio sobre el derecho internacional humanitario consuetudinario: una contribución a la comprensión y. Revista Internacional del Cruz Roja, 175-212. Obtenido de http://www.observatoriodih.org/_pdf/principios_dih.pdf

Acevedo, O. (2016). El corazón de las víctimas: Aportes a la verdad para la reconciliación en Colombia. Bogotá D.C.: Banco de la República.

Acosta, P. (2005). La persona ante la Corte Interamericana de Derechos Humanos. Bogota D.C.: Universidad Externado de Colombia.

Aguirre, M. (2002). De Nueva York a Kabul. New York: CPI.

Alcadia de Bogota. (2012). ACTO LEGISLATIVO 01 DE 2012. Obtenido de http://www.alcaldiabogota.gov.co/sisjur/normas/Norma1.jsp?i=48679

Amnistía Internacional. (2008). Infome estado de los derechos humanos en el mundo. Londres: Amnistía Internacional.

Anaya, A. (2005). Glosario de términos básicos sobre derechos humanos. Mexico: Universidad Ibeoramericana.

Ayala , J. A. (2007). Curso en Derecho Internacional de los Conflcitos Armados y Derecho Penal Internacional. Buicaramanga: Imprenta Militar.

Barja, J. (2004). El principio non bis in idem. Madrid: Dikinson.

Beltran, J. (2005). LA OBJECION DE CONCIENCIA DE LOS PROFESIONALES SANITARIOS. Revista de la Cruz Roja Española, 63 -72.

Bondia, D. (2009). Victimas invisibles, conflicto armado y resistencia civil en Colombia. Madrid: Huygens.

Burger, J. (2000). El derecho internacional humanitario y la crisis de Kosovo: lecciones aprendidas y por aprender. Revista Internacional de la Cruz Roja. Obtenido de https://www.icrc.org/spa/resources/documents/misc/5tdny5.htm

Caracol TV. (15 de Mayo de 2015). Conmoción en Cauca por muerte de niña a causa de una mina antipersona. Obtenido de http://noticias.caracoltv.com/colombia/conmocion-encauca-por-muerte-de-nina-causa-de-una-mina-antipersona

Centro Nacional de Memoria Histórica. (2013). Una Sociedad Secuetrada. Bogota: Imprenta Nacional. Obtenido de 
http://www.centrodememoriahistorica.gov.co/descargas/informes2013/secuestro/socie dad-secuestrada.pdf

Chornet, C. (2006). Uso de la fuerza y protección de los derechos humanos en un nuevo orden internacional. Valencia: Tirant Lo Blanch.

CICR. (17 de Ocubre de 1907). Reglamento relativo a las leyes y costumbres de la guerra terrestre (H.IV.R). Haya. Obtenido de https://www.icrc.org/spa/resources/documents/misc/treaty-1907-regulations-lawscustoms-war-on-land-5tdm39.htm

CICR. (8 de Junio de 1977). Protocolo I adicional a los Convenios de Ginebra de 1949 relativo a la protección de las víctimas de los conflictos armados internacionales, 1977. Ginebra. Obtenido de https://www.icrc.org/spa/resources/documents/misc/protocoloi.htm\#9

CICR. (1997). Convención de 1997 sobre la prohibición de las minas antipersonal y sobre su destrucción. Obtenido de https://www.icrc.org/spa/assets/files/other/1997_minas.pdf

CICR. (29 de Octubre de 2010). Jus ad bellum y jus in bello. Ginebra. Obtenido de https://www.icrc.org/spa/war-and-law/ihl-other-legal-regmies/jus-in-bello-jus-adbellum/overview-jus-ad-bellum-jus-in-bello.htm

CICR. (2010). Los Convenios de Ginebra de 1949 y sus Protocolos adicionales. Ginebra: Comite Internacional de la Cruz Roja. Obtenido de https://www.icrc.org/spa/war-andlaw/treaties-customary-law/geneva-conventions/overview-geneva-conventions.htm

CICR. (2011). Métodos y medios de guerra. Obtenido de https://www.icrc.org/spa/war-andlaw/conduct-hostilities/methods-means-warfare/overview-methods-and-means-ofwarfare.htm

CIDH, caso de la Masacre de Plan de Sánchez Vs el Estado de Guatemala (Corte Interamericada de Derechos Humanos 29 de Abril de 2004). Obtenido de http://www.corteidh.or.cr/docs/casos/articulos/seriec_105_esp.pdf

Comisión. (22 de Octubre de 2002). Informe Sobre Terrorismo Y Derechos Humano. Wachintong. Obtenido de https://www.cidh.oas.org/PRIVADAS/terrorismo.htm

Comisión Interamericana. (1999). Tercer Informe sobre la situación de Derechos Humanos en Colombia. Bogota.

Consejo de Estado, Expedientes acumulados núms. 2009-00196 y 2008-00025-00. (Consejo de Estado 15 de noviembre de 2012).

Contreras, J. (1989). Régimen jurídico de la asistencia religiosa a las fuerzas armadas en el sistema Español. Madrid: Ministerio de justicia - Centro de Publicaciones. 
CPI. (2016). Esatuto de Roma. Obtenido de

http://www.un.org/spanish/law/icc/statute/spanish/rome_statute(s).pdf

De Mare, K. C. (12 de Agosto de 2016). Observatorio de D.I.H. Obtenido de http://www.observatoriodih.org/_pdf/principios_dih.pdf

DFAE. (2014). El ABC del Derecho Internacional Humanitario. Berna. Obtenido de https://www.eda.admin.ch/dam/eda/es/documents/publications/GlossarezurAussenpolit ik/ABC-Humanitaeren-Voelkerrechts_es.pdf

Doménech, J. L. (2003). Estatuto y trato de los combatientes en caso de captura. "Derecho internacional humanitario y temas de áreas vinculadas", Lecciones y Ensayos nro. 78, 133 - 164. Obtenido de https://www.icrc.org/spa/assets/files/other/05_domenech.pdf

El tiempo. (16 de Septiembre de 2016). Gobierno lamentó muerte de niño que cayó en mina antipersona. El tiempo.com. Obtenido de http://www.eltiempo.com/colombia/otrasciudades/minas-antipersona-en-huila/16712564

FFMM. (2010). Manual del Proceso Militar de la Toma de Decisiones. Obtenido de http://biblioteca.sivec.espe.edu.ec/upload/Manual_PMTD.pdf

Fiscalia. (2009). Manual de Procedimientos de Fiscalía en el sistema penal acusatorio Colombiano. Obtenido de http://www.fiscalia.gov.co/en/wpcontent/uploads/2012/03/spoa.pdf

Fiscalia. (2015). Directiva 003 de 2015. Bogota D.C.

GALEON.COM. (12 de Julio de 2016). ¿Que es una mina antipersonal? doi:http://www.sinminascolombia.galeon.com/productos1686738.html

Galisoga, A. (2013). El conflicto de Iraq y el Derecho Internacional. El caso Couso. Santiago de Compostela: Universidad de Santiago de Compostela.

Giraldo, J. (2009). Guerra civil posmoderna. Bogota D.C.: Siglo del hombre editores.

Guévara, J. (2004). México frente al derecho internacional humanitario. México: Universidad Iberoamericana.

Guisández, J. (2007). El principio de proporcionalidad y los daños colaterales, un enfoque pragmàtico. Bogota: Bibliotega juridica Dike.

Gutiérrez, H. (2014). Elementos de Derecho Internacional Humanitario. Buenos Aires: Universidad de Buenos Aires.

Huertas, O. (2008). Formación en derecho internacional humanitario: aproximaciones para su comprensión. Bogota D.C.: Corporación de Juristas Siglo XXI. 
Imagenes tomadas de El pais.com. (2008). Encuentran 'fábrica' de explosivos de las Farc.

Obtenido de http://historico.elpais.com.co/paisonline/notas/Mayo052008/tacucos.html

Kai Ambos. (2008). El marco jurídico de la justicia de transición. Bogota D.C.: Temis S.A.

Manual FFMM. (2015). Manuel de derecho Operacional Fuerzas Miliatres de Colombia. Bogota.

Manual Fuerzas Armadas Perú. (2010). Manual Para Las Fuerzas Armadas. Lima. Obtenido de https://www.mindef.gob.pe/informacion/documentos/manual_ddhh_ffaa_2010.pdf

Manual Operacional Ecuador. (2014). Manual de derecho en las operaciones militares. Quito. Obtenido de http://www.coed.mil.ec/archivos_coed/MANUAL\%20DE\%20DERECHO\%20EN\%20 LAS\%20OPERACIONES\%20MILITARES.pdf

Marín. (2016).

Mejia A, J. C., Mejia O, J., Cote, G., \& Cardenas, A. (2009). Formacion especializada en DIH y DIDH. Bogota: Imprenta Nacional.

Mejia, J. (2009). Sin eufenismos, Conflicto y Paz en Colombia. Bogota D.C.: Temis S.A.

Mejia, J. C. (2010). Aplicación de los principios del DIH a los tipos penales consagrados en el Título II del Código Penal y al artículo 48 del Código Único Disciplinario. Bogota: Ediprime Ltda.

Melzer, N. (2010). Guía para interpretar la noción de participación directa en las hostilidades según el Derecho Internacional Humanitario. Comité Internacional de la Cruz Roja.

Ministerio de Defensa. (22 de abril de 2016). Directiva 015. Expedir Los Lineamientos Del Ministerio De Defensa Nacional Para Caracterizar Y Enfrentar A Los Grupos Armados Organizados (GAO).

Montoya, C. (23 de abril de 2012). Impresionante relato de un niño que entró a las Farc a los 12 años y se fugó a los 17. El pais.com.co. Obtenido de http://www.elpais.com.co/elpais/judicial/noticias/impresionante-relato-nino-entro-farc12-anos-y-fugo-17

Nieto, A. (2009). El derecho penal entre la guerra y la paz. Cuenca: Ediciones de la Universidad de Castilla - la Mancha.

Noticias RCN. (15 de Julio de 2015). Soldado murió al activar una mina durante operativo de desminado en Antioquia. Obtenido de http://www.noticiasren.com/nacionalpais/soldado-murio-al-activar-una-mina-durante-operativo-desminado-antioquia 
Oficina del Alto Comisionado de las Naciones Unidas para Colombia. (2014). Bogotá.

Olasola, H. (2011). Ensayos de derecho penal internacional. (B. J. DIKE, Ed.) Bogotá: Pontifica Universidad Javeriana.

ONU. (30 de junio de 2003). Comunicado de Prensa. Sobre la Importancia del Principio Humanitario de Distinción en el Conflicto Armado Interno. Bogota. Obtenido de http://www.hchr.org.co/publico/comunicados/2003/cp0313.pdf

Pinto, M. (2003). La nocion de conflicto armado en la jurisprudencia del Tribunal Penal Internacional para la ex-Yuguslavia*. Derecho internacional humanitario y temas de áreas vinculadas", Lecciones y Ensayos nro. 78, 297 - 310. Obtenido de https://www.icrc.org/spa/assets/files/other/11_la_nocion_de_conflicto_armado.pdf

Procuraduría. (2010). Directiva 016. Obtenido de http://www.procuraduria.gov.co/portal/media/file/descargas/delegadas/disciplinaria\%2 0ddhh/Directiva\%20016\%20de\%202010.pdf

Protocolo I. (1949). Obtenido de https://www.icrc.org/spa/resources/documents/misc/protocolo-i.htm\#12

RAE. (15 de agosto de 2016). Madrid. Obtenido de http://dle.rae.es/?id=9tUMoFe

Ramelli, A. (1999). Derecho internacional humanitario y estado de beligerancia. Bogotá D.C.: Universidad Externado de Colombia.

Restrepo, J. (2009). Guerra y violencias en Colombia: herramientas e interpretaciones. Bogota D.C.: Universidad Pontificia Javeriana .

Restrepo, L. (2005). Conflcito Armado o amenaza terrorista. Bogota: Academia nacional de medicina.

Rey, F. (2007). La universalidad cuestionada: debates humanitarios en el mundo actual. Bogotá D.C.: Instituto de estudios sobre el conflcto.

Rogers, M. P. (1999). Modelo de Manual acerca del derecho de los conflictos armados. Ginebra: CICR.

Salazar, A., \& Jaramillo, A. (1992). Medellín: las subculturas del narcotráfico. Medellín: CINEP.

Sánchez, R. (2011). ¿Hay o no conflicto armado en Colombia? . Ámbito jurídico.

Santacruz, R. (2011). El Reclutamiento de Menores en El Conflicto Armado Interno Colombiano. Bogota D.C.: Editorial Academica Espanola. 
Sarache, C. A. (2014). Criterios para identificar que constituye un "Blanco Legítimo" a la luz de las normas del Derecho Internacional Humanitario. Revista Especializada de Justicia Penal Militar, 54-57.

Segura, A. (2007). El derecho internacional humanitario y las operaciones de mantenimiento de la paz de las naciones unidas. México: Plaza y Valdez Editores.

Semana. (2014). Colombia, el triste líder en víctimas por minas. Semana.com. Obtenido de http://www.semana.com/nacion/articulo/colombia-el-pais-con-mas-victimas-porminas-antipersonal/382454-3

Senado. (2000). Ley 599. Obtenido de http://www.secretariasenado.gov.co/senado/basedoc/ley_0599_2000_pr005.html\#162

Senado. (2005). Ley 975 de Justicia y Paz. Obtenido de http://www.secretariasenado.gov.co/senado/basedoc/ley_0975_2005.html

Senado. (2011). Ley 1448. or la cual se dictan medidas de atención, asistencia y reparación integral a las víctimas del conflicto armado interno y se dictan otras disposiciones. Obtenido de http://www.secretariasenado.gov.co/senado/basedoc/ley_1448_2011.html

Senado. (2015). Acto elgislativo No 01. Reforma el artículo 221 de la Constitución Política de Colombia. Obtenido de http://www.secretariasenado.gov.co/senado/basedoc/acto_legislativo_01_2015.html

Sentencia C084 (Corte Constitucional febrero de 24 de 2016). Obtenido de http://www.corteconstitucional.gov.co/relatoria/2016/C-084-16.htm

Sentencia C084 (Corte Constitucional 24 de Febrero de 2016). Obtenido de http://www.corteconstitucional.gov.co/relatoria/2016/C-084-16.htm

Sentencia C084 (Corte Constitucional 24 de febrero de 2016). Obtenido de http://www.corteconstitucional.gov.co/relatoria/2016/C-084-16.htm

Sentencia C177. (2001).

Sentencia C225 (Corte Constitucional 18 de Mayo de 1995). Obtenido de http://www.corteconstitucional.gov.co/relatoria/1995/C-225-95.htm

Sentencia C240 (Corte Constitucional 1 de Abril de 2009). Obtenido de http://www.secretariasenado.gov.co/senado/basedoc/c-240_2009.html\#1

Sentencia C240 (Corte Constitucional 1 de abril de 2009). Obtenido de http://www.corteconstitucional.gov.co/RELATORIA/2009/C-240-09.htm

Sentencia C291 (Corte Constitucional 25 de abril de 2007). Obtenido de http://www.corteconstitucional.gov.co/relatoria/2007/C-291-07.htm 
Sentencia C388 (Corte Cosntitucional 25 de junio de 2014). Obtenido de http://www.corteconstitucional.gov.co/RELATORIA/2014/C-388-14.htm

Sentencia C405 (Corte Constitucional 2004). Obtenido de http://www.corteconstitucional.gov.co/RELATORIA/2004/C-405-04.htm

Sentencia C79 (Corte Constitucional 28 de Agosto de 2013). Obtenido de http://www.corteconstitucional.gov.co/relatoria/2013/C-579-13.htm

Sentencia Casación 14225 (Corte Suprema de Justicia 10 de 05 de 2010). Obtenido de http://www.cortesuprema.gov.co/corte/wpcontent/uploads/relatorias/pe/bloct2016/SP14205-2016.pdf

Sentencia Casacion, 20676 (Corte Suprema de Justicia 02 de Septiembre de 2006).

Sentencia Corte Suprema, 11837 (Corte Suprema de Justicia 4 de Febrero de 1999).

Sentencia Corte Suprema, 29753 (Corte Suprema de Justicia 27 de Enero de 2010).

Sentencia T260 (Corte Constitucional 29 de marzo de 2012). Obtenido de http://www.corteconstitucional.gov.co/relatoria/2012/T-260-12.HTM

Serrano, T. (2014). El homicidio en persona protegida. Bogota D.C.: Temis.

Setencia C 160 (Corte Constitucional 1998). Obtenido de http://ciruelo.uninorte.edu.co/pdf/derecho/28/11_Postura\%20de\%201a\%20corte.pdf

Setencia TIPR, Fiscal vs. Rutaganda (Tribunal Penal Internacional para Ruanda 6 de diciembre de 1999). Obtenido de http://www.corteconstitucional.gov.co/relatoria/2007/C-291-07.htm\#_ftn37

TIPY, Fiscal Vs Stalislav Galic (Tribunal Penal Internacional para la Antigua Yugoslavia 5 de Diciembre de 2003).

TIPY, Fiscal vs. Fatmir Limaj y otros, (Tribunal Internacional para la Antigua Yugoslavia 30 de Noviembre de 2005). Obtenido de http://www.corteconstitucional.gov.co/relatoria/2007/C-291-07.htm\#_ftn37

TIPY, Caso del Fiscal vs. Fatmir Limaj y otros (Tribunal Internacional para la Antigua Yugoslavia 30 de Noviembre de 2005). Obtenido de http://www.corteconstitucional.gov.co/relatoria/2007/C-291-07.htm\#_ftn37

UNICEF. (2012). La Niñez en el Conflicto Armado Colombiano. Bogota. Obtenido de https://www.unicef.org/colombia/pdf/boletin-8.pdf

Valencia, A. (1991). La humanización de la guerra: derecho internacional humanitario y conflicto armado en Colombia. Bogotá D.C.: Universidad de los Andes. 
Velásquez, F. (2010). Manual de derecho Penal parte general. Bogota D.C.: Ediciones Jurídicas Andrés Morales.

Verdad Abierta. (2015). Reclutamiento de niños. Verdad Abierta.com. Obtenido de http://www.verdadabierta.com/reclutamiento-de-ninos

Vicepresidencia. (2010). FORMACIÓN ESPECIALIZADA EN INVESTIGACIÓN, JUZGAMIENTO Y SANCIÓN DE VIOLACIONES A LOS DERECHOS HUMANOS E INFRACCIONES AL DERECHO INTERNACIONAL HUMANITARIO. Bogota.

Villarraga, Á. (1998). Derecho internacional humanitario aplicado: los casos de Colombia, Guatemala, El Salvador, Yugoslavia y Ruanda : memorias del Seminario internacional "Realidad y perspectivas del derecho internacional humanitario". Bogota D.C.: Oficina del Alto Comicionado para la Paz - Imprenta Nacional. 